\title{
Jesuits in the North American Colonies and the United States
}

Faith, Conflict, Adaptation

\author{
Catherine O'Donnell \\ Arizona State University, Tempe, USA \\ codonnell@asu.edu
}

\begin{abstract}
From Eusebio Kino to Daniel Berrigan, and from colonial New England to contemporary Seattle, Jesuits have built and disrupted institutions in ways that have fundamentally shaped the Catholic Church and American society. As Catherine O'Donnell demonstrates, Jesuits in French, Spanish, and British colonies were both evangelists and agents of empire. John Carroll envisioned an American church integrated with Protestant neighbors during the early years of the republic; nineteenth-century Jesuits, many of them immigrants, rejected Carroll's ethos and created a distinct Catholic infrastructure of schools, colleges, and allegiances. The twentieth century involved Jesuits first in American war efforts and papal critiques of modernity, and then (in accord with the leadership of John Courtney Murray and Pedro Arrupe) in a rethinking of their relationship to modernity, to other faiths, and to earthly injustice. O'Donnell's narrative concludes with a brief discussion of Jesuits' declining numbers, as well as their response to their slaveholding past and involvement in clerical sexual abuse.
\end{abstract}

\section{Keywords}

Jesuits - Society of Jesus - American colonies - United States - Catholic schools Catholic higher education - Vatican II - Jesuit slaveholding - John Carroll - Pierre-Jean De Smet 
Members of the Society of Jesus first set foot on land that would become part of the United States in the earliest days of European colonization. In the years that followed, Jesuits explored territory, proselytized indigenous peoples, and participated in Spanish, French, and English imperialism in ways that shaped both local and transatlantic communities. In the eighteenth century, the order ran afoul of European sovereigns. After first facing banishment from particular realms, in 1773 the Society was suppressed by Pope Clement XIV (1705-74, r.1769-74). Yet, Jesuits remained a part of the history of the American church even when they did not, in the view of the church, exist. The Jesuit who would become the first bishop and archbishop in the United States, John Carroll $\left(1735^{-1815}\right)$, drew on his formation in the Society and on his brethren's advice as he knit Catholicism into the revolutionary and early national United States. And although only a handful of former Jesuits remained when the order was restored, their numbers and influence grew rapidly. Within twenty years, Jesuits confidently participated in arguments over the role of Catholics and of religion itself in the United States, and they began to create an educational network that stretched the length and breadth of the nation.

Throughout much of the nineteenth century, members of the restored Society saw themselves as defenders of tradition and orthodoxy against the "corrosions" of modernity, repudiating the pragmatic accommodations that had often characterized Jesuits' work throughout the globe. In the twentieth century, Jesuits again began to collaborate with a range of cultural, political, and religious actors as they worked to extend the reach of the church as they understood it. The Second World War, the postwar era, and the Second Vatican Council (1962-65) brought dramatic transformation. Some Jesuits embraced the changes and remade the order from within. Many others left. Their departure and the declining number of young men beginning Jesuit formation means that Jesuits have needed in recent years once again to rethink their role in the world and the nature of their community.

Across the centuries, American Jesuits have been a small group-some eight thousand members at their peak, usually far fewer-and one mistrusted by many of their countrymen. Yet, American history is incomplete without attention to their labors. Jesuits, for their part, cannot be understood without exploration of the imperial, national, and cultural histories in which they have participated as individuals and as an order. 
In 1521, a cannonball shattered the leg of a Basque nobleman named Ignatius of Loyola (c.1491-1556) and sent his life-and in no small measure the history of the Catholic Church — on a new course. While Ignatius endured painful and unsuccessful operations, he read the Life of Christ by Ludolf of Saxony (1300-78), a popular work that told the story of Jesus and urged readers to imagine themselves within its scenes; he also devoured The Golden Legend, a vivid compendium of martyrs, miracle workers, and the competing faiths they sought to vanquish. Realizing that the thought of life as a courtier and knight now left him unhappy, and that the prospect of following in the path of saints brought him joy, Ignatius made his decision. After a pilgrimage to the Holy Land, he enrolled in the University of Paris, where he drew to himself other men who shared his vision of "a brotherhood of Jesus." In the spring of 1539, a small group gathered in Rome and submitted their "plan of life" for approval to the Holy See. In 1540, the Society of Jesus was born.

Chosen the Society's first superior general in April 1541, Ignatius created Constitutions in which he limned its rules and forms as well as identifying qualities required of its leaders. They were promulgated only in 1558, after his death. In 1548, he also published the Spiritual Exercises, which, although composed before the Society's foundation, became a manual intended to teach-and, because the book was to be a lifelong companion for Jesuits, to reteach-its users to live in prayer and intimacy with God. Historian John O'Malley calls the Exercises "the basic design for Jesuit spirituality and ministry."

From its earliest years, the Society both conducted foreign missionsIgnatius's companion Francis Xavier (1506-52) traveled to India and other parts of Southeast Asia-and founded and ran schools for young laymen. The Society's carefully elaborated structure and ethos, its investment in schools, and its missionary energy together spurred the growth of the order. Theologian Avery Dulles (1918-2008) describes the Jesuits as animated by a "mysticism of involvement." By Ignatius's death in 1556, the Society had about one thousand members and labored throughout much of Western Europe, as well as India and Brazil.

1 John W. O'Malley, S.J., "Some Distinctive Characteristics of Jesuit Spirituality in the Sixteenth Century," in Jesuit Spirituality: A Now and Future Resource, ed. John W. O’Malley, S.J., Vincent T. O’Keefe, S.J., and John W. Padberg, S.J. (Chicago: Loyola University Press, 1990), 1-20, here 2.

2 Quoted in Tricia Pyne, "The Maryland Catholic Community, 16o9-1775: A Study in Culture, Region, and Church" (PhD diss., Catholic University of America, 1996), 8. 
The Society's schools and missions emerged from Jesuits' conviction that humanistic knowledge and Catholicism must be assertively spread and that the Jesuits were the people to do it. The two endeavors nurtured each other: Jesuit schools inspired some students to become Jesuits themselves, and the hardships of the missions offered a new golden legend for those studying and teaching in the schools. ${ }^{3}$ Both enterprises, moreover, promoted Catholic teaching against a backdrop of competing religions, whether that meant the Protestantism spreading throughout Europe or the religions of Asia and the New World.

When European conquest of the Americas began in the late fifteenth century, Jesuits-like members of orders such as the Franciscans and the Dominicans - saw the New World as a providential theater for the expansion of God's kingdom. Jesuits evangelized in New France and in the Pays d'en Haut. ${ }^{4}$ They labored in New Spain, including in the desert regions of what is now the American Southwest. Jesuits were among the earliest settlers in the English colony of Maryland. In each region, their message partook of shared Jesuit purposes and forms while also reflecting the distinctive contributions of the indigenous peoples among whom they worked and of the empires within which they toiled.

\section{$3 \quad$ New France Takes Root}

The Society of Jesus had close ties to France from its inception: a few of Ignatius's first companions were French and he conceived of the fellowship at the University of Paris. By 1575, France boasted fifteen Jesuit colleges, and the Society cultivated French prelates and aristocrats as patrons. Yet, the French Wars of Religion (1562-98) left Parisian officials and Henry III (1551-89, r.157489) mistrustful; when a former student at one of the Jesuit colleges tried to assassinate Henry IV (1553-1610, r.1589-1610), the order found itself banned in Paris, Normandy, and Burgundy. What followed was, like just about everything else in this early modern world, complicated. Eager to prove the sincerity of his conversion to Catholicism and eager to assert control over the church (or any part of it), Henry IV allowed the Jesuits to return on the condition that all

3 Luke Clossey, Salvation and Globalization in the Early Jesuit Missions (New York: Cambridge University Press, 2008).

4 The Pays d'en Haut, originally an expression used by fur-traders to describe the region in which they traveled, included much of northwest Quebec and Ontario, as well as the Great Lakes Basin upriver from the St. Lawrence. 
members "working in France be French citizens and that every Jesuit take an oath of loyalty to the monarchy upon entry into a French foundation." The edict meant that the Jesuits who sailed to New France were a distinctively French group and one with reason to feel—or at least to demonstrate-loyalty to the crown. Continued political turmoil only bound the Jesuits closer to the French state: when Henry IV was assassinated in 1610, Jesuits in France declared their support of the distinctive "liberty of the Gallican church," which afforded officials of the French state significant influence over matters including ecclesiastical appointments. The Society's superior general worried that the French Jesuits' declaration displeased the pope, but it helped to ensure the order's good standing with the new monarch and the parlements. ${ }^{6}$

The difficulty of navigating French politics met its match in the perils of surviving the New World. Two years after Quebec was founded as the capital of New France in 16o9, the Jesuits Pierre Biard (1567-1622) and Énemond Massé (c.1574-1646) established a fragile mission in Acadia, the region encompassing what is now Nova Scotia, New Brunswick, and northern Maine. The mission proved short-lived. An Englishman, Captain Samuel Argall (1580-1626), sailed from Virginia to destroy Quebec in the name of English interests and the Protestant faith. The years 1625 through 1629 saw a second, fleeting mission established, but it too was crushed by an English expedition; in the year of its destruction, England gained dominion over all of New France. Three years later, the English returned the territory to the French. Samuel de Champlain (15671635), recently released from an English prison, began to build a new settlement at Quebec, and the Jesuit missions to New France began in earnest. Two weeks after the Treaty of Saint-Germain-en-Laye (1514) was signed, Cardinal Richelieu $\left(15^{8} 5^{-1642}\right)$ secured passage for three Jesuits to sail to New France. Récollets came, too, but Jesuits were the dominant order, not least because they had successfully presented themselves as more likely than the Récollets to act in accord with the directions of the French church and monarchy. ${ }^{7}$

In 1632, Paul Le Jeune (1591-1664) arrived in New France to serve as the superior of the Jesuit mission. Le Jeune was a convert from Calvinism who had served in Jesuit colleges around Paris before being chosen to head the Quebec endeavor; his companions were an experienced missionary priest named Anne de Nouë (1587-1646) and a Jesuit lay brother, Gilbert Burel (1585-1661).

5 Eric Nelson, The Jesuits and the Monarchy: Catholic Reform and Political Authority in France (1590-1615) (New York: Routledge, 2005), 78.

6 Bronwen McShea, Apostles of Empire: The Jesuits and New France (Lincoln, NE: University of Nebraska Press, 2019), 6.

7 McShea, Apostles of Empire, 17. 
Under Le Jeune's direction, Jesuits ministered to French settlers in Quebec but devoted much of their efforts to proselytizing indigenous peoples. Le Jeune's extended descriptions of natives' customs and culture, along with his explanations of the Jesuits' purposes and methods, became the first of the Jesuit Relations, annual publications intended, as one Jesuit author put it, "to satisfy the curiosity of those who take pleasure in learning what occurs in foreign nations, and at the same time [offer] material to edify the piety and animate the zeal of apostolic men." ${ }^{8}$ The Relations were also meant to gather support for the Jesuit efforts in New France; their publisher, Sébastien Cramoisy (c.1584-1669), had published Jesuit mission accounts from Asia and Africa, and he supported Cardinal Richelieu's vision of an expanding and proselytizing France. ${ }^{9}$

The Society of Jesus was thrusting itself into an already multicultural world. Indigenous peoples in the region known as New France belonged, in the accounting of modern ethnohistorians, to two large groups, the Algonquians and the Iroquoians. The former tended to live in small, mobile groups and to draw sustenance from hunting, fishing, and foraging, although some members of the Algonquian language group lived in semi-autonomous villages stretching from what is now the Canadian Maritimes to Maine. Iroquois speakers, for their part, tended to cultivate crops and live in larger and more settled communities. Tribes' relationships with each other, with imperial officials, and with Jesuits changed and changed again across the century, and the way the French referred to tribes (for example, designating one group within the Algonquian classification the Algonquins, and one group within the Iroquoian classification the Iroquois) adds to the complexity. What does emerge clearly is a landscape of competing religious and ethnic claims, shifting allegiances and hostilities, and both community building and community destruction. In short, New France was a fitting companion to the early modern European world to which it was yoked.

During this era, Jesuits' labors in the New World formed a small part of their global endeavors. Everywhere they went, members of the Society looked for congruencies between indigenous beliefs and Catholic teachings. Their willingness to see some native practices persist-Jesuits in China, for example, did not seek to disrupt converts' participation in rites honoring Confucius $\left(55^{2-}\right.$ 479 BCE) - elicited criticism from other orders. But Jesuits in both Asia and New France worked among self-governing peoples possessed of cultural and

8 Quoted in Allan Greer, "Introduction," in The Jesuit Relations: Natives and Missionaries in Seventeenth-Century North America, ed. Allan Greer (Boston: Bedford/St. Martin's, 2000), 1-19, here 15 .

9 McShea, Apostles of Empire, 21-23. 
spiritual riches and military and political power; they understood that they could not simply impose their will.

Throughout France's colonial possessions, Jesuits admired elements of native manners and lifestyle - the civility of the Hurons for example, and the physical prowess of many tribes - and hoped that indigenous concepts such as Manitou revealed a monotheism that could be reshaped into Christianity. They saw some reasons for optimism. Jesuits' acquisition of native languages, diligence in translating Christian materials, and immersion in-or at least proximity to-native culture left them more successful than English missionaries in making known their form of Christianity. ${ }^{10}$ Jesuit ability to predict astronomical events and their confident assertion of spiritual authority (occasionally and coincidentally accompanied by the recovery of sick people in their presence) impressed some indigenous people as a "personal shamanistic power."11 Jesuits in North America also sought-as they did elsewhere in the world - to convert elites; the Jesuit Francois-Joseph Le Mercier (1604-90) was encouraged by the decision of a Huron chief, Tsiouendaentaha (dates unknown), to be baptized in 1637 .

Yet, the story of Jesuit interactions with natives in North America is filled with misunderstanding, conflict, resistance, and tragedy. Jesuits found that in North America as in Asia, it was no easy matter to convince people to give up one faith to adopt another. Ethnohistorian James P. Ronda explains that "when Jesuits pressed the Hurons and Montagnais to give up their ways, they consistently received the same answers: 'such is the custom of our country,' or 'such is not our custom; your world is different from ours; the God who created yours did not create ours."'12

The French, moreover, brought with them far more than religion: they carried diseases, plants, and livestock that shockingly transformed the Indians' world. As epidemics devastated tribes throughout the 163os, French Jesuits observed that Indians blamed them. Lacking a germ theory and confident in their mission, Jesuits dismissed the Indians' belief as superstition. Moreover, because they were unable to persuade most healthy adults to adopt Catholicism, and because they believed that baptism saved souls, Jesuits focused their attention on people they thought might not be long for this world: the very young, the

10 James Axtell, Invasion Within: The Contest of Cultures in Colonial North America (New York: Oxford University Press, 1986), 43.

11 Daniel Richter, The Ordeal of the Longhouse: The Peoples of the Iroquois League in the Era of European Colonization (Chapel Hill, NC: University of North Carolina Press, 1992), 113.

12 James P. Ronda, "We are well as we are': An Indian Critique of Seventeenth-Century Christian Missions," William and Mary Quarterly 34, no. 1 (1977): 66-82, here 81; Ronda is quoting the Jesuit Relations, 10:19, 11:7-9. 
very old, and the very sick. When many of the newly baptized did in fact die, indigenous people recoiled.

Trying to persuade adults to seek baptism for themselves and their children, Jesuits used a mixture of fear and hope. God loved and protected the baptized, missionaries explained, and God cast the unbaptized into eternal punishment. Some Jesuits began to set stricter conditions for baptizing the very young or very sick, but this effort to preserve the full meaning of the sacrament became the source of new conflict. Jesuits insisted that taking baptized Indian children away from their families in order to educate them at boarding schools, such as the newly established seminary at Notre-Dame-des Anges, benefited the children's souls. Indian families resisted the practice, and Jesuits abandoned the schools by the 1640s, instead establishing Sunday schools at missionary residences in Huronia and a seasonal "seminary" for young Huron traders..$^{13}$

Were Jesuits in New France agents of empire? Historians have at times made sharp distinctions between Jesuit and Anglo-Protestant missionary efforts, portraying the former as less bound up with imperial aims than the latter. The dividing line is in reality not quite so bright. Le Jeune believed that the creation of a successful town, Quebec, and the development of profitable agriculture in the region, would simultaneously improve the material well-being of indigenous peoples and make them more likely to accept Christianity; he also argued that a flourishing colony would strengthen France, providing it with a new and loyal population as well as grain, ore, and timber. As Jesuits saw it, moreover, France itself was also a realm in need of reform. Historian Bronwen McShea argues that Jesuit efforts in North America accorded with those of their brethren within France who worked to disabuse peasants of beliefs the Jesuits considered superstitious and primitive. Even the Jesuits' terms for native shamanssorcerers, jugglers, and charlatans - mirror those that educated elites within France had begun to direct against French folk healers. Both Europe and the New World were mission fields. ${ }^{14}$

Throughout the 163os, Jesuit missionary efforts persisted in New France; the missionary Le Mercier estimated that the indigenous community included "more than a thousand Christians." 15 In 1637, the Society founded the town of Sillery near Quebec, hopeful of finding new converts and of serving those who had already adopted the faith. Some Indians found meaning and solace in Christianity, and some saw value in diplomatic and political alliance with

13 Takao Abé, The Jesuit Mission to New France: A New Interpretation in the Light of the Earlier Jesuit Experience in Japan (Leiden: Brill, 2011), 109-11, 120.

14 McShea, Apostles of Empire, 88-89, 6o-63.

15 Quoted in Richter, Ordeal of the Longhouse, 3. 
Europeans. Yet, the Relations observed that even those who came to Sillery used it as they saw fit. Rather than living permanently as villagers, Indians departed for long hunting trips, only returning to Sillery for rest. The town offered no protection from the era's horrific epidemics: Sillery's hospital treated about one hundred native patients in the year 1642-43, out of a native population of around three hundred. ${ }^{16}$

Cultural fracturing was as evident as disease. Historian Dan Richter has argued that Jesuit success in proselytizing a group of natives "usually also inspired the formation of an opposition group."17 Despite Jesuits' willingness to tolerate the persistence of some indigenous practices, priests encouragedand, when they could, required - converts to cease participating in many native feasts and rituals, thus ensuring deepening divisions between converts and those who maintained traditional practices. Proselytizing and factions went together.

During the 1640s, the profound disruptions of the era begat full-scale war, as Iroquoians increased attacks on the Hurons, Montagnais, and Algonquins, as well as on the French themselves. Allied primarily with the British and Dutch, and armed mainly through trade with the latter, Iroquoians sought to take over the resources of Alonquian tribes. The conflict became known as the Beaver Wars (c.1642-98), but historians now believe that the need to replace individuals lost to war and disease fueled the Iroquois' war-making as much as the desire to gain more hunting ground for beaver. Whatever their mix of motives, Iroquois raiders killed many and took captive others. Women and children might be adopted into the tribe to replace those lost to disease and war, but men were often tortured to death. A second conflict, known as Kieft's War (1643-45), raged on Long Island and Connecticut, causing still more native deaths. By 1649, Hurons had fled the lower St. Lawrence region and the Huron Confederacy was shattered. Some stunned survivors turned to French protection and religion, and entire Huron villages converted.

Although in far smaller numbers than the native population, Jesuits suffered and died during these conflicts, too; the years of war introduced new heroes of the Relations, the North American martyrs. Isaac Jogues (1607-46) was the first. A Jesuit who had been traveling with Hurons and two other Frenchmen when he was taken prisoner by Mohawks, Jogues suffered horrifying tortures before being rescued by Dutch traders. Sent to France to recover, Jogues was hailed as a "living martyr" but insisted on returning to New France, where he was again

16 Abé, Jesuit Mission to New France, $15^{2}$.

17 Daniel Richter, "Iroquois versus Iroquois: Jesuit Missions and Christianity in Village Politics, 1642-1686," Ethnohistory 32, no. 1 (1985): 1-16, here 1. 
captured, and this time killed. Seven other French Jesuits lost their lives during the era. Missionaries remained committed to drawing natives into Christianity and a French way of life, and even participated in efforts to draw the fighting to a successful close: a Jesuit priest, Gabriel Druillettes (1610-81), was sent to New England, where he offered French trade in exchange for English help defeating the Mohawks. Yet, the Relations of this era celebrated not patriotic endeavor, let alone diplomatic or military cunning, but rather the selfless, suffering spirituality of the North American martyrs. ${ }^{18}$

The priests' brethren were not the only ones to contemplate their sacrifices. Among some Iroquoian peoples, Jogues's courage heightened respect for the Jesuits. After the Iroquois Wars concluded, Jesuits received permission to work in Iroquois villages. Some Iroquois feared and loathed the priests, not least because they had heard from other natives that the Jesuits were secretive, judgmental, and worst, carriers of death. Yet, the Iroquois also contained small groups of Christian captives who had maintained their faith and spoke warmly of the Jesuits; given that the Five Nations population had shrunk during the wars, some hoped the Jesuits brought with them spiritual or temporal power. The Mohawk headman Garakontie (d.1676) converted to Catholicism in 1670 and remained a Christian and advocate of allegiance with the French until his death six years later; many of his kin followed Garakontie in conversion.

\section{4}

\section{Royal Rule}

In 1663, Louis XIV (1638-1715, r.1643-1715) imposed direct royal rule over New France; in 1665, a regiment of 1,200 men arrived, and so did a royal intendant. Some historians have argued that the change marked a defeat for Jesuit missionaries because it replaced Jesuit initiative with royal decree, imposing a policy of Frenchification that did not accord with Jesuits' willingness to integrate Catholicism into native practice. Yet, Jesuits such as Le Jeune had long sought to transform Indians' way of life as well as their spirituality, and Jesuits themselves had called for greater French military presence. The royal intendant, moreover, turned out to have been educated by the Jesuits; his promotion of French emigration to New France and his encouragement of western exploration pleased the Society.

Often, Jesuits saw challenges emerging not from conflicts with the state but rather from tensions with other orders and within the Society itself.

18 Emma Anderson, The Death and Afterlife of the North American Martyrs (Cambridge, MA: Harvard University Press, 2013). 
Members of the Society disagreed over a plan to create a procurator general for all missions emerging from the province of Paris, which included activities in Vietnam, the Ottoman Empire, and the Antilles; some worried that the Canadian missions would suffer from neglect. There were also skirmishes with the Society of Saint-Sulpice, whose priests had begun arriving in New France in the late 165os. Although Jesuits at first welcomed the Sulpicians' work among French settlers in Montreal—work the Jesuit missionaries had little interest in undertaking - disputes over ecclesiastical jurisdiction eventually led to harsh words. The resolution of that dispute - a secular priest named François-Xavier de Montmorency-Laval (1623-1708) was appointed bishop over all new France-only led to more conflict among the Jesuits themselves, as those working in New France resolved to cooperate with the Sulpicians, while Jesuits in Paris, pursuing their vision of a global Jesuit ministry, mistrusted such cooperation. ${ }^{19}$ Even the Relations fell victim to struggles over authority and were abandoned in 1673 .

Louis XIV's reign saw new towns founded and the plans of Montreal and Quebec straightened, at least somewhat, into grids. The Jesuit college in Quebec City, which had been founded in 1635 with monies donated in response to Le Jeune's appeals, began receiving students from a new seminary. Jesuits also created mission settlements loosely modeled on the famous reducciones of Paraguay, but less removed from European settlements than the Latin American originals. (In some ways, the New France communities more closely resembled the Christian settlements Jesuit missionaries created within Japan than they did Latin American reductions. ${ }^{20}$ ) The settlements included Kahnawake, established near Montreal but named for an area in New York that had been home to Mohawks; Notre Dame de Lorette, near Quebec; and a Sulpician establishment on Montreal Island. Natives from the area along the Kennebec River, whose waters divided New England from New France, migrated to Kahnawake during the calamity of King Philip's War (1675-76), a thwarted uprising among New England native peoples that resulted in thousands of deaths. Refuge proved hard to find.

Women and adoptees were prominent among the Iroquois who chose to move to the villages, and priests at Kahnawake organized female sodalities, encouraging young women to commit themselves to virginity. One young woman who participated, Catherine Tekakwitha (1656-8o), had lost her family and been scarred herself in a smallpox epidemic. She twice refused marriage and participated passionately—if, to our centuries-removed eyes, somewhat

\footnotetext{
19 McShea, Apostles of Empire, 178.

20 Abe, Jesuit Mission to New France.
} 
unknowably - in Catholic penance and worship. Catherine died at Kahnawake at the age of twenty-four, after impressing her Jesuit confessor, Pierre Cholenec (1641-1723), as fervently pious. Cholenec's account of Catherine's life began a veneration that culminated centuries later in her canonization as a saint. Perhaps due to the painfully complex history of colonization and missionary work in New France, Catherine Tekakwitha has been venerated more among native peoples of the American Southwest - who lived and suffered under a different imperial regime - than those of her own region. ${ }^{21}$

In the end, the migration of dedicated native Christians to settlement towns combined with improving relations between the Iroquois and the British to weaken and then doom Jesuit missionizing to the Iroquois. In 1682, a Jesuit named Étienne de Carheil (1633-1726) was driven from New York; six years earlier, Claude Dablon (1618-97) had already complained that natives "talk[ed] only of breaking the missionaries' heads, by way of beginning hostilities." 22 Missionaries feared for their lives, and by 1684, most had abandoned their posts in Iroquoia. The Jesuit missions among the Five Nations came to an end.

As always, events in the New World were entwined with those of the Old. In 1688, England underwent its Glorious Revolution and a Catholic Stuart lost his throne. England's newly crowned Protestant monarchs, William of Orange (1650-1702, r.1689-1702) and Mary II of England (1662-94, r.1689-94), joined the League of Augsburg in war with France (to which the deposed James [1633-1701, r.1685-88] had fled). So, began twenty-five years of nearly constant warfare in Europe and North America. King William's War (1689-98 and Queen Anne's War (1702-13) heightened New Englanders' fears of the French and their native allies and heightened English Protestants' distaste for the Catholic faith they associated with their enemies. English settlers in North America outnumbered the French by twelve to one, but they were dispersed over broad distances and organized into highly distinct colonies; the French also boasted more effective alliances with native peoples. When the English lost Fort Loyal, in what is now Portland, Maine, to the French in 169o, frightened settlers fled Casco Bay, leaving poorly defended settlements in what is now Maine and New Hampshire to be raided by Abenaki. Massachusetts encouraged resettlement of the area and built Casco Fort to defend it, but in 1704, the town of Deerfield, Massachusetts, lost over one hundred people to a raid; captives were brought to Montreal and Kahnawake. English settlers and officials suspected Jesuits of conspiring with Indian allies, and rumors spread that Abenaki living in a mission village called Norridgewock, not far from Boston, had their scalping

\footnotetext{
21 Allan Greer, Mohawk Saint: Catherine Tekakwitha and the Jesuits (New York: Oxford University Press, 2006), 205.

22 Richter, Ordeal of the Longhouse, 142.
} 
knives and tomahawks blessed before raids.. ${ }^{23}$ The English, for their part, attacked French and Indian settlements near Penobscot Bay and destroyed the trading post of Taconic.

The settlement of Norridgewock lay in the midst of these ethnic, imperial, and religious competitions. And in the midst of Norridgewock lived a Jesuit, known variously as Sébastien Racle or Rale (1657-1724), who had lived with the Abenaki for decades. Racle learned their language, translating Xavier's litany into Abenaki, and growing in respect for Abenaki culture even as he continued to try to convert the Abenaki to Christianity. Racle inspired English animosity on economic and political as well as on spiritual grounds. French settlers who had established a fishing company off the coast of Maine feared Racle and other Jesuits were too successful in encouraging Indians to move to Norridgewock and mission towns such as Sillery; they believed that the migration endangered profitable French trade with coastal Indians. In reality, the migration of the natives accorded with imperial policy because it gathered Indians nearer Quebec. Nonetheless, the fishermen's protests succeeded in preventing Jesuits from establishing a coastal mission. Racle and the Abenaki abandoned Norridgewock as Queen Anne's War dragged on. ${ }^{24}$

\section{5}

\section{The Pays d'en Haut and Louisiana}

While Jesuits labored in the east, they had also begun to expand the French presence into the Great Lakes region. Jesuits established a mission at Sault-Ste. Marie in 1668 and the next year founded St. Francis Xavier in Green Bay. After helping to plant the missions in present-day Michigan, Jacques Marquette (1637-75) joined Louis Jolliet (1645-170o) and five others in a search for the direction and mouth of the Mississippi River. The party traveled in canoes, guided by Miami Indians and warned by Menominees of dangers that lay south. Marquette's account of the peoples, landscapes, and animals of the lands along the Wisconsin, Illinois, and Mississippi rivers became part of the Jesuit Relations. Marquette described the party's arrival at a Peoria Village near the Des Moines River, where Illinois peoples prepared a feast and dance, welcoming the explorers while also making clear the Illinois were the hosts-and

\footnotetext{
23 Fred Anderson, Crucible of War: The Seven Years' War and the Fate of Empire in British North America, 1754-1766 (New York: Alfred A. Knopf, 200o); Thomas J. Lappas, "A Victim of His Own Love: Sébastien Racle, Native Americans, and Religious Politics in Eighteenth-Century New France" (PhD diss., Indiana University, 2003), 102. 
therefore controlled the territory. That control was fairly recent: the Illinois descended from Algonquian peoples who had migrated west beginning in the thirteenth century, developing a flexible and powerful society that combined hunting of bison (once the animal arrived in the prairies around 1500) with agriculture. The complex world of the Illinoi, and the enormous Great Lakes basin itself, became known to the French as the Pays d'en Haut.

Even as native peoples in New France faced epidemics and warfare, the Illinois thrived. Continuing to hunt bison, they raided Siouan-speakers in the west as well as tribes to the south, using captives to augment their own population. The first, glancing encounters between Illinois and Jesuits left some missionaries confident that the Illinois worldview was rapidly becoming Catholic, or at least something close to Catholic. Marquette approvingly described Indians who honored a cross with animal skins; another priest, Claude Allouez (1622-89), was pleased to see Illinois burn tobacco at an altar. "We keep a little of their usage," Marquette wrote, "and take from it all that is bad." In reality, the Illinois were not eager converts but rather innovators, "opportunistic" in the word of one recent historian. Although Jesuits believed them to be incipient Christians, they were instead eager to use any ideas and alliances that might enhance their mastery of their environment. ${ }^{25}$

Imperial officials in Quebec were at first unimpressed by Jesuit efforts to gain support for missionary work in the Illinois Valley. That changed in 1680, when six hundred Iroquois warriors invaded the Illinois country, destroying crops, burning villages, and torturing and killing natives. French observers feared that the Iroquois would soon dominate the region, putting at risk the fur trade and any balance of power between French and English-allied natives. As a result, the French decided to support the Illinois.

In the Illinois country more than had been the case in New France, the methods of empire would conflict with the methods of the Jesuits. In contrast to imperial directives to gather native peoples in villages and "Frenchify" them, Jesuits preferred "flying missions" in remote locations; Marquette's Immaculate Conception mission was farther from an urban center than any mission the Jesuits had ever established. Convinced that the Illinois were already developing a sustainable form of Catholicism, Jesuits had no desire either to force them to live like Frenchmen or to expose natives to the intemperance and corruption they believed French settlers would bring. Jesuits temporarily won the day. Imperial officials came to see missionaries in the region as essential to the alliance with what was now the demonstrably powerful Illinois people. But

25 Robert Morrissey, Empire by Collaboration: Indians, Colonists, and Governments in Colonial Illinois Country (Philadelphia: University of Pennsylvania Press, 2015), 36-37. 
Illinois no more wanted to avoid the French entirely than they wanted to become European-style peasants. ${ }^{26}$ Instead, a settlement known as the Grand Village of the Kaskaskia grew and become multiethnic, coming to include Frenchmen, Chickasaw, and Shawnees, as well as the Illinois peoples.

By the 169os, Jesuits had baptized hundreds of Indians in the region yet were increasingly dissatisfied with the state of the missions. Nor had the French in the area submitted themselves readily to either clerical or imperial guidance; a rich fur trader named Michel Accault (d.1702), whom Recollet Louis Hennepin (1626-1704) called "famous in this Illinois country for all his debaucheries," found a sufficiently unregulated society that he paid six thousand livres' worth of beaver to become "landlord" of a significant part of the Illinois country.

Late in the century, a new generation of Jesuit priests arrived among the Illinois. Led by Jacques Gravier (1651-1708), they worked to master the language. Gravier created a dictionary that demonstrates great familiarity with Illinois culture. Gravier recognized that his brethren had overestimated the success of their missionary efforts. But he also saw that some women among the Illinois found in Jesuit teachings an alternative to an unhappy domestic life. The bison economy, organized around men's hunting and women's processing of the animal, laid tremendous burdens on women. To make matters more difficult, many native women had been brought as captives into the Illinois territory and lived in polygamous marriages that functioned more as labor systems than as affective families. Jesuits also reported physical violence within these relationships. Jesuit sources should not be taken uncritically, since Jesuits believed a French Catholic social organization and spirituality was superior to what they found among indigenous peoples in the New World. Yet Jesuits' descriptions of the Illinois' gender practices are distinct from Jesuit accounts of other tribes, and ethnographers and historians agree both that the Great Lake societies were not matrilineal—unlike many native communities in New France - and that the presence of female captives raised the odds of expropriative or abusive relationships. ${ }^{27}$ Jesuit teachings may have offered an appealing theological or ethical vision.

It was, however, a highly placed Illinois woman rather than a captive who provoked a dramatic new phase in Illinois-French relations. Marie Rouensa (c.1677-1725) was the daughter of the chief of the Kaskaskia community; her father arranged a marriage for her with the wealthy fur-trader-and reputed rogue-Accault. Marie had become a Catholic, and she resisted the marriage, whether out of mistrust of Accault or a wish to avoid marriage entirely. Her

26 Morrissey, Empire by Collaboration, 45, 52-60.

27 Morrissey, Empire by Collaboration. 
angry father drove her naked from his home, but Gravier supported her. In the end, she offered a compromise: if Accault agreed to live as a Christian and help her and Gravier nurture Catholicism in the region, she would marry him. Accault agreed. Marie's father, Mamenthouensa (dates unknown), agreed to Gravier's request that he "gather all the chiefs of the village in his cabin, and retract all that he had said, because it was all untrue; to express his regret for having forbidden them to pray to God." ${ }^{28}$ Accault in fact did become a dedicated Catholic, praised by Gravier and other clerics for his work on behalf of the mission.

The influence of Marie Accault and her husband enhanced the ability of Jesuits to evangelize. Such relationships also changed Jesuits' view of marriage between French and indigenous people in the region. The alliances worked differently in the patrilocal and patrilineal society of the Illinois than they did in New France. In the latter, both imperial officials and Jesuits commented that men who married Indian women took on native ways, rather than the women becoming francisées, or Frenchified. Among the Illinois, some native women saw Christianity as an improvement; after marrying, they joined their husbands in new households, rather than the husband joining the woman's family. Marriages between Indian women and French men (many of whom had practiced an attenuated Catholicism at most) seemed to foster Christian observance in both husband and wife. So Jesuits believed they should be promoted. ${ }^{29}$

While Jesuits labored in the west, imperial conflict in the east continued. At last, 1713 brought an end to Queen Anne's War. But the Treaty of Utrecht left the border between New France and New England unclear. English settlers moved into the Kennebec Valley, built trading posts, and offered the Indians Protestant missionaries; the Jesuit Racle and the Abenaki returned to Norridgewock. The Abenaki rejected English missionaries' proselytizing, and as the years passed, hostility grew between Norridgewock-including Racleand the English settlers moving into the region. Racle encouraged the Abenaki to kill English settlers' livestock, perhaps understanding the tactic as necessary to protect natives from English encroachment and liquor sales. Racle also distributed gifts, guns, and ammunition among the Indians and organized conferences among tribes. ${ }^{30}$

His tactics and insistence that the Abenaki would not be driven from Norridgewock made Racle a villain to New Englanders, the kind of secretive,

28 Morrissey, Empire by Collaboration, 8o-82, quote at 81 .

29 Robert Morrissey, "Kaskaskia Social Network: Kinship and Assimilation in the FrenchIllinois Borderlands, 1695-1735," William and Mary Quarterly 70, no. 1 (2013): 103-46.

30 Lappas, "Victim of His Own Love," 183. 
powerful Jesuit who loomed large in the Anglo-American imagination. In the winter of 1722, the General Council of Massachusetts authorized a mission to capture him. Scores of militiamen paddled up the Kennebec to Norridgewock. Failing to find Racle, they satisfied themselves with ransacking his cabin and destroying his food stores; the party also brought back to Boston a strongbox containing letters revealing that the Jesuit had indeed become a useful partner to French civil and military authorities. Two years later, after continued hostilities between the Abenaki and English, two hundred Englishmen, along with a small group of Mohawks, returned to Norridgewock, where they killed and scalped the wife of an Abenaki sachem, or leader. Encountering Racle inside his cabin, a New Englander shot the Jesuit dead. The official statement of the man who did the deed was that Racle was reloading a weapon and preparing to fire. Whatever the truth, Racle was scalped, and his scalp and that of the Abenaki dead were brought back to Boston and displayed. Racle's death marked the end of Jesuit efforts in the area, though Jesuits lived on in New Englanders' imaginations, figures of conspiracy, foreignness, and danger. ${ }^{31}$

French Jesuits continued to labor in the Illinois country, which developed as it had begun: distinctively. In 1717, French officials made Illinois part of the Louisiana colony. Intermarriage of French settlers and natives, which was formally (although not effectively) banned in Louisiana, was at first allowed to continue. In the early 173 os, concerned that native widows would inherit land and perhaps not be inclined to use it in ways amenable to the empire, Louisiana's officials tried to end intermarriage in the Pays d'en Haut. But there were many — and in some cases wealthy — intermarried families in the region, and Frenchmen were already acting informally to limit the ability of Indian widows to make their own decisions about property. The people of the region largely ignored formal imperial directives over marriage and race, even as European settlers created a racial hierarchy with themselves at its apex. The French were also losing influence more generally: the Illinois proved increasingly eager to work with British traders and even directly with British officials.

The Jesuit Pierre-François-Xavier de Charlevoix (1682-1761) penned observations of the peoples, places, and plants of this region during the brief period of French dominance. Charlevoix had first been sent to North America shortly after his ordination, arriving in Quebec in 1705 and spending three years teaching students in the company of other missionaries. Charlevoix returned to France, completed his formation, and wrote an ambitious, three-volume account of Jesuit missionaries in Japan. In 1719, Charlevoix was asked to recommend boundaries for Acadia, still in dispute after the Treaty of Utrecht. The 
next year, he returned to New France and embarked on a journey that first took him westward to the Great Lakes, then southward along the Illinois River to the Mississippi. Charlevoix did not find the hoped for (and imaginary) "western sea," but his account of the voyage-in the form of letters addressed to a French aristocrat and a long essay on native Americans-is an important contribution to Jesuit ethnographies of the French possessions. ${ }^{32}$

Southward from the Pays d'en Haut, Jesuits settled in New Orleans in 1737 and also worked elsewhere in what was known as "lower Louisiana." Five Jesuits were killed between 1729 and 1763 , reportedly by natives hostile to French settlement. This was not only a story of Jesuit suffering, however. The Society actively participated in an increasingly powerful part of the North American economy: plantation slavery. Jesuits held people in bondage in French Louisiana from the early years of their presence. Labor expropriated from enslaved people provided significant resources for the order, implicating it in what contemporary Jesuits of the central and southern province would centuries later consider the original sin of the United States.

The region known as the Pimería Alta was named for tribes who shared a language group known to the Spanish as Pima. Comprising Sonora and Sinaloa, the territory also included southern Arizona. Unlike the other regions of the Spanish Empire in which Jesuits labored, the Pimería Alta would, at least in part, one day lie within the United States. These northern reaches of New Spain - the lands arid, the mines poorer than those of South America, the indigenous population smaller-lay at the ragged edges of Spanish empire and interests. The Jesuits who labored there knew it.

Like Nueva Vizcaya to its south, the Pimería Alta contained mines from which the Spanish extracted ores, using both enslaved Africans and Indians whose labor was forcibly claimed through the system known as repartimiento. Colonization in the region also brought livestock and wheat cultivation. Jesuits shared the territory with Franciscans, all of the missionaries struggling to coax or coerce the region's indigenous people toward Catholic teachings

32 David M. Hayne, "Charlevoix, Pierre-François-Xavier De," in Dictionary of Canadian Biography, vol. 3 (Toronto: University of Toronto/Université Laval, 2003-); http://www .biographi.ca/en/bio/charlevoix_pierre_francois_xavier_de_3E.html (accessed November 7, 2019); Takao Abé, "Introduction: Iberian and French Jesuits from an International Perspective," in Abé, Jesuit Mission to New France, 1-12. 
and European economic and cultural practices. If successfully imposed, those practices would have enriched Spanish coffers by transforming the nomadic and semi-nomadic tribes into sedentary peoples whose labor could be expropriated and whose loyalty commanded.

Missionaries to New Spain unwittingly brought with them diseases that tormented and killed native peoples, as well as livestock that devastated native economies and cultures. As in New France, natives theorized that the priests were in some way responsible for the suffering, while Jesuits dismissed such theories as superstition and rushed to baptize the ill—rendering themselves even more suspect when Indians observed that many of those recently baptized soon died. ("God harvested infants as his first fruits of heaven," one Jesuit wrote. ${ }^{33}$ ) Missionaries also tried to gather survivors of epidemics in ways that made both proselytizing and expropriating labor more efficient, further compounding the trauma. Some combination of curiosity, desperation, interest, and coercion - the relative importance of each unknowable in any individual or group — brought native bands into the settlements Jesuits established. Far smaller than the Paraguayan reducciones, these settlements, like those established in New France, were often multiethnic, reflecting the disorder and improvisation wrought by colonization. Throughout northern New Spain, Jesuits also cooperated with encomienda: encomenderos used Indian labor while fulfilling their obligation to provide religious instruction to natives by helping to coerce Indians to remain within the Jesuit settlements. ${ }^{34}$

Jesuits in Nueva Vizcaya and the Pimería Alta established schools in which to train Indian boys in Catholicism; they also used the rituals and material culture of their European Catholicism - images, incense, gestures, feast days- to attract indigenous peoples and, they hoped, to build bridges between indigenous worldviews and Catholic teaching. Jesuits also provided material assistance. Sedentary agriculture disrupted native ecosystems and economies, and then, as the environment changed, offered one of the few paths to survival. Missionaries did not recognize their role in creating economic dependence, but they understood that their offerings of seeds and cattle were essential to their hope of inspiring conversion. "When the Society begins to evangelize, it has to go with the gospel in one hand, and meat and corn in the other," one wrote. ${ }^{35}$

33 Quoted in Brandon L. Bayne, "A Passionate Pacification: Sacrifice and Suffering in the Jesuit Missions of Northwestern New Spain, 1594-1767" (PhD diss., Harvard Divinity School, 2012), 47.

34 Daniel T. Reff, Disease, Depopulation, and Culture Change in Northwestern New Spain, 1518-1764 (Salt Lake City: University of Utah Press, 1991), 22.

35 Reff, Disease, Depopulation, and Culture Change, 15-25, quote at 20. 
Did Indians convert? Lacking the equivalent of the Jesuit Relations, we have even less knowledge of the ways Indians did and did not adopt Catholic beliefs and practices in the Pimería Alta than we do in New France. What we can glimpse suggests the limited usefulness of the word conversion, with its implication of complete and permanent transformation. As in New France, settlements in the Pimería Alta were used as temporary refuges and regrouping points by Indians who had not chosen to transform themselves permanently into Catholic farmers. Epidemics influenced Indians both to enter and leave mission settlements, and traditional patterns of migration, along with resistance to missionary discipline, raids by other Indian groups, and the hope of better labor conditions elsewhere, all prompted migration as well. One scholar has argued that the entire period of Jesuit presence in the region comprised contests between Europeans and indigenous people over the meaning and use of land, with few battles ever permanently won. ${ }^{36}$

Throughout the era of the Jesuits' Pimería Alta missions, those contests had the potential to turn violent. One who faced the native peoples' anger was the very first Jesuit in the area, Gonzalo de Tapia (1561-94). Tapia sailed from Spain to the Indies when still in his twenties and set about learning indigenous languages in order to proselytize. He founded the Jesuits' earliest missions in New Spain in Durango, Pátzcuaro, and San Luis de la Paz. In 1594, when Tapia was still in his early thirties, he was killed by indigenous people in Sinaloa after demanding that civil authorities whip and tonsure a native cacique for his opposition to Christian teachings. The mission continued despite the native peoples' efforts to drive the Jesuits out; Hernando de Santarén (d.1616) arrived in Sinaloa within a week of Tapia's death and pursued aggressive measures to bring tribes such as the Acaxee into physical spaces controlled by the Spanish.

It is not difficult to understand the roots of this and later rebellions. Imperialism, itself violent, begat violence. There is also less evidence of Jesuits finding congruencies between indigenous beliefs and Catholic ones in northern New Spain than in many other parts of the global missionary field. On the contrary, some missionaries seemed to find most threatening practices that might have been seen as kindred, such as Pimas' preservation of bones. Despite

$3^{6}$ For discussions of the inadequacy of conversion to describe the array of choices and alliances made by native peoples, see, for example, Linford Fisher, The Indian Great Awakening: Religion and the Shaping of Native Cultures in Early America (New York: Oxford University Press, 2012), and the essays in Conversion: Old Worlds and New, ed. Kenneth Mills and Anthony Grafton (Rochester, NY: University of Rochester Press, 2003). Cynthia Radding, Wandering Peoples: Colonialism, Ethnic Spaces, and Ecological Frontiers in Northwestern Mexico, 1700-1850 (Durham, NC: Duke University Press, 1997); Bayne, "Passionate Pacification," 95-97. 
Catholics' own veneration of relics, for example, Jesuits such as Santarén insisted that Indians surrender bones and other items they kept for spiritual purposes; missionaries burned the confiscated bones in a dramatic bonfire. Such an action seems to have been intended to dominate rather than persuade, and Jesuits also proved willing to enlist military force in support of their efforts to undermine the authority of native religious leaders. ${ }^{37}$

Jesuits understood the Pimería Alta to be a hardship posting, one that, through its stark dangers and chronic miseries, fulfilled the heroic mission to which the Society was called. Daily sacrifices were the white martyrdom, understood as a gift to and from God. Indigenous rebellions produced "red martyrdoms," Tapia's death being the first. ${ }^{38}$ In his 1645 History of the Triumphs of Our Holy Faith amongst the Most Barbarous and Fierce Peoples of the New World, the Jesuit provincial Andrés Pérez de Ribas (1576-1655) portrayed the blood and bodies of Christian martyrs - among whose ranks, he suggested, belonged Gonzalo de Tapia—as the water and seed needed for the church to grow. ${ }^{39}$

One hundred years after Tapia's death, the Jesuit missions were still small, struggling, and the objects of native resistance. In 1695, an uprising began during the Easter season. The Jesuit Francisco Javier Saeta (d.1695) had been in the Pimería Alta only a matter of months when he received word on Good Friday that Indians had attacked two of his assistants at a nearby mission. Saeta wrote to a fellow Jesuit asking for help and explaining that he was forwarding relics for safekeeping. "Please don't let me be lost from view," Saeta wrote plaintively. The next day, a group of Indians arrived and killed Saeta along with six indigenous converts. Harsh Spanish reprisals provoked more native violence, until the region was the site of burned missions and fleeing priests and converts. Scores of indigenous people died in the fighting.

The priest to whom Saeta had written his futile letter was a Jesuit named Eusebio Kino (1645-1711). Kino had arrived in the region about seven years before Saeta and was determined that Saeta's death would not threaten the mission's support in Europe. Born in what is now northern Italy (but was then part of the Holy Roman Empire), Kino was educated in Innsbruck, Austria. After joining the Society of Jesus, he lived and worked in Bavaria. Like many other Jesuits, Kino had initially hoped to be sent to Asia, not the New World. But he embraced the hardship of his Pimería Alta posting. During nearly a quarter century of missionary work, Kino founded twenty-four missions and explored the region.

37 Bayne, "Passionate Pacification," 76-82.

38 Bayne, "Passionate Pacification," chapters 4 and 5 (142-91).

39 Bayne, "Passionate Pacification," 17, 26-34. 
In a place already peripheral to Spain's interests, the murder of Saeta and the six indigenous converts might have been seen as evidence that the whole enterprise should be abandoned. Some imperial officials suggested that the northern frontier was impossible to pacify or evangelize and that the Jesuits' missions should be replaced by overt military force and presidios. Kino instead drew on the Jesuit ethos and on the writings of early Christians such as Tertullian (c.155-after $220 \mathrm{CE})$ to argue that Christianity would grow from the sacrifice of martyrs. He wrote an account of Saeta that is, like the Jesuit Relations, both an argument for continued imperial and Society investment, and an accounting of spiritual and earthly labors. Like Ribas's history had done for Tapia, Kino's account placed Saeta's death into a framework of cosmic success rather than earthly failure. Kino, who seems to have kept a relic from Saeta, portrayed the priest as a protomartyr while being careful not to preempt Roman prerogative in deciding who was worthy of veneration. But there was a problem. Martyrdom required that those who killed the martyr did so through "hatred of the faith." Kino did not want to portray the Pima as uniformly hostile to Christianity after a century of missionary efforts. So, he drew attention to the misconduct of imperial officials and soldiers as a source of the Indians' rebellion, lamenting the killing of forty-eight Pima by Spanish soldiers and native allies after Saeta's murder. Kino also suggested that the Jesuits' practice of bringing converts from southern missions north to manage labor and lead worship among the Pima had proved disastrous given hostilities among the tribes. ${ }^{40}$

Whether due to Kino's efforts or institutional inertia, the Jesuit missions in the Pimería Alta continued, and Kino continued to act as both missionary and explorer. Brethren complained that his travels left him an ineffective, or at best often absent, spiritual guide. But Kino understood his two labors to be linked: the geographic knowledge he gained (famously producing a 1701 map in which California was portrayed as a peninsula rather than an island) seemed to him essential for future missionaries as well as for the empire's ability to defend against Apaches and other threats. Kino also directly incorporated his missionary beliefs into his exploration and map-making, giving settlements the names of saints to accompany, or perhaps to overlay, their native names. He drew M's to mark places in which Spanish priests had been martyred. "Not on account of

40 Herbert E. Bolton, Rim of Christendom: A Biography of Eusebio Francisco Kino, Pacific Coast Pioneer (Tucson: University of Arizona Press, 1984), 331-33; Bayne, "Passionate Pacification," 127-36. 
all these or even more murders would the apostolic missionaries of the Society of Jesus abandon their flocks," he wrote of the Jesuit dead. ${ }^{41}$

When Kino died in 1711, he had established twenty-four missions, many with agricultural and livestock-raising economies that involved natives in their sustenance; he also left a cartographic legacy that is celebrated to this day. Interestingly, even as there has been increased attention to the horrific costs of colonization in the American Southwest and parts of northern Mexico, Father Kino's legacy as an evangelist is widely honored.

None of Kino's successors matched his energy or confident vision of what the Pimería Alta region might become. Yet Jesuits continued to labor. German-speaking Jesuits had for years asked to labor in the New World but had been barred from the French and Spanish empires. Once a change in the agreement between the Spanish monarchy and the Society meant that there was no limit to the number of non-Spanish Jesuits who could labor in the empire, many of those in northern New Spain came from provinces of the Germanies, including a number from Bohemia. One such Jesuit felt pride that a church he had built was a better refuge in times of Apache raids than Spanish-built churches. But other German-speakers wrote of the double difficulties of life among unsympathetic Spanish brethren in a land one called a "destitute peninsula." ${ }^{42}$

Jesuits in this latter period of colonization seem not to have achieved any deeper understanding of or respect for the people among whom they labored than had those who came before. In 1743, a missionary wrote in brutal terms of indigenous peoples in the region, deeming them "below animals rather than [...] equal to other humans" and "without any religion, laws, government knowledge of divinity houses or villages." The priest's insistence in the same letter that he hoped to become "a capable instrument in promoting the glory of God to them" suggests the ongoing tragedy of Jesuit—indigenous encounters in the region. ${ }^{43}$

In 1751, indigenous peoples again rose up against the combined forces of empire and Christianity. Seri Indians revolted in Sonora, where Luis Oacpicagigua (Luis of Sáric [d.1755]) organized fifteen thousand people into a coordinated force. As the uprising spread, there were attacks on a mission and on Spanish settlements, and close to one hundred settlers were killed. Pima Indians

\footnotetext{
41 Eusebio Francisco Kino, Kino's Biography of Francisco Javier Saeta, S.J. (St. Louis, MO: St. Louis University, 1971), 127.

42 Bayne, "Passionate Pacification," 157-58; John Francis Bannon, "The Mission Frontier in Sonora, 1620-1687," in Jesuit Missions of Northern Mexico, ed. Charles W. Polzer et al. (New York: Taylor \& Francis, 1991), 35-202, here 122.

43 Bayne, "Passionate Pacification," 16o-62, quotes at 162.
} 
blamed the Jesuits for the rebellion, an excellent strategy given simmering mistrust between imperial officials and the Society. Jesuit missions in the Pimería Alta were by the 176 os as fragile as they were at first planting.

\section{$7 \quad$ Jesuits in the British North American Colonies}

Although English-speaking Jesuits would one day dominate the story of Jesuits in the United States, they form only a small part of the story of the Jesuits in colonial North America. It was a small and hard-won part: Jesuits working in the French and Spanish empires faced endless challenges but at least shared with imperial officials the goal of spreading the Catholic faith. Not so, of course, in the English and (after 1713) British endeavors.

English resentment of foreign-inflected Catholicism was older than the Reformation, dating back at least to the Hundred Years' War (1337-1453) and the Avignon Papacy (1309-77), which had led English benefices to be assigned to absentee, revenue-seeking French clerics. Since Henry viII's (1491-1547, r.1509-47) founding of the Anglican Church, loathing of Catholicism - known commonly as anti-popery-had been a mainstay of Englishness. Just as suspicion of Rome predated Henry's break with the church, so did Englishmen's ties to the Catholic Church persist long after it. English monarchs after Mary $(1516-58$, r.1553-58) were confronted not only with hostile Catholic conspirators willing to die at the stake but also with Catholic gentry demonstrating loyalty to the crown but continuing to hear Mass in their homes. ${ }^{44}$ Oaths required of Catholic subjects always restricted Catholics' ability to profess allegiance both to their country and to their faith, but enforcement of that and other requirements varied across the centuries, and would do so in the colonies as it did in England.

Jesuits provided English Catholics with intellectual leaders and clandestine pastors. The story began in 1580, when the Jesuits Edmund Campion (1540-81) and Robert Persons (1546-1610), determined to reanimate an English Catholicism they found increasingly hollow, entered the country clandestinely. While on the run from Elizabeth I's (1533-16o3, r.1558-1603) bailiffs, Campion published two tracts attacking Anglicanism while denying any interest in overthrowing the queen. The distinction did not impress Elizabeth, and once captured Campion was tortured and killed. Persons fled the country and established a school for the training of English Jesuits in France, called

44 John Bossy, The English Catholic Community, 1570-1850 (New York: Oxford University Press, 1976), 4. 
St. Omer's - the school at which the United States' first bishop, John Carroll, would one day receive his education.

During the seventeenth and eighteenth centuries, English Jesuits lived and worked in France, Italy, the Spanish Netherlands, and Rome itself. Within England, Jesuits worked quietly as chaplains in aristocratic Catholic homes or as clandestine circuit riders, hearing confessions and saying Masses while traveling the countryside under assumed names and sheltering in "priests' holes." ${ }^{25}$ The Jesuits in exile, however, were bolder, with some advocating a reCatholicization of England. Jesuits both at home and abroad were accused of involvement in the Gunpowder Plot and the popish plot, and the brief ascension to influence of the Jesuit Sir Edward Petre (1631-99), during the reign of James II (1633-1701, r.1685-88), only fanned concerns that the Society wielded a treasonous power. Throughout the British Atlantic, Jesuits in fact represented what the English most feared from the Catholic Church and from the postReformation world of religious competition. Jesuits' discipline and commitment to obedience cast them as rigid defenders of Catholic power and global ambition. But Jesuits were also seen as disturbingly subtle and persuasive, God's own conmen.

Jesuits' outsized presence in the Anglo-American imagination was not, as it turns out, confined to Protestants. Catholics in England who were content to live within the confines of the Elizabethan settlement heatedly condemned Jesuits for advocating the overthrow of the Anglican monarchy. In anti-Jesuit tracts, these English Catholics sought to prove their loyalty to the crown by offering up the Jesuit order as the real "papists" - the only Catholics loyal to the pope at the expense of all else. Thus, the Society was often presented as the "bad" Catholics against whom loyal English Catholics defined themselves as they sought a place within the polity. ${ }^{46}$

By the early seventeenth century, the Catholic community in England was concentrated in particular areas of seven northern counties. Most Catholics were farmers, tradespeople, and laborers, but a small group of Catholic gentry was enormously important to the persistence of the religion. On their estates, this lay elite protected and often provisioned clergy, including Jesuits, while

45 Bossy, English Catholic Community, 251-52; Johann P. Sommerville, "Papalist Political Thought and the Controversy over the Jacobean Oath of Allegiance," in Catholics and the "Protestant Nation": Religious Politics and Identity in Early Modern England, ed. Ethan Shagan (Manchester: Manchester University Press, 2005), 162-84; Victor Houliston, Catholic Resistance in Elizabethan England: Robert Persons's Jesuit Polemic, 1580-1610 (Aldershot: Ashgate, 2007).

46 Thomas M. McCoog, S.J., "Construing Martyrdom in the English Catholic Community, 1582-1602," in Shagan, Catholics in the Protestant Nation, 95-127. 
also providing the discrete spaces in which priests offered Mass and the sacraments. Some of those Catholic gentry also sent sons abroad to study St. Omer's. The number of Jesuits in the country grew despite constraints on Catholic worship, and in 1623, when a Jesuit province was established in England, there were over one hundred members of the Society on the island. ${ }^{47}$

While they labored to keep Catholicism alive at home, English Jesuits also grew interested in evangelizing the New World, as their continental brethren were doing. In 1605, Persons was sufficiently moved by the thought of evangelizing indigenous communities to offer to look for help in Rome, should the plan appear to have backing in England or Spain. The crucial support in fact came from a different source: George Calvert, the First Lord Baltimore (c.158o-1632). Calvert had been raised Catholic, adopted Anglicanism as an adolescent, then reclaimed his original faith in his forties. After investing in both the Virginia Company and the East India Company, he obtained a royal charter for a Newfoundland province he called Avalon. Calvert wanted coreligionists and priests to be part of the colony, and he traveled to Newfoundland himself in 1627. He found there a poorly run settlement in an inhospitable country"there is a sad face of wynter upon all this land," he wrote. ${ }^{48}$ A brief stay in Virginia convinced Calvert that it offered a more promising site for his plans, and despite opposition from others and the shipwreck death of his wife and servants, he persisted in this new venture.

As he contemplated his proposed colony, Calvert began a correspondence with a Jesuit known as Andrew White (1579-1656). Having cooperated with Jesuits in a successful effort to remove a bishop Rome tried to establish in England, Calvert was willing again to work with the order. English Jesuits were eager to proselytize and may also have seen Maryland as a potential refuge should their relations with England's government—or with its secular Catholic clergy - prove increasingly difficult. Members of the Society helped to publicize and even to fund Baltimore's plans; because of restrictions placed on them in England, Jesuits needed a place to invest excess cash.

Calvert died in 1632, still in his early fifties. Two months later, his son Cecil, the Second Lord Baltimore (1605-75), obtained a charter for land between

\footnotetext{
47 Robert Emmett Curran, Papist Devils: Catholics in British America, 1574-1783 (Washington, DC: Catholic University of America Press, 2014), 7-10.

48 Curran, Papist Devils, 19-27, quote at 26.
} 
Delaware Bay and the Potomac River. Cecil Calvert's plan for Maryland, in accord with his father's, was to create a New World Society modeled on feudal England. Gentry would govern the colony, pay to transport a servant workforce, and, as in the northern counties of England, also provide the setting for a Catholicism that flourished within gentry houses rather than in public spaces. From Maryland's earliest days, wealthy Catholics constituted a small proportion of the colony's settlers but held a great deal of its wealth and influence. ${ }^{49}$

The Second Lord Baltimore valued Jesuits' participation but tried to set their future in Maryland on a somewhat narrow path. Jesuit migrants to the colony were not given the privileges and immunities of clergy. Instead, they traveled as Englishmen, entitled to own property individually (rather than corporately) and expected to use the proceeds from that property to fund their mission. This approach got around the Statutes of Mortmain (1279 and 1290), which prohibited corporations, including religious bodies, from acquiring land. It also reduced the power of the Catholic Church in the colony, a fact that both protected Baltimore against anti-papist sentiment and diminished the potential for Jesuits to become a rival source of authority. Jesuits' landowning and need to support themselves had momentous consequences: it drew them as willing participants into the plantation system. In the absence of state support, Jesuits relied on enslaved labor, along with donations from the faithful (many of whom were also slaveholders) for resources. The first documentary proof of slaveholding among Jesuits dates to 1717 , but it is probable that it began considerably earlier, with Jesuits perhaps reluctant to keep a careful record of possessions for fear of confiscation. By the late colonial period, Maryland's Jesuits would enslave 192 people. It was their largest single investment. ${ }^{50}$

Early Years in Maryland

In 1634, the Ark and the Dove arrived on St. Clement's Island, upstream from the Chesapeake Bay. The ships bore over two hundred colonists, including three Jesuits. The priests celebrated Mass and erected a cross on arrival. Thirty years later, Maryland's Jesuits would build a large brick church on the highest point in St. Mary's City. The colony's Catholic chapels were plain inside and

49 Curran, Papist Devils, 30-31.

50 Thomas Murphy, S.J., Jesuit Slaveholding in Maryland, 1717-1838 (New York: Routledge, 2001), Xv. 
out. Yet from that first day on St. Clement's Island, Jesuits created a more public religion than the Lords Baltimore had intended. ${ }^{51}$

More Jesuits followed those first three, and they brought with them indentured servants, thereby-as Lord Baltimore's Conditions of Plantation set forth-being allotted more land. Jesuits and their indentured servants comprised sixty-two of the roughly three hundred settlers in the first five years of Maryland's history, and Jesuits possessed over sixteen thousand acres. For the next eighty years, Jesuits acquired new parcels under the headright system, as well as through purchase and legacies; they were also given land by Patuxent Indians. ${ }^{52}$

Fertile land made the colony viable, but Maryland developed in a way different than the Lords Baltimore had imagined. The colony quickly came to be organized around one crop: tobacco, and that crop unsettled Calvert's vision of a feudal society. Landowners cleared land for its planting, used it as the colony's currency, and exported it in large quantities - one hundred pounds of it by $1634{ }^{53}$ Tobacco's profitability—although volatile—-helped to undermine the Calverts' vision of a feudal society. Servants survived their indenture and were able to earn enough money in wages to purchase land, tools, and, in the early years, servants. Farms far smaller than those owned by the colony's elites could support themselves and even provide their owners some upward mobility, and by the 1640 s, the manorial system was fading.

The Jesuits' goal—evangelizing native Americans—at first seemed more in reach than the Calverts' dream of a feudal society in the New World. Jesuits in Maryland proselytized native Americans, in accord with the Society's original hopes. White described the area's indigenous people as "being [...] of a very loving and kinde nature." ${ }^{54}$ The tribes may have believed that cooperation with the Jesuits would protect them from English encroachments and perhaps from traditional indigenous rivals, as well. White did help the Yaocomico tribe negotiate reasonably favorable trade treaties with settlers. But bitter disagreements over the Jesuits' landownership and their obligations to the government soured their relationship with the proprietors. Jesuit land ownership, in particular their possession of land given them by the Patuxents, caused a swirl of questions about the Catholic clergy's standing in the colony, the colony's legal regime in relation to England's, and, at least in the proprietor's mind,

$51 \quad$ Pyne, "Maryland Catholic Community," 45.

$5^{2}$ Curran, Papist Devils, 45 .

53 Curran, Papist Devils, 39 .

54 Andrew White, S.J., "A Brief Relation of the Voyage unto Maryland, by Father Andrew White, 1634," in Narratives of Early Maryland, 1633-1684, ed. Clayton Colman Hall (New York: Charles Scribner's Sons, 1910), 29-45, here 41. 
the Jesuits' loyalty to the Calvert family. Although Lord Baltimore pulled back from a tentative decision to ban Jesuit migration to Maryland, Jesuits lost their influence within the government and, as a result, lost value to natives as an ally. ${ }^{55}$ White nonetheless persisted in efforts to proselytize, preparing dictionaries and translating the catechism into a local language. In 1640, the chief of the Piscataway tribe converted to Christianity; later, so did an elite young woman within the Patuxent tribe. As always, however, it is difficult to know what these conversions meant to Native Americans themselves, and White's accounts lack the ethnographic richness of the Relations (texts that are of course themselves deeply colored by the Jesuits' views).

In the $1640 s$, events across the Atlantic roiled the fledgling colony. During the English Civil Wars (1642-51), Puritan colonists from Virginia burned Maryland's capital of St. Mary's City and gained control of the colony. Eight Jesuits were captured, with three of those left to their apparent deaths in territory controlled by hostile indigenous peoples; the others were returned to England. Jesuit properties were burnt, as were properties owned by lay Catholics. White was sent in chains to England. Freed but not allowed to return to Maryland, White died in England in 1656. Jesuits slowly returned, but it was to a colony from which Indians had largely departed due to rivalries with the region's other indigenous peoples and to the disruptions caused by settlement itself. By midcentury, the Jesuits' original plans for the colony, like the Calverts', were fading. They largely withdrew from work among native Americans.

After Lord Baltimore regained control of the colony, he sought to establish it on firmer ground. In an effort to promote the peaceful settlement of a variety of Christians - including both Puritans and Catholics - Baltimore wrote what became Maryland's Toleration Act. "No person or persons [...] professing to believe in Jesus Christ, shall from henceforth be anyways troubled, Molested, or discountenanced for or in respect of his or her religion nor in the free exercise thereof within this Province," reads the act, passed in 1649. (Anyone who did not acknowledge the divinity of Jesus Christ could in theory be put to death.) Repealed in 1654-after yet another brief changing of hands of the colony, this one following the execution of Charles I (160o-49, r.1625-49) - the act was reinstated in 1657. It offered a distinctive and explicit, if limited, form of religious

55 Kathleen Scorza, "False Emissaries: The Jesuits among the Piscataways in Early Colonial Maryland, 1634-1648” (MA thesis, Wellesley College, 2007), 3-4; Antoinette Sutto, "Lord Baltimore, the Society of Jesus, and Caroline Absolutism in Maryland, 1630-1645," Journal of British Studies 48, no. 3 (2009): 631-52. 
tolerance for more than thirty years, and it is an important moment in the broad history of the United States' separation of church and state. ${ }^{56}$

By 166o, following decades of tumult, Maryland still had fewer than three thousand settlers. Some had left for Virginia in search of peace and prosperity. The next thirty years brought dramatic change. Immigration rose sharply, with Maryland thought to offer the possibility of landownership and advancement for people of middling means. By 1688 , the settler population was around twenty-five thousand. Many of the newcomers were Protestants and a growing percentage of them came in families rather than as single men. Catholic gentry now settled on lands along the Chesapeake Bay's Eastern Shore, and Irish Catholics, most of them indentured servants, joined English and Scottish Catholics. Franciscans joined the Jesuits in the colony. As the colony grew, Lord Baltimore created St. Mary's as its official capital and made ambitious plans for public buildings.

The Jesuit mission was also growing and changing. No longer focused on the indigenous peoples who had inspired their labors, Jesuits in the colony were "priest planters," conducting missions to Catholic settlers throughout the colony. Jesuits ran a school in St. Mary's County during the last quarter of the seventeenth century and at their manors maintained small libraries, from which Jesuits and laity could borrow books. They established sodalities and made pastoral visits in ways not unlike the Jesuits' missions within Europe. The second half of the seventeenth century also saw a short-lived Jesuit mission in New Jersey and another in New York, where Catholic settlers enjoyed religious toleration (though Catholics worshipped privately) during the proprietorship of the duke of York. ${ }^{57}$ Historian Tricia Pyne argues that because Maryland's Jesuits were neither competing with other Catholic orders nor rooting out Catholic traditions specific to the place, they implemented some Tridentine reforms more thoroughly than occurred elsewhere. Their emphasis was not on feast days and material culture, but rather on an individual's piety, promoted through examination of conscience, knowledge of church teachings, and good works. ${ }^{58}$

56 Curran, Papist Devils, 147-48.

57 Curran, Papist Devils, 104-9.

$5^{8}$ Tricia T. Pyne, "Ritual and Practice in the Maryland Catholic Community, 1634-1776," U.S. Catholic Historian 26, no. 2 (2008): 17-46. 
That emphasis suited not only an English Catholic sensibility but also the colony's economy. As Maryland grew, more freeholders and indentured servants arrived, shifting the demographics of Catholicism in the colony away from the gentry. Jesuits sought and received permission to lessen the number of fast day and feast day requirements; tobacco workers were in some cases specifically absolved of obligations, a privilege that applied during harvesting months. ${ }^{59}$

In 1688, the Glorious Revolution put William and Mary on the throne. The resulting tangle of alliances and animosities helped to precipitate over two decades of imperial warfare. In Maryland, news of James's removal followed on rumors of a conspiracy involving Maryland's Catholics, French settlers, and native allies. To make matters more tense, a Catholic member of the colony's governing council had recently claimed that his authority emerged from the divine right of kings, then commanded a public Mass be offered-and celebrated by a Jesuit-in honor of the birth of a son to James II. None of this boded well for the proprietary government, and in 1689, Lord Baltimore's government was overthrown. Maryland came under the direct rule of the crown.

Worried Catholics enlisted the Spanish ambassador to the English court to petition the crown to protect them, reporting that chapels were being razed and priests driven from the colonies. The petition may have exaggerated the threat in order to bolster the chances of Spanish pressure on William. ${ }^{60}$ But the colony's Catholics had reason to worry: the Protestant Associators, who had overthrown the proprietor, ordered Catholic settlers to give up their arms and ammunition, barred the doors of the brick chapel at St. Mary's City, and banned Catholics from holding office in the colony.

Despite such measures, the Catholic community seems to have remained influential and capable of worshipping publicly for nearly a decade. Jesuits numbered eleven in 1703 and were in fact expanding their work into the Eastern Shore. William assured the Spanish ambassador that Catholics would be allowed to practice their religion throughout the empire (Spain was an important ally against France) and the great brick chapel was soon reopened. In fact, so unabashed were Jesuits that Protestants complained they were openly proselytizing, an act that constituted treason under British penal laws. Maryland's governor tolerated some public worship, but he resented this boldness. The "idolatrous Religion will still continue as it is, if not increase," he conceded

59 Pyne, "Maryland Catholic Community," 77-79; Ronald Hoffman, Princes of Ireland, Planters of Maryland: A Carroll Saga, 1500-1782 (Chapel Hill, NC: University of North Carolina Press, 2002), 37.

6o Pyne, "Maryland Catholic Community," 149. 
grudgingly. "But I intend (God willing) to put all the Rubs I can, in their way."61 In the end, it was from England rather than from St. Mary's City that the "rubs" came. After William's death in 1702, the new monarch, Anne (1665-1714, r.170214), tightened enforcement of the penal laws. The era in which Catholicism openly flourished was over.

\section{$11 \quad$ Penal Era}

A 1704 act banned public Catholic worship in the colony once meant as a refuge for the faith. The effect was to render Maryland's Catholicism more like England's. Jesuit manors served as locations for Mass; services were held twice per month, if not more often, and Jesuits also offered meals, beds, and catechism to those who came. Characteristically, Jesuits described the restrictions they now faced in Maryland as a useful trial that would heighten their devotion to God. "Happy are those who suffer persecution for justice sake!" wrote one. "Rejoice therefore \& be exceeding glad to suffer in this life that you may have your reward in the next." It was not quite a white martyrdom, let alone a red, but Jesuits found meaning in what might otherwise be seen as a loss of influence and authority. ${ }^{62}$

Jesuits also, as they so often had before, established new missions, beginning to labor in Pennsylvania during the first decades of the eighteenth century. Catholic Marylanders had made their way to the Quaker colony, whose tolerant policies toward religion proved more hospitable than Maryland's. In 1729, Joseph Greaton (1679-1753) became the first Jesuit assigned to Pennsylvania, and four years later he oversaw the building of a chapel, St. Joseph's, in Philadelphia. In 1741, the English province used recently received legacies to finance the assignment of Theodore Schneider (1703-64) and William Wappeler (dates uncertain) to the colony, and seven German-speaking Jesuits followed. By 1757, St. Joseph's had almost four hundred congregants, the majority German-speakers. Pennsylvania's Catholic population grew to about six thousand by 1765 , with six Jesuit churches, including two in Philadelphia. ${ }^{63}$

Back in Maryland, Jesuits and the colony as a whole were becoming increasingly dependent on enslaved labor. As tobacco became less profitable, it was

61 Quoted in Pyne, "Maryland Catholic Community," 169.

62 Tricia T. Pyne, "The Politics of Identity in Eighteenth-Century British America: Catholic Perceptions of Their Role in Colonial Society," U.S. Catholic Historian 15, no. 2 (1997): 1-14, quote at 10.

63 Curran, Papist Devils, 197-99; Sister Blanche Marie, "The Catholic Church in Colonial Pennsylvania," Pennsylvania History 3, no. 4 (1936): 240-52. 
more difficult to attract indentured servants, and that development coincided with a drop in the price of enslaved people, making purchasing a lifetime of labor a grotesquely desirable proposition. By 1720 , so many people had been imported that one-fifth of the population of the colony was enslaved. Catholics constituted less than ten percent of the population in the first decades of the eighteenth century, and the majority of those owned no property, with many being tenant farmers. Nonetheless, a tiny and visible group of Catholic families sat atop Maryland's economic life, and their wealth came from slavery. Charles Carroll of Carrollton (1737-1832) owned hundreds of people, and the Society of Jesus over one hundred. What was life like for those enslaved by Jesuits? Twenty-first-century historians, spurred in part by Jesuits' own determination to learn about this past, are combing archives to find out. Catholic slave-owners may have been more likely than Protestant slave-owners to expose those they enslaved to their faith; one Jesuit, Joseph Mosely (1737-87), included more than two dozen enslaved people in his accounting of people he believed he had brought to Catholicism. Records suggest enslaved people sometimes comprised the majority of the congregation. ${ }^{64}$

Jesuits' attention to enslaved people's sacramental life coexisted with physical coercion, expropriation of labor, and, of course, the overarching injustice of enslavement itself. Jesuits believed themselves to be gentler slave-owners than other Marylanders, and there is some evidence that Jesuits hesitated to separate members of enslaved families through sale. Yet, there is also incontestable evidence that Jesuits harshly punished enslaved people. They sought, even if they did not always succeed, to extract sufficient labor from them to render plantations self-sufficient if not profitable. And enslavement is an absolute condition, whatever small kindnesses may be bestowed. Yet, Jesuits imagined their ownership of slaves as itself a cross to bear. Maryland Jesuits' portrayal of their slaveholding as a burden is a distinctive manifestation of a Catholic sensibility that valorized suffering. It also emerged from what one scholar calls the "ineradicable mixture of social paternalism and racism with which the Jesuits regarded" those they held in bondage. ${ }^{65}$

The colony was growing; Maryland's Jesuits had settled into their roles as planter priests. Then around 1714 came an unexpected development: Benedict Calvert, the future Fourth Lord Baltimore (1679-1715), converted to Anglicism.

64 Maura Farrelly, Papist Patriots: The Making of an American Catholic Identity (New York: Oxford University Press, 2011), 152-53; Curran, Papist Devils, 177.

65 Murphy, Jesuit Slaveholding in Maryland, quote at xxii. Tricia T. Pyne offers an extended effort to understand the extent and severe limits of enslaved people's choices as members of a Catholic community in "Ritual and Practice." 
By doing so, he gained considerable influence at court and, after assuming his title, was granted a renewed proprietorship. He did not use that influence-as some of Maryland's Catholics hoped - to argue for restoration of the colony's policies before the penal era. On the contrary, Calvert persuaded British officials to appoint a royal governor who proposed to enact additional penal laws and to look into rumors of a Jacobite conspiracy involving the colony's Catholics. (Irish servants had fired two of Annapolis's cannons in honor of the Old Pretender's birthday while other Jacobites toasted him.) Catholic efforts to plead their case with the new proprietor failed resoundingly. One of the colony's most prominent Catholics, Charles Carroll (1661-1720), refused to abjure Stuart claims to the throne, further infuriating authorities. In 1718, the Maryland Assembly stripped Catholics of the franchise.

Weakened and thwarted but not stripped of their confidence, Maryland's elite Catholics petitioned for their rights. Because British officials were determined that the colony be harmonious and profitable, they did not pursue all of the aggressive anti-Catholic policies that some Protestants urged. ${ }^{66}$ At midcentury, Catholic clans such as the Carrolls still possessed wealth and social prominence. Yet their rights within the polity were severely constrained and their status felt precarious.

In 1754, a conflict broke out that transformed North America. Like so many other conflicts of the era, the French and Indian War (1754-63) was both intensely local and profoundly global. Fighting began in the Ohio Valley, spread throughout French possessions in North America, then into Europe and the Caribbean. France's initial successes were eclipsed by England's growing dominance; in New France, the fortress of Louisbourg fell in 1758, and Quebec, the next year. Jesuits fled the capital for refuge in a Huron mission.

In Maryland, the war heightened animosity toward Catholics; a bill was put forth that would have forbidden Maryland's Catholics from educating their children abroad, seized Jesuit property, confiscated Catholic arms and ammunition (beyond what was deemed necessary to defend their households), and harshly regulated the Jesuits. In 1756, a proposal to tax Catholics doubly in order to support the war was passed and, despite assertive Catholic appeals, signed by the governor and proprietor.

In 176o, the garrison at Montreal surrendered. When the war ended in 1763, Great Britain had acquired all French territory east of the Mississippi River. But Jesuit missions faced a threat that would prove more devastating than British guns. 
During the second half of the eighteenth century, the growing international ambition and military power of Europe's Catholic monarchs provoked conflicts that affected Jesuits laboring throughout the Spanish, English, and French empires. Mistrust of the Jesuits - an organized, multilingual band of priests loyal to the pope and inclined to define what that loyalty required by the light of their own judgment—was long-standing. That mistrust was evident not only among non-Catholics but also among other Catholic orders and members of the episcopate. The Bourbon monarchs' determination to increase control over their realms intensified scrutiny of the Society.

Spanish possessions in the Americas had long been an important source of tension in the relationship between crowns and the Society. Philip II (1527-98, r.1556-98) had initially been wary of allowing Jesuits to establish missions in Spanish possessions, concerned about the priests' potential to become a rival source of authority. Once they did begin missions in the colonies, Jesuits engaged in endless disputes over monies owed to the church, harming relations with prelates.

Beginning in the early 1740 os, a Portuguese aristocrat and officeholder, the future marquis of Pombal (1699-1782), became determined to elevate his country's standing among the European powers. He was particularly eager to protect Portugal's overseas possessions, which provided more than half of state revenues. As a minister to the king in the early 1750 os, Pombal saw Jesuit missions in the Amazon as a threat to Portuguese frontier expansion. The Jesuits, Pombal concluded (with some evidence), were agents of the Spanish Empire. That belief-in combination with Enlightenment ideals favoring an expansion of state sovereignty over the traditional powers and privileges of the Catholic Church—resulted in Pombal's 1759 expulsion of the Jesuits from Portugal and its territories. ${ }^{67}$ Two years later, an elderly Italian Jesuit was led, a prisoner of the Inquisition, before a crowd in Lisbon. He was strangled, his body burned, and his ashes thrown into the Tagus.

It was just the beginning. Jesuits in Spanish and French territories were accused of serving foreign powers-or themselves-rather than the empires in which they worked. In France, the Jesuits ran afoul of Madame de Pompadour (1721-64) and also faced the pressures of bankruptcy; the superior of the French mission in Martinique (as well as the missions in Central and South America) had borrowed heavily in an effort to wring money from plantations,

67 Kenneth Maxwell, "The Spark: Pombal, the Amazon, and the Jesuits," Portuguese Studies 17 (2001): $168-83$. 
then suffered the loss of twelve of thirteen ships laden with produce for sale. In the early 176os, parlements throughout France banned the Society. Two years later, twelve Jesuits in the vast territory of Louisiana learned that their schools would be closed, their vows voided, their cassocks cast aside, and their property sold. The priests - with the exception of one older Jesuit with no relatives in France-returned to Europe. ${ }^{68}$ In 1764, Louis XV (1710-74, r.1715-74) dissolved the Society throughout the empire.

In New France, the fate of the Jesuits became entangled with negotiations at the end of the Seven Years' War (1756-63). Such had been the changes wrought over the course of the century that the British government was now less vexed by the Jesuits than were the Catholic Bourbon monarchs. British negotiators proposed that Jesuits be forbidden to accept new members but not be suppressed in their American possessions; a Jesuit in Canada wrote to a confrère in Maryland that "the practice of religion is as free as it has ever been." Jean-Olivier Briand (1715-94), bishop of Quebec, negotiated with British officials who proved willing to tolerate the Catholic Church in Canada and the Society of Jesus along with it; rather like the Society itself, the empire found flexibility served its purposes better than rigidity. The Society was never suppressed in Canada, but the last Jesuit died in 1800 , tended by Ursulines. ${ }^{69}$

Charles III of Spain (1716-88, r.1759-88) ordered the expulsion of the Jesuits from his realm in 1767. Jesuits had been accused of inspiring a riot; as was the case elsewhere, Jesuits were more generally thought to threaten the monarch's control over his people and territories..$^{70}$ That summer, the governor of Sonora received a decree ordering the expulsion of all Jesuits from New Spain. Thirty-one Jesuits were brought painfully to the coast and kept under guard for nine months under grueling conditions. At last sent to Europe, some faced continued imprisonment.

The Society of Jesus had never enjoyed formal standing in the British North American colonies. No bishops were there to promulgate the pope's suppression decree. The priests themselves dissolved their community in a final act of collective obedience and waited to see what would happen next.

68 Raymond Schroth, "Death and Resurrection: The Suppression of the Jesuits in North America," American Catholic Studies 128, no. 1 (2017): 51-66, here 54-55.

69 John Meehan, S.J., and Jacques Monet, S.J., "The Restoration in Canada: An Enduring Patrimony," in Jesuit Survival and Restoration: A Global History, 1773-1900, ed. Robert A. Maryks and Jonathan Wright (Leiden: Brill, 2015), 386-98, here 389-92, quote at 389 .

70 Magnus Mörner, "The Expulsion of the Jesuits from Spain and Spanish America in 1767 in Light of Eighteenth-Century Regalism," Americas 23, no. 2 (2004): 156-64. 
When word spread of Pope Clement XIv's plan to suppress the Society of Jesus, one Maryland-born Jesuit living in Europe made plans to return to a home he had not seen for decades. John Carroll had left Maryland while still an adolescent, studying first at St. Omer's and then at Liège, before being ordained in 1761. He taught theology and philosophy and took final vows as a Jesuit in 1771. Carroll believed Clement to be a weak pope who had not defended the Society or church against European monarchs' demands, and he found the destruction of the institution to which he had devoted his life crushing. Yet he remained faithful to the Catholic Church, and in 1774, he sailed to Maryland a reluctant secular priest.

Many Maryland Catholics—including Carroll's cousin Charles (1737-1832), who would sign the Declaration of Independence-favored the patriots' cause. Having long practiced their faith in a distinctive and largely self-sufficient way, and having long blamed Britain for the civil restrictions they faced, Catholic Marylanders did not fear a break with England. Instead, they hoped independence would bring full inclusion in the polity and economy. After a period of disorder at the war's start, Charles Carroll helped to turn the Maryland convention toward independence in the summer of 1776 . After voting to declare Maryland's independence on July 3, the convention selected Carroll as one of its delegates to the Second Continental Congress. He arrived in time to sign the declaration in early August. Carroll was the only Catholic to achieve that distinction. But Maryland's Catholics were in the main patriots, and many served in government, militias, and the Continental Army during the war.

Pennsylvania's Catholics displayed more diversity in their choices. Most were of German descent, and historians believe that the greater part were either loyal to the crown or neutral. A significant number of Irish Catholics were loyal as well and formed the majority of those who joined the Roman Catholic Volunteers, organized by an Anglo-Irish Catholic named Alfred Clifton (dates unknown) in service of the British cause. ${ }^{71}$

In the colonies as a whole, Catholics were understood to have served the patriot cause in equal or greater proportion to Protestant colonists. The revolution also found a Catholic monarch aiding colonists in the struggle against their Protestant king. As would be the case in American wars to come, Catholics felt they had proved their loyalty through their service, and they did enjoy expanded civil liberties during the revolutionary and early national eras. Virginia's 1776 Declaration of Rights stated that "the Duty which We owe to our

Curran, Papist Devils, 264-67. 
Creator, and the Manner of discharging it, can be directed only by Reason \& conviction $[. .$.$] and therefore that all men should enjoy the fullest Toleration$ in the Exercise of Religion." Pennsylvania and Maryland included all Christians in their guarantees of religious liberty, as did Massachusetts and Connecticut, though they maintained an established church. It is true that Catholics continued to be banned from holding office, and in some states, test oaths persisted into the national era. Nonetheless, the new nation held out the promise of full inclusion in the polity.

Confident that Catholics had proved their patriotism and aware of his own good standing among the nation's leaders, John Carroll believed American independence would create a country in which Catholicism might thrive. The year that delegates signed the Treaty of Paris (1783) establishing the terms of American independence also found Carroll and confrères creating the Select Body of the Clergy, an institutional successor to the suppressed Jesuit community. The select body was designed to be representative in nature and practical in its duties, meant to carry Jesuit charism and property through to a hoped for restoration. Three districts that together comprised Maryland and Pennsylvania would each send two representatives to the organization's meetings; the organization would oversee management of what had formerly been Jesuit properties. ${ }^{72}$ Once the Select Body was incorporated by the Maryland legislature, the Corporation of the Roman Catholic Clergymen became the property-holder, with its trustees as its agents. The organization neatly melded American respect for the importance of property with the institution of slaveholding, which turned people into property: it drew most of its revenues from plantations.

Even as the former Jesuits sought to preserve their corporate identity, John Carroll devoted himself to convincing Rome to create an American See. He believed the country urgently needed a bishop who could build a church suited to American circumstances while concordant with Catholic doctrine. That person, Carroll and his fellow former Jesuits agreed, should be John Carroll himself. As he worked to summon a see into existence, Carroll sought to convince his countrymen that Catholicism was simply another form of Christianity, one that entailed no unpatriotic loyalties and demanded no authority over nonCatholics. At the same time, he turned anti-popery to his advantage, reminding Roman authorities that the imposition of an inappropriate bishop-or even a refusal to use the kind of collaborative process in selecting the first

72 Robert Emmett Curran, Shaping American Catholicism: Maryland and New York, 1805-1915 (Washington, DC: Catholic University of America Press, 2012), 14-16. 
bishop that Carroll recommended —-might rouse the dangerous prejudice that Anglo-American culture had long harbored. ${ }^{73}$

In 179o, Carroll's patience and labors bore fruit; he was made bishop through a process concordant with both Catholic tradition and an American and Jesuit respect for election. As the nation's first and for a time only bishop, Carroll worked to craft an orthodox but irenic American Catholicism. The faith, he assured his countrymen, did not "keep her votaries in ignorance" nor prevent anyone from being "a candid inquirer in matters of religion." ${ }^{74}$ Carroll also valued the First Amendment's assurance that the United States would establish no religion. Carroll saw the American constitutional system's refusal to establish any single religion as a positive good, not simply something to be endured until a Catholic polity could be established.

Whatever the advantages of the nation's legal regime, Carroll also knew that American Catholics were dispersed, priests few, and Protestant neighbors skeptical. The nascent church needed clergy who could work within its distinctive circumstances and with its distinctive people. By the time of his investiture, Carroll was deeply involved in creating a school that he hoped would serve as "a nursery of future clergymen." In addition to a seminary, Carroll's institution was to contain a college that would educate boys as young as twelve, in the practice common to the era. Protestants as well as Catholics were welcome; Carroll did not believe an exclusively Catholic school necessary to the spiritual health of Catholic children and in fact believed that self-segregation courted mistrust. Carroll's creation, Georgetown, enrolled its first student in 179 o $^{75}$

As he fostered Georgetown's growth, Carroll turned to brethren in England for advice, funds, and personnel — and he received plenty of advice. Chronically short of money and priests, Carroll struggled to find instructors and had constantly to weigh the needs of the present (the nation's Catholics had few pastors) against those of the future (a growing population needed a seminary to carefully and thoroughly train priests). Carroll also believed that women religious were essential to the growth of the church, particularly given the low numbers of clergy and the ignorance of many American Catholics about their faith. After seeking unsuccessfully to attract an Ursuline community to the

73 Catherine O'Donnell, "John Carroll and the Origins of an American Catholic Church, 1783-1815," William and Mary Quarterly 68, no. 1 (2011): 101-26, here 113-14.

74 John Carroll, An Address to the Roman Catholics of the United States of America (1784), 7; https://collected.jcu.edu/cgi/viewcontent.cgi?article=1002\&context=books (accessed December 12, 2019).

75 Robert Emmett Curran, The Bicentennial History of Georgetown University: From Academy to University, 1789-1889 (Washington, DC: Catholic University of America Press, 1993), $1: 1-3$. 
new nation and even to draw an existent cloistered community into active life, Carroll encouraged the creation of the first American sisterhood, Elizabeth Seton's (1774-1821) Sisters of Charity of St. Joseph. ${ }^{76}$

The American Catholic Church drew in all its works from wealthy donors and from the plantations now owned by the former Jesuits' corporation. Lacking state support or aristocratic patrons, the American church, Carroll had explained to Rome, was "supported [...] by the farms which the first missionaries acquired by purchase and transmitted to their successors." ${ }^{77}$ Those who owned slaves on the church's behalf insisted that they had no choice but to accept the evil of slavery in order to do good, and they believed that their pastoral care of enslaved people significantly ameliorated the cruelty of the institution. As was the case earlier in Maryland's history, there is some evidence that the former Jesuits could be reluctant to separate families, but there is also evidence of the inevitable brutality of the institution. A priest in charge of a Jesuit plantation during the early nineteenth century complained that he was restrained from extracting more profit not by Christian charity but by slaves' determination to defend themselves from the lash. And when in 1805 the Jesuit corporation found itself facing a shortfall, Carroll wrote that "the sale of a few unnecessary Negroes, three or four, and stock would replace the money."78 Slaveholding became increasingly controversial in the global Society as the century progressed, and even within the American church, some clergy voiced unease. But it was an unease that brought no action. "I sincerely regret that slaves were ever introduced into the United States," one Jesuit wrote, "but as we have them, we know not how to get rid of them." This self-exculpation linked the former Jesuits to their non-Catholic countrymen. "Americans had "the wolf by the ear, and we can neither hold him, nor safely let him go," Thomas Jefferson (1743-1826) famously declared. ${ }^{79}$

76 Catherine O'Donnell, Elizabeth Seton: American Saint (Ithaca, NY: Cornell University Press, 2018), 227-29.

77 John Carroll to Cardinal Leonardo Antonelli, August 5, 1789, in The John Carroll Papers, ed. Thomas O'Brien Hanley (Notre Dame, IN: University of Notre Dame Press, 1976), 1:376.

78 John Carroll to Francis Neale, November 12, 1805, in Hanley, Carroll Papers, 2:497.

79 Murphy, Jesuit Slaveholding in Maryland, 53-55; Robert Goodloe Harper, “Appius's Letters," quoted in Eric Papenfuse, The Evils of Necessity: Robert Goodloe Harper and the Moral Dilemma of Slavery (Philadelphia: American Philosophical Society, 1997), 11. 
It was not Georgetown's efforts-which were faltering - to train priests but rather events in Europe that brought the United States a significant number of new clergy: priests fleeing the violent anticlericalism of the French Revolution found refuge in the United States. Most important to Carroll were members of the order of Saint Sulpice; the Sulpician superior, Jacques André Emery (1732-1811), and Carroll hoped that these educated priests would nurture America's nascent Catholicism, while the country would in turn protect this seedling of French Catholicism until France was safe for its replanting. Immigrant Sulpicians quickly established St. Mary's seminary just west of Baltimore, and although many former Jesuits mistrusted the new arrivals, Carroll admired their erudition and energy. One, William Dubourg (1766-1823), briefly led Georgetown. Others helped to build Seton's religious community in Emmitsburg and served as bishops in the expanding institutional church. ${ }^{80}$

The first decade of the nineteenth century found Carroll working with Sulpicians, former Jesuits, other immigrant and newly ordained priests, laity, and women religious as he sought to plant a viable Catholicism in the new nation. Carroll remained hopeful that the Society would be restored and convinced that the Jesuit order as he had known it was a true servant of the church. But he doubted that the aging men vying for control of property truly upheld Jesuit tradition, and he developed an exacting view of what restoration must look like. In his view, the Jesuit order could only be brought back into existence in the same way it had been suppressed: by direct command of the Holy See. When others contemplated alliance with fragments of the order that had escaped suppression, such as the Society in Russia (which had been protected by Catherine the Great [1729-96, r.1762-96]), Carroll hung back. Not only did he consider a papal directive necessary according to canon law, but he also was increasingly wary of hitching the Society to political authority, no matter how benevolent it might at the moment seem. The specter of revolutionary France did not make Carroll eager for the protection of a monarch such as Catherine. On the contrary, the combination of the Bourbon-inspired suppression of the Jesuits and the French Revolution's Civil Constitution of the Clergy left Carroll horrified at the thought of any entanglement of state power and church authority.

Not everyone agreed. In the last decade of the eighteenth century, former Jesuits in England and the United States considered joining the Russian

8o Michael Pasquier, Fathers on the Frontier: French Missionaries and the Roman Catholic Priesthood in the United States, 1789-1870 (New York: Oxford University Press, 2010). 
Society. Others followed the emergence of small European groups claiming to be the bearers of Jesuit tradition. The Company of the Faith of Jesus, founded in Italy by a young man named Nicholas Paccanari (1786-1811), attracted admiration and allegiance from English and European ex-Jesuits attracted to his charismatic faith and desperate for community. When ex-Jesuits in the United States met to discuss joining the Paccanarists, they did not invite Carroll to the meeting. Perhaps in response to this snub, Carroll sought more direct control over the corporation, and succeeded (whether through his brethren's continued respect or their lack of alternatives) in being elected to the corporation's board in 1802 . Carroll served on it until his death, yet never found a way to realign the interests of ex-Jesuits and church.

In that same year of 1802, Carroll learned that Pius VII (1742-1823, r.18oo-23) had authorized the Russian Jesuit order to admit former members living elsewhere. This was the kind of direct statement Carroll had waited for, and he sought permission of the Russian superior general, Gabriel Gruber (1740-1805, in office 1802-5), for American ex-Jesuits to join. Carroll himself did not join and neither did his coadjutor, Leonard Neale (1746-1817). Five other former Jesuits did. Demonstrating the intricate chains of command that characterized the church in the United States, it was Carroll as bishop and not as member who appointed the American group's superior, Robert Molyneux (1738-1808).

For the remaining twelve years of his life, Carroll, now an archbishop, struggled to reconcile the desire of members of the partially restored Society to create a novitiate (one was established at Georgetown in 1806) and guide young men through the long formation process, with the immediate need for priests to serve the nation's growing and dispersed population of Catholics. Carroll increasingly seemed to think the legacy of the Society lay in an internalized ethos that might serve the church as a whole, rather than in the resourcehungry group associated with the Russian order. Becoming less diplomatic as he aged, Carroll sent Molyneux's successor as superior, Charles Neale (17511823), a catalog of the ways that Neale, too, was failing to align the Russian Society with the needs of American Catholicism. Amid such disputes over ecclesiastical authority, some priests in the United States pointed to continued Jesuit corporation slaveholding as evidence of the community's corruption. After years of serving as pastor and prelate, Carroll—approaching eighty years old-wearied.

Then, in 1814, astonishing news arrived. A letter from Carroll's old friend Charles Plowden (1743-1821) brought word of the Society's restoration. True to form, Carroll responded with great emotion constrained by the need for action: he sent the brief on to others "even before I could nearly finish the reading of it." Carroll wondered what restoration could mean after so many years 
in the wilderness and wrote earnestly of the "propriety and necessity of much caution, which arises from the political institutions of this country," and of the "danger of opposition, and misrepresentation, proceeding [...] from the body of the Clergy," most of whom had no association with the Jesuit order. Carroll also cautioned against "the proposal of withdrawing those, who are employed in the care of souls, to bring them back to the exercises of a community life." 81 Although he set forth his vision of what was needed, Carroll knew he would not bring it to fruition. He died in 1815 , the reanimation of the Society in the United States falling to others.

\section{A New Society}

At the time of the restoration, fewer than thirty Jesuits lived in the United States. Some were survivors of the original order, others novices or members of the Russian order. Some belonged to the corporation in Maryland; others belonged only to the Society of Jesus. Conflicts over governance, over property — as just one example, archbishops battled for twenty years with the restored Jesuits over whether the Jesuits would reinstate an annual stipend granted to Carroll and his immediate successor - and over how to reanimate the Society were inevitable. So were disagreements over how Jesuits should live within the United States' pluralist democracy. During the 1820 os and 1830 os, some Jesuits hewed to an integrationist style of Catholicism that contained elements of republican governance and was compatible with Carroll's vision; by mid-century, an ultramontanist Catholicism mistrustful of republics and of the separation of church and state that Carroll had valued came to dominate. That second vision was borne by immigrant Jesuits, their presence in the United States a testament to the global challenges the order faced. As it grew, the Society provoked renewed hostility from governments, Protestants, and some faithful Catholics. During the nineteenth century, the Society would be expelled from every Catholic European country save Belgium, and from many Latin American countries, as well. ${ }^{82}$ Many of those exiles made their way to the United States.

Jesuits were shaped but not daunted by the opposition they faced. (Some seemed to revel in it.) As the United States pressed westward, opening

81 John Carroll to Giovanni Grassi, December 27, 1814, in Hanley, Carroll Papers, 3:310-11.

82 Raymond Schroth, The American Jesuits: A History (New York: New York University Press, 2007), 58-59; Anthony J. Kuzniewski, "Francis Dzierozynski and the Jesuit Restoration in the United States," Catholic Historical Review 78, no. 1 (1992): 51-73. 
opportunities for settlers and disrupting native cultures, Jesuits were there. They arrived in growing numbers in the nation's burgeoning cities, often immigrants among immigrants, increasingly molding a Catholicism nearly as different from the Maryland tradition as the Maryland tradition had been distinctive from New France or the Pimería Alta. Throughout the nineteenth century, members of the restored Society, not least in the United States, came to interpret their vow to defend the papacy as a call to protect the church against modernity and against change itself. ${ }^{83}$

The restoration and improvements in communication meant that Jesuits in the nineteenth-century United States were meaningfully part of a global (or aspirationally global) community. In 1829, the Society of Jesus elected a new superior general, Jan Roothaan (1785-1853, in office 1829-53). Determined to reinvigorate the spirituality and discipline of the Society, Roothaan prepared a new translation of Ignatius's Spiritual Exercises and wrote a manual for Jesuits undertaking them. The Spiritual Exercises were to be the wellspring of the restored Jesuits' active spirituality, and the Ratio studiorum - a plan of study adopted in 1599, which set forth theology, philosophy, Latin, and Greek as the building blocks of Jesuit education - was to provide the architecture of Jesuit schools and colleges. ${ }^{84}$

In the twentieth century, scholars would observe that the paucity of Jesuit texts available during these years had augmented the Society's already strong tendency toward conservatism. But Roothaan seems to have wanted Jesuits to be sustained and invigorated by their past, not trapped within it. The Ratio was revised in 1832, with more time allotted to mathematics, natural sciences, history, geography, and modern languages. Roothaan also authorized a crucial practical change: in 1832, Jesuits in the United States received permission to charge tuition. This served Georgetown well. The school had grown slowly in the early decades of the nineteenth century, struggling to attract students and to educate those it had: at one point, students concocted a half-baked murder plot against the young priest in training whose task it was to discipline them. But beginning in the 1830 s and ' 40 s, three Irish American Jesuits serving as president succeeded in raising enrollment and tuition revenues, improving facilities, acquiring an endowment, and turning Georgetown into a modern university. Georgetown continued to endure rebellious students as did other colleges; what became known as the Riot of 1833 included rock-throwing and arson. But the age of students gradually rose and riotous behavior ebbed.

83 John McGreevy, American Jesuits and the World: How an Embattled Religious Order Made Modern Catholicism Global (Princeton: Princeton University Press, 2016).

84 Schroth, American Jesuits, 58 . 
Few students entered either the ministry or the priesthood-less than ten percent of those who graduated between 1830 and $186 \circ .{ }^{85}$ Yet the college was on solid footing.

As Georgetown's reputation rose, so did its debts. In the late 183os, the school's leaders, including President Thomas F. Mulledy (1794-186o), came to a shocking decision: they would sell the three hundred people the Maryland province owned. Slaveholding was widespread in the American South, and the Society was not the only order to participate in the institution. Nonetheless, Jesuits' slaveholding had grown increasingly controversial. Some, including in the worldwide Society itself, now believed that slaveholding violated church teachings. American Jesuits tended to express more practical concerns; some believed that enslaved people made poor servants - bad of character and inefficient as labor-and were less amenable to pastoral care than the immigrant Catholics whom Jesuits now thought should be their focus. Leaders of the Society including Georgetown's Mulledy also looked forward to a future focused on educating city-dwellers, not managing southern plantations. As early as 1814, Jesuits had tentatively planned to sell their slaves to masters who would "prepare them" for freedom and then manumit them. In 1838, however, Maryland's Jesuits simply sold all of those they had enslaved to owners in Louisiana, known to be a harsh destination for those in bondage.

The sale produced money to pay off debts and to settle the long-running struggle over annual stipends for Baltimore's archbishops. ${ }^{86}$ The sale also extricated the province from what had come to be recognized as the immorality of slave ownership. But it did so in the cruelest possible way: enslaved people "were dragged off by force to the ship," one appalled Jesuit wrote. Roothaan had approved the sale, but Jesuits in Europe recoiled and so did some in the United States; the latter did not deplore the institution as a whole but believed that the enslaved would suffer under new owners in a way they had not under the Jesuits themselves. As disgust at the sale spread, the president of Georgetown was summoned to Rome to explain himself. Reassigned to Nice, Mulledy never returned to the college. ${ }^{87}$

That ugly end to an ugly chapter made clear a transition already underway: the American Catholic Church was no longer an institution concentrated in the plantation South. American Jesuits in Missouri, Alabama, and Louisiana

\footnotetext{
85 Curran, Bicentennial History of Georgetown University, 1:211-12.

86 Curran, Shaping American Catholicism, 28.

87 Murphy, Jesuit Slaveholding in Maryland, 162-65; Michael Pasquier, "Though their skin remains brown, I hope their souls will soon be white': Slavery, French Missionaries, and the Roman Catholic Priesthood in the American South, 1789-1865," Church History 77, no. 2 (2008): 337-70.
} 
would continue to own slaves until the Fourteenth Amendment abolished the institution. But Jesuit energy had turned elsewhere. Jesuits were founding missions in the West, where they labored among indigenous peoples exposed to the restless power of the expanding United States. They ministered to immigrants, the majority from Ireland and Germany, whose numbers began to swell in the 1830s, reaching sixty thousand per year in 1832 and 234,000 in 1847. By 1840, there were 66o,ooo Catholics in the United States, and by 1860 , when there were over three million, Catholics comprised the largest religious denomination in the country. 88

In America's growing towns and cities, Jesuits created schools, colleges, and parishes that served the immigrants and knit them into a Catholic culture within the larger United States. It was all part of what historian John McGreevy has called a "dense network of Catholic institutions to shelter the faithful from potentially hostile influences." 89 That hostility was growing. The poverty and cultural distinctiveness of the immigrant Irish, along with their rapid entry into urban politics, provoked particular resentment and fear. The anti-Catholicism that had receded during and after the Revolution surged. The American Party - which soon embraced the name Know Nothings - sought to make it far more difficult for immigrants to vote and dealt in crude anti-Catholic imagery and rhetoric. Yet Jesuits who created Catholic-only schools were not simply adapting to circumstance. They believed Catholic-only schools were superior and did not see mixed institutions as spiritually harmless or strategically necessary. Unlike Carroll, moreover, these Jesuits saw the American separation of church and state as a temporary situation, to be endured and perhaps even used to advantage, but not to be preferred to a confessional Catholic state.

\section{A Growing Nation and Society}

During these years, Jesuits in the United States were not in any straightforward sense "American Jesuits." Many had been born and educated in Europe, only to be driven out of their home countries. They acknowledged that the American separation of church and state afforded them protection from persecution that Catholic European societies did not at the moment provide. Yet they tended to mistrust the individualist, profit-seeking, Protestant-inflected culture in which they found themselves. They also opposed the views of those clergy who took

88 Cassandra L. Yacovazzi, Escaped Nuns: True Womanhood and the Campaign against Convents in Antebellum America (New York: Oxford University Press, 2018), xix.

89 McGreevy, American Jesuits, 13. 
a more sanguine view of the new nation's distinctive circumstances. Jesuits, for example, opposed Bishop John England's (1786-1842) efforts to seek cooperation between Catholics and public-school systems, certain that the Charleston, South Carolina bishop's nationalist loyalties and democratic ideals corroded the faith he promoted.

Some Jesuits turned American law and mores to their advantage, even as they disapproved of them. One Swiss-born Jesuit in Maine, Johannes Bapst $(1815-87)$, sued to end the use of the King James Bible in public school classrooms. Maine's Supreme Court ruled against him, and an angry mob tarred and feathered him for his efforts. But as Carroll had earlier recognized, anti-popery could be an instrument in the hands of Catholics: after shaming town leaders, Bapst collected a gold watch and an apology. Alert to the way this burst of violence shamed those who might indulge in a more genteel form of antiCatholicism, Bapst concluded that "the outcome of this incident will be extremely useful to the cause of the church in Maine."90

Jesuits saw Bapst's battles as part of a larger war. In 1845, Roothaan wrote to a friend that "Godlessness marches ahead with head erec [...]; Paris sets the vogue in France and France gives the tone to almost all the countries of Europe [...]. I believe that we are only at the beginning of our tribulations." ${ }^{91}$ Revolutionary leaders in Latin America as well as in Europe associated Jesuits with the oppressive political and cultural structures they hoped to smash; those who favored the revolutionary spirit of 1848 considered Jesuits their foes, and that included some immigrants to the United States. In fact, the Jesuits' - and Catholicism's - connection to tradition and continuity attracted as well as repelled, and the Society drew a few notable American converts to its ranks. Edward Holker Welch (1822-1904), scion of a Boston merchant family and a Harvard graduate, converted to Catholicism and entered the Society; a classmate of his, Joseph Coolidge Shaw (1821-51), also converted and became a Jesuit. But prominent American intellectuals, among them Margaret Fuller $\left(1810^{-} 5^{\circ}\right)$, rooted for the destruction of the pope's temporal authority and singled out the Jesuits for scorn. Jesuits were denounced on the floor of the United States Congress. The Italian former priest Alessandro Gavazzi (1809-89) and the New England-born Protestant minister Theodore Parker (1810-6o) gave popular lectures imploring Americans to resist Jesuit attacks on liberty. ${ }^{92}$

9o McGreevy, American Jesuits, 30-41.

91 Quoted in John L. Ciani, "Across a Wide Ocean: Salvatore Maria Brandi, S.J., and the Civiltà Cattolica from Americanism to Modernism, 1891-1914" (PhD diss., University of Virginia, 1992), 15 .

92 McGreevy, American Jesuits, 45-47; Jon Gjerde, Catholicism and the Shaping of NineteenthCentury America, ed. S. Deborah Kang (New York: Cambridge University Press, 2011), 199. 
Jesuit misdeeds were thought to include all realms of misbehavior: novels such as Eugene Sue's Le Juif errant (The wandering Jew [1844]) and its many imitators portrayed Jesuits as sexually exploitative as well as politically conniving. Jesuits also featured in the lurid imaginings of convent life that found publishers and readers during the era. (The most popular, the Awful Disclosures of the Hotel Dieu Nunnery of Montreal [1836] by Maria Monk [1816-49], inspired condemnations of Jesuits even as its claims to truth unraveled; defenders of the book's veracity decried debunking efforts as a "Jesuitical hoax" and blamed the titular author's second pregnancy on Jesuits, too.) Another novel, The Mysteries of St. Louis (first published in English in 1852) detailed political, personal, and financial skullduggery at Saint Louis University. ${ }^{93}$ Even some faithful Catholics mistrusted Jesuits. In Philadelphia, German parishioners opposed a bishop's plan to transfer the deed of a German Catholic parish to the Society, and in San Jose, California, a local priest opposed Italian Jesuits' efforts to establish a new college.

Critics considered the Society a bearer of Catholicism's most undemocratic and anti-modernist strains. They were not wrong. In contrast to other periods of the Society's history, restoration-era Jesuits tended to view science as a rival of faith and considered the American constitutional order unfortunate. These Jesuits believed that their future, and that of the church, depended on enhancing the power of the papacy, maintaining the remnants of the pope's temporal power, seeking (or at least hoping for) the establishment of governments that would ally with the church, and intensifying distinctions between Catholicism and other forms of Christianity. ${ }^{94}$

Beginning in 1849, Jesuits promulgated this distinctive vision of the church in a new way. In that year, at Pope Pius IX's $(1792-1878$, r.1846-78) request and with papal funding, Jesuits founded a journal called the Civiltà cattolica (Catholic civilization). Its first editor, a Jesuit named Carlo Maria Curci (1810-91), declared the need for a journal that would articulate and defend papal positions on religious and political matters. Roothaan was initially skeptical, pointing out that Ignatius had not wanted Jesuits to engage in politics. Pius dispensed Jesuits from that rule, and the journal began publication. Throughout the nineteenth century, Jesuits in the United States read and contributed to the Civiltà, and more than one Jesuit who had served in the United States returned to Europe and participated in the journal.

93 Yacovazzi, Escaped Nuns, 21, 24.
94 McGreevy, American Jesuits. 
In the pages of the Civiltà, the lines between theology, cultural analysis, and politics often blurred. The same blurring occurred in papal pronouncements. In 1854, Pius IX proclaimed the dogma of the immaculate conception. Its discussion of original sin was understood both as a theological statement and as a rejection of the possibility of virtuous democratic governance. This new teaching divided Catholics from other Christians, performing the same work theologically that Jesuits' founding of exclusively Catholic institutions in US cities and towns did culturally. ${ }^{95}$

For all their efforts to create a global church consistent in its practices and doctrine, Jesuits were not themselves a unified, let alone homogenous, group. The Society of Jesus had never been a completely supranational organization (recall the German-speaking priest contemplating his superior building skills in the Alta Pimería). Now, in the early American republic, differences emerged between Jesuits educated in the Anglo-American tradition and those from continental Europe. This had become evident among Georgetown faculty as early as the first decade after the restoration, during conflict over what became known as the Mattingly Miracle. Many (though not all) European-born Jesuits found the cure for an ailing Washington widow - achieved after the intervention of a Bavarian healer and two hundred people praying a novenato be evidence of divine intervention in human affairs. By contrast, skeptical British and American Jesuits-supported by Archbishop Ambrose Marèchal (1764-1828), a Sulpician — worried that public celebration of the event would prompt dismissal of Catholicism as childlike superstition. ${ }^{96}$ Quieter disagreements also simmered. Jesuit immigrants to the United States objected to the way the Society's American houses were run, complaining to the general about what they saw as lax rules regarding alcohol, daily schedules, and visitors, and deploring American Jesuits' celebration of national holidays such as the Fourth of July. These complaints found an audience; Maryland was consistently assigned European-born superiors through much of the century, American Jesuits were ordered to reestablish a daily order and observe silence at meals, and in 1879 the New York mission and Maryland province were joined and their headquarters placed in New York City by Jesuit officials who believed the union would improve religious discipline. ${ }^{97}$

\footnotetext{
95 McGreevy, American Jesuits, 112-13.

96 Cornelius Michael Buckley, Stephen Larigaudelle Dubuisson, S.J. (1786-1864), and the Reform of the American Jesuits (New York: University Press of America, 2013).

97 Ciani, "Across a Wide Ocean," 43; Robert Emmett Curran, American Jesuit Spirituality: The Maryland Tradition, 1634-190o (Mahwah, NJ: Paulist Press, 1987), 21-25.
} 
These tensions mattered, but they did not halt the Jesuits' labors or their integration of American Catholicism into an increasingly global church. One thing on which many Jesuits agreed was the importance of the Sacred Heart devotion. The devotion's modern roots lay in the visions of Marguerite-Marie Alacoque (1647-90), a French Visitation sister whose claims to have witnessed Jesus's pierced heart sparked unease among many of her fellow women religious but found support and publicity through her Jesuit confessor, Claude La Colombière (1641-82). ${ }^{98}$ Jesuits adopted meditation on the Sacred Heart as a symbol of God's infinite love and Jesus's self-sacrifice; even John Carroll, who tended to favor an interior piety over the use of Catholic material culture, defended the devotion. In the nineteenth century, the image of Jesus with his heart pierced, bleeding, and exposed appeared in tracts, prayer cards, oleographs, and stained-glass windows. Jesuits taught that, as one put it, "in all our wants we will find help in the Sacred Heart of Jesus [...] [especially in] the times of our life most charged with suffering." 99 The Sacred Heart devotion struck some critics as sentimental excess, an example of Roman Catholicism's appeal to baser emotions, and as the decades progressed, the oleograph would become a kind of shorthand for a folk Catholic piety, often a shorthand with a critical edge. ${ }^{100}$ But the devotion helped to create Catholicism's connection to people who knew suffering - a connection that was indeed emotional as well as spiritual. European Jesuits exiled in the United States because of democratic revolution and anticlericalism in their home countries counted themselves among that number.

Action as well as prayer continued to lie at the heart of Jesuits' charism, and nineteenth-century Jesuits created a network of preparatory schools and colleges that was far and away the dominant strain in Catholic higher education. Rejecting Georgetown's practice, Jesuit colleges founded in the mid-nineteenth century, beginning with Holy Cross, accepted only Catholics. Jesuits founded their institutions in cities boasting significant Catholic populations, including New York and Boston in the East; St. Louis, Milwaukee, and Chicago in the Midwest; and Santa Clara, Seattle, and San Francisco in the West. Jesuit colleges tended to be planted on foundations laid by secular clergy and in cities where women religious also labored. Bishops were often pleased to cede

98 William P. O’Brien, S.J., "Claude La Colombière (1641-82), Marguerite-Marie Alacoque (1647-90), and Devotion to the Sacred Heart," in A Companion to Jesuit Mysticism, ed. Robert A. Maryks (Leiden: Brill, 2017), 166-92.

99 Quoted in McGreevy, American Jesuits, 110-11, quote at 111.

100 James Martin, S.J., "Reviving the Sacred Heart," America Magazine (June 15, 2012). 
responsibilities for higher education to the Society, yet sometimes found themselves battling to assert authority in realms such as recruitment of novices and collections in which both bishop and Society had an interest. A Jesuit college, moreover, was often one part of a larger "religious complex" that included a parish and parochial school. In short, diocesan and Society endeavors both enriched and competed with each other. ${ }^{101}$

As they oversaw the building of new schools in the nation's bustling cities and towns, Jesuits offered a curriculum that had its roots long ago and far away. Peers at other institutions were offered training that was "secular, scientific, and technical in spirit, particularized in vision, flexible in approach, vocational in aim, and democratic in social orientation." ${ }^{102}$ Children attending Jesuit schools in American cities, however, continued to be educated along the lines of a plan set forth in the sixteenth century. Even something that was distinctive about the era - the transplantation of European Jesuits to the United Statesintensified the Society's commitment to tradition. Only two of twenty-five founding presidents of Jesuit colleges in the nineteenth century were born in the United States, and faculty often had imperfect English—-making reliance on Latin an oddly practical approach. ${ }^{103}$

The story of the Jesuit school foundings is, like everything to do with the Society, complicated; historian Philip Gleason has laid out five staging areas from which the plethora of institutions were created. But a few simple themes are apparent. One is that Jesuits labored in communities also served by women religious, and not infrequently followed in their wake. A second theme is the tension between Jesuits' ethnic and national identities and their supranational aims. A third is the presence of overlapping, competing authorities of secular ecclesiastics and Jesuit superiors. A fourth theme is endemic to the Society in all its endeavors: the question of how much to adapt to the distinctive circumstances of the mission and how much to try to pull those circumstances into compliance with a Jesuit vision of the true church.

\footnotetext{
101 Philip Gleason, "The First Century of Jesuit Higher Education in America," U.S. Catholic Historian 25, no. 2 (2007): 37-52, here 46-49.

102 Philip Gleason, "American Catholic Higher Education: A Historical Perspective," in The Shape of Catholic Higher Education, ed. Robert Hassenger (Chicago: University of Chicago Press, 1967), 15-53, here, 46.

103 McGreevy, American Jesuits, 153.
} 
As he encouraged the Jesuits to do apostolic work, Roothaan called for men willing to work with people "banished from their homes by new settlers, and driven to the western wilds."104 His language maintained the Society's traditional, Eurocentric view that indigenous peoples needed Christian evangelizing. It also rhetorically distanced the Society from the United States' quasi-evangelical rationale for westward expansion: manifest destiny. The multinational nature of the Jesuit effort in the West-with German, French, Irish, Swiss, Spanish, Canadian, Corsican, and Scottish men participating-further ensured that the native peoples among whom the Jesuits worked did not encounter Catholicism as a faith yoked to American nationalism or culture. ${ }^{105}$ Yet as Jesuits themselves learned, the Society's presence in the region inevitably formed part of - and sometimes compounded — the disruptions caused by the westward expansion of the United States.

In 1839, a group of Salish Flathead Indians from Montana traveled east. Meeting a Jesuit named Pierre-Jean De Smet (1801-73) in Iowa, they asked him to provide missionary services to their home community. De Smet had been born in Flanders and had first come to the United States at the age of twenty. For several years, he studied and then taught in Jesuit institutions. After returning to Europe during a period of ill health, De Smet returned to the United States and founded a mission in Iowa. He had grown incensed by the lucrative and destructive sale of alcohol to native peoples, and he was more than willing to serve as a missionary in a region he imagined to be less corrupted by American influence.

De Smet, two other Jesuit priests, and three lay brothers set out from Missouri accompanied by a famous native American guide and his family, six French Canadian trappers, and an Englishman named, somewhat improbably, Romaine. All the Jesuits were in their thirties and early forties and all were eager, as their brethren had so often been, to take on the hardships that they sensed lay ahead. One, Nicolas Point (1799-1868), was an educator and gifted artist who sketched the people and places he saw on the journey. "What joy," Point wrote on first seeing the prairies, "for [eyes] such as my own, which for twenty years had lighted on little else besides grim, college Walls! [...] At last

104 Quoted in McGreevy, American Jesuits, 30.

105 Robert I. Burns, S.J., The Jesuits and the Indian Wars of the Northwest (New Haven: Yale University Press, 1966), 54-57. 
I was face to face with fancy's ideal beauties of a missionary life!"106 The party forded the floodwaters of the Platte River, the missionaries gaining the courage to do so only after watching an Indian woman in the party ford the river along with her infant daughter. The journey held other trials, too, but the wellguided party arrived safely at the Bitterroot River, in the territory of the Salish peoples. De Smet's language recalls that of the Jesuits arriving in Maryland two centuries earlier: "We took possession of [this] promised land, by planting a cross on the spot which we had chosen for our first residence."107 Later, De Smet wrote accounts of the missions to be edited and distributed in Europe. Their purpose was similar to that of the Relations: to gain funding and political support for the missionaries' work. De Smet himself traveled to Europe nineteen times to ask for contributions, and during his trips successfully recruited young men into the Society. ${ }^{108}$ Point established St. Charles College at Grand Coteau in 1837, the only Catholic school for boys in Louisiana. De Smet also obtained money and priests, founding what would become the Jesuits' Rocky Mountain mission.

Throughout these decades, Jesuits' numbers expanded and provinces proliferated. The history of the Missouri province, the nation's second and the one in which De Smet and Point labored, gives a sense of the growth: first visited by Jesuits in 1823 , the mission, which initially extended from the Alleghenies through what became the Dakotas, became a vice-province in 1840 and a province in 1863. And from it grew many others. New Orleans became an independent mission in 1847 , then a province that encompassed Georgia, Alabama, Louisiana, and Texas. By the middle of the twentieth century, Missouri had birthed still more provinces—Chicago, Detroit, and Wisconsin—all with universities, schools, and parishes.

The middle of the nineteenth century also saw Jesuit missions growing in California and New Mexico, each sprung from a different genesis. Jesuits from northern Italy established missions in California and the Pacific Northwest. Neapolitan Jesuits founded institutions including colleges and hospitals in New Mexico, seeking to minister both to indigenous peoples and to Hispanics. Expanding their work to include Colorado, Arizona, and Texas, Jesuits in the region combated Protestantism and also sought to reform Catholic folk practices they found insufficiently orthodox. Some Jesuits in California and New Mexico

\footnotetext{
106 Quoted in Cornelius Buckley, Nicolas Point, S.J.: His Life and Northwest Indian Chronicles (Chicago: Loyola University Press, 1989), 12.

107 Pierre-Jean De Smet, Life, Letters, and Travels of Father Pierre-Jean de Smet, S.J., 1801-1873 (New York: F. P. Harper, 1904), 316.

108 Schroth, American Jesuits, 18-20.
} 
understood themselves to be (though in a way different from contemporary Jesuits) integrationist or actively supportive of cultural diversity. In New Mexico, for example, Jesuits along with other Catholics would in later years oppose the creation of a state school system, eager to preserve the Spanish-language instruction they had been part of since the nineteenth century. 109

What became the Rocky Mountain mission extended through what is now Oregon, Washington, Montana, and Idaho. De Smet and his companions imagined that they might recreate the reductions of Paraguay in the region. (Paraguay, rather than New France, was their reference.) Each mission settlement was to have a church and school in the center and to live by regulations governing worship, education, music - in short, most aspects of civic, spiritual, and social life. ${ }^{110}$ Jesuits had been invited by one group of Salish, but their efforts to establish such communities faced intense resistance from native peoples; Jesuits' vision of isolated Catholic native communities was also doomed by the expanding, restless power of the United States. Settlers relentlessly encroached on native lands, transforming the ecosystem and disrupting cultures and economies. Northern Cheyenne who had in recent centuries migrated west and become a buffalo-hunting culture, saw buffalo slaughtered by the thousands for their skins, leaving the Cheyenne world shattered. The nature of the changes brings to mind those faced by the indigenous peoples of New France, the Pimería Alta, and the Pays d'en Haut, but the pace of that change and the immediacy of the state power behind it were breathtaking. One thing had not changed: settlers brought disease, and tribes who at first hoped that European medicine or spirituality could save them quickly realized that they could not.

Jesuits in the Rocky Mountain mission evangelized using methods that would have been familiar to their brethren of centuries past. They looked for congruencies between the tribes' spirituality and Catholic teachings. Music formed part of Jesuits' religious instruction, and they hoped it would forge an emotional bond between native peoples and a larger Catholic culture. Observing that the Salish valued singing, Italian Jesuits devised songs with European melodies and lyrics in Indian languages. Italian Jesuits in the region also believed that processions, incense, and saints drew Indians into Catholicism in a way that Protestant missionaries could not achieve. Like their predecessors, these Jesuits dedicated themselves to learning native languages,

109 Gerald McKevitt, S.J., Brokers of Culture: Italian Jesuits in the American West, 1848-1919 (Stanford, CA: Stanford University Press, 1979), 8-10.

110 Gerald McKevitt, S.J., "The Art of Conversion:Jesuits and Flatheads in Nineteenth-Century Montana," U.S. Catholic Historian 12, no. 4 (1994): 49-64. 
preparing dictionaries and grammars, and analogizing Indian languages to Latin forms. Some became more fluent in native languages than they were in English. ${ }^{111}$

Although their purposes were distinct from the government's, Jesuits in the West helped to negotiate treaties, such as those between tribes and gold rushers in the Washington Territory in 1858 ; the priests sought protections for Indians and hoped to limit violence, but their efforts ensured that the tribes were confined to shrinking territories. Other Jesuits also participated indirectly in America's project of expansion; the immigrant John McElroy, S.J. $(1782-1877) .{ }^{112}$

Serving as a military chaplain was an unusual assignment in many ways, not least because it abstracted Jesuits from the larger web of vowed Catholic labor in which, during the nineteenth century, they usually worked. In almost all regions, Jesuits labored with or near women religious; often, they entered a community after Catholic sisters had already established a presence. This was true in the East, where Sisters of Charity had before 1820 established missions in cities including Philadelphia and New York; in the Midwest, where De Smet worked with Rose Philippine Duchesne (1769-1852) and other women of the Religious Congregation of the Sacred Heart of Jesus; and in the West, where Sisters of Providence founded girls' schools in Montana and Washington several years before Jesuits began their efforts. Anthony Kohlmann (1771-1836), who began his Jesuit formation in Russia before the Society's restoration elsewhere, observed the importance of sisters early in the Jesuits' American journey: he believed that three things were required for religion to thrive in an area-a boys' college, an academy for girls, and an orphanage, the latter two almost certainly the creation of women religious. ${ }^{113}$

Anti-Catholic rhetoric makes clear that even Protestants recognized Jesuits and sisters as collaborators: one writer urged Protestant parents "not [to] endanger the virtue and usefulness of your children [...] and especially your daughters [under] the management of Jesuit priests and Ursuline nuns."114 Catholic families would indeed often have had children schooled by sisters as well as boys schooled by Jesuits. Jesuit histories tend to trace Jesuit educational reforms to internal deliberations and the press of competition from other male-run schools and institutions, but it is also possible that families saw Catholic sisters' willingness to adapt girls' education and wondered why their sons' education could not also be tailored to American circumstances.

\footnotetext{
111 McKevitt, "Art of Conversion."

112 John Connolly, "Father John McElroy, S.J.: 'First' Catholic Chaplain of the United States Army," Clogher Record 20, no. 3 (2011): 535-40.

113 Gleason, "First Century of Jesuit Higher Education," 44.

114 Quoted in Yacovazzi, Escaped Nuns, 7o.
} 
What can we learn about Jesuits' collaboration with sisters? Jesuit sources tend to be less expressive on this point than the women's sources are, reflecting the institutional and social authority vested in clergy and simply in men. Historians such as Margaret McGuinness have explored the intersections of gendered and clerical authority in the lives of Catholic sisters. When Jesuits possess authority over women religious in the absence of consensus, or benefit from women religious' domestic labors on their behalf, it is not simply the women's experience of obedience and community life that is affected but the men's as well. Jesuits' collaborations with women religious and the ways their roles as clergy concatenated with their roles as men is a part of the Society's history that is just beginning to be explored.115

In the 185 os, slavery and the economy and culture it produced became the central question of American politics. Jesuits continued to enslave people in Missouri, Louisiana, and even in Maryland, where census records list slaves two years after the 1838 sale. ${ }^{116}$ For the most part, Jesuits also failed to recognize the moral and spiritual blight that slavery was. Along with other Catholic clergy, Jesuits tended to disapprove less of slavery than of abolition, considering the latter an ally of disruptive modernity and, more specifically, simply another expression of the Know Nothings' anti-Catholic views. Jesuit colleges, moreover, drew students and tuition monies from slaveholding families, including Protestant parents who favored the Jesuits' traditional, humanistic education. Fordham and Holy Cross had student bodies that were nearly one-fifth from the South, and the proportion at other institutions was higher. ${ }^{117}$

As the sectional crisis moved toward war, Jesuit-run schools and colleges witnessed the kind of arguments and ruptures occurring throughout the nation. After John Brown's (180o-59) raid on Harper's Ferry (1859), a Georgetown debating society contemplated the topic, "Should the South now secede?"

115 See, for example, Margaret McGuinness, "Why Relationships Matter: Sisters, Bishops, and the History of Catholicism in the United States," Catholic Historical Review 110, no. 2 (2014): 219-42; McGuinness, Neighbors and Missionaries: A History of the Sisters of Our Lady of Christian Doctrine (New York: Fordham University Press, 2012); Jacqueline Romero, "By the labors of our hands': An Analysis of Labor, Gender, and the Sisters of Charity in Kentucky and Ohio, 1812-1852" (PhD diss., Arizona State University, 2019).

116 Curran, Shaping American Catholicism, chapter $2(30-51)$.

117 Robert Emmett Curran, "Jesuit Colleges and the Civil War," Conversations on Jesuit Higher Education 45 (2014): 1-13, here 1. 
After two weeks, the affirmatives won. When the war began, competing Union and Confederate militias formed at Jesuit schools, including St. Xavier in Cincinnati. In Bardstown, Kentucky, St. Joseph's closed down and buildings were converted into a military hospital. Georgetown's medical school became an important training center for physicians struggling to ameliorate the carnage. But in many schools, enrollments declined due to disrupted travel and wartime inflation, as well as the military service of the small percentage of students old enough to enlist or be conscripted. One graduate of Fordham, Robert Gould Shaw (1837-63), would gain fame, though he was not immediately celebrated at Fordham itself, for his service and death leading an all-African American regiment, the 54th Massachusetts, in battle. The child of Unitarian abolitionists, Shaw had attended Fordham at the urging of his uncle, the Shaw who had converted to Catholicism and been ordained as a Jesuit priest in the 1840s. ${ }^{118}$

After the Jesuit superior general instructed American Jesuits to remain neutral, only the faculty of Spring Hill College in Alabama-ardent Confederatesopenly defied his command. But many others in one way or another let their views be known. In Missouri, where secessionists and Unionists battled for control, Jesuits privately and sometimes publicly expressed their allegiances. De Smet, then in St. Louis, was an ardent Unionist, expressing dismay at the fall of Fort Sumter: "The Stars and Stripes, the far-and-wide honored flag of the great Republic had been battered down by the enemies of the Union-once Union themselves—reduced to mere shreds, a rag! Unpardonable outrage!"119 De Smet believed he avoided discussing the war- "I am keeping my mouth shut about politics," he told a friend - but he blamed the conflict on Southerners' insistence on expanding slavery, and his Unionist sentiments were sufficiently well known to make him a favored intermediary with Washington. Alert to strategic possibilities, De Smet informed officials there that they should pay monies owed the Jesuits for their labors in western missions, lest Indians become Confederate sympathizers. Whatever the plausibility of the threat, in 1862 De Smet succeeded in obtaining payment of a large, overdue sum to the Jesuits' missions in Kansas. ${ }^{120}$

De Smet's Unionist sympathies distinguished him from many of his brethren. Faculty at St. Louis University were suspected to be a nest of Confederates. "Several of Ours without regard to the instructions of your Paternity," De Smet wrote the superior general, "continue to manifest secessionist sentiments."

\footnotetext{
118 Curran, "Jesuit Colleges and the Civil War," 2.

119 De Smet, Life, Letters, 76.

120 Gilbert J. Garraghan, Jesuits of the Middle United States (New York: America Press, 1938), 2:159.
} 
William Stack Murphy, S.J. (1803-75), the superior of the Midwestern Jesuits, was a Confederate sympathizer who wrote disparagingly of "non-Catholic Germans" taking up arms on behalf of Unionists in the state. One Jesuit, Ferdinand Helias (1796-1874), professed loyalty to the Union, but German freethinkers who had long opposed his influence accused him of secessionist sentiment. After twice going into hiding, Helias issued a public accounting of his patriotism and was offered protection by General Jefferson C. Davis (1828-79), a Union commander in the region. ${ }^{121}$

In the absence of a conscientious objector system, Jesuits were subject to conscription in both the Union and Confederate armies. De Smet worked to exempt brethren from Union conscription, explaining in writing and in person that the Society's vows meant Jesuits could not take up arms, nor, in most cases, raise funds to buy a substitute. De Smet's personal appeal to Secretary of War Edwin Stanton (1814-69), joined by that of a Baltimore Jesuit named John Early (1814-73), resulted in assurance that Jesuits would almost certainly not be called up in the Union army. ${ }^{122}$ The president of Alabama's Spring Hill College appealed to the Confederacy's assistant secretary of war and was granted a similar reprieve. Spared from combat, Jesuits served as chaplains to both Union and Confederate forces.

The end of the war brought a grotesque shock to one Jesuit institution: among those implicated in Lincoln's assassination were three alumni of Georgetown. Other schools faced something familiar in Jesuit history: the need to adapt. Fewer Southern students, whether Catholic or Protestant, enrolled at Jesuit colleges in northern and border states, leading institutions such as St. Louis University to draw more consciously from their own metropolitan areas. ${ }^{123}$ Jesuits did not yet grapple with the legacy of their participation in and support of slavery: that reckoning lay years in the future. Instead, Jesuits in the United States emerged from the Civil War into an era of growth and continued influence within American Catholicism, one that would require their powers of adaptation and persuasion just as had every other moment in their history.

The world had not stood still during the American Civil War. On the contrary, 1861 saw not only the birth of the Confederacy but the founding of the kingdom

\footnotetext{
121 Garraghan, Jesuits of the Middle United States, 2:155-66, quotes at 158, 155, 166.

122 Garraghan, Jesuits of the Middle United States, 2:160-62.

123 Curran, "Jesuits and the Civil War," 13.
} 
of Italy. That founding and the Risorgimento that followed destroyed the remnants of the papacy's temporal power and captured the imagination of Jesuits in ways that compounded the Society's post-restoration mistrust of change.

In 1864, Pius IX promulgated the Syllabus of Errors. Pius, who had been pope since the 184 os and had instigated the founding of the Civiltà cattolica, had become ever more appalled by European politics and culture. The Syllabus condemned the proposition that the church should accept democracy as the preferred form of government. It also rejected what it characterized as the belief that "the Roman Pontiff can, and ought to, reconcile himself, and come to terms with progress, liberalism and modern civilization." Sympathetic scholars have since argued that the Syllabus objected to an augmentation of state power and assault on religious expression that in the twentieth century would fuel fascism and Stalinism. But the Syllabus provided ready evidence for contemporary critics who believed that the church was fighting a losing battle against liberty and against reality itself.

Rome fell in 1870. In the same year, during the First Vatican Council (186970 ), Pius promulgated the doctrine of papal infallibility. Like the doctrine of the immaculate conception, this teaching divided Catholics doctrinally from other Christians and prompted an outcry from those who saw it as proof of Catholicism's unsuitability to the modern era. Pius also held onto the hope of regaining temporal power, turning against anyone-including the Jesuit founder of the Civiltà, who had come to believe that peace between the Holy See and the new Italian government was best for the church - who disagreed. The Civiltà, now in the hands of a new editor, was moved to Florence where it continued to oppose the modern Italian state. The journal also intensified its use of anti-Semitic language. Since its inception, the Civiltà had posited the existence of a "Jewish-liberal party" that opposed the interests of the church; now it analogized the fall of Rome to the murder of Jesus and blamed Jews for both. Articles described the Jewish people as a race with distinctive characteristics, and journalists and reformers whom Civiltà authors opposed were characterized as Jewish. The Civiltà's mistrust of nationalism and modernity would remain entangled with anti-Semitism for generations, and in later years Nazis and Italian fascists would quote its pages. ${ }^{124}$

124 Ciani, "Across a Wide Ocean"; David Lebovitch Dahl, "The Anti-Semitism of the Italian Catholics and Nationalism: 'The Jew' and 'the Honest Italy' in the rhetoric of La Civiltà cattolica during the Risorgimento," Modern Italy 17, no. 1 (2012): 1-14, here 1; Dahl, "The Anti-Semitism of La Civiltà cattolica Revisited," in "The Tragic Couple": Encounters between Jews and Jesuits, ed. James Bernauer and Robert A. Maryks (Leiden: Brill, 2014), 217-31. 
During the last decades of the nineteenth century, many of the United States' Jesuits continued to come from Europe, including Italy; the politics of most were shaped by horror at democratic revolution and anticlericalism generally and the events in Italy specifically. This perspective shaped even a project specifically designed to enhance the cohesiveness of the American Jesuit community: Woodstock College. Since the mid-nineteenth century, concern had been expressed that Jesuits in the United States, who came from and worked in many different places, lacked a sense of community. Members of the Society took courses at schools including Fordham, Georgetown, and Laval College in Canada, but there was no central place for their formation. Given that lack, and in the context of ongoing complaints that the American houses lacked religious discipline, Jesuits in Rome recommended the creation of an American theologate. One was established in Boston during the Civil War but proved ephemeral. (Boston College, on the other hand, founded in 1863, thrived.) Later that decade, after considering a site in Pennsylvania, Jesuits from the Maryland and Missouri provinces settled on a rural tract of land twenty miles west of Baltimore. The pastoral setting was designed to protect those in formation from the modern influences Jesuits deplored. A library of forty-five thousand volumes was pulled together from other institutions, and in 1869 scholastics began classes at the newly created Woodstock College. ${ }^{125}$

Woodstock grew rapidly, within twenty years billing itself as the "largest Jesuit community in the world." A journal the college published, Woodstock Letters, became a repository of musings, book reviews, analytical reports, and reminiscences - an expression and creator of community that remains an extraordinary resource for the study of American Jesuits. As is clear in the journal's pages, Woodstock was meant to be as much as possible its own world. Classes and announcements occurred in Latin, lay brothers performed tasks such as cooking, gardening, and game-keeping, and smoking and drinking were severely restricted. ${ }^{126}$

Designed to serve and unite Jesuits in the United States, Woodstock was in no way a distinctively American environment. On the contrary, most of its early faculty members were exiles from Europe whose worldview and teaching were profoundly shaped by their experiences in their home countries. Its faculty included many Italian-born Jesuits, among them Neapolitans who had faced particular dislocation and loss of status because of Italy's changing politics. As had been true for decades, immigrant Jesuits tended to look on the United States with ambivalence. Some saw it as, in the words of one Jesuit,

125 Schroth, American Jesuits, 88.

126 Schroth, American Jesuits, 88-9o. 
"perhaps the only home left us in this world." At least one hoped that mass conversions from Protestantism would make the United States a Catholic majority country, in which the church would be officially recognized as the state church. But that hope indirectly revealed a rejection of the American constitutional system, and many Jesuits - even some of those who appreciated the refuge the United States offered-indeed felt that their new home was at best an imperfect setting for the faith. One Jesuit articulated a widely held desire that Woodstock might prevent young men from "being infected by the ideas they breathe" in the United States, where "the protestant and infidel element predominates immensely." 127

Not all Jesuits shared Woodstock's ethos; in 1870, the Jesuit president of Georgetown, Bernard Maguire (1818-86), praised the Maryland tradition of "religious liberty" and opposed "the establishment on the soil of our common country of a State religion, were it our own or any other."128 Maguire was more exception than rule. Setting their faces against the growing valorization of individual rights and press freedoms, Jesuits argued that their multiple expulsions demonstrated that the Enlightenment, in tandem with the Reformation and the Age of Revolutions, had produced a new kind of tyranny, one cloaked in the language of liberty. In response, Jesuits sought to create an orthodox Catholicism immune to national boundaries, state sovereignty, and time itself.

Ever-increasing miles of railroad track, the Homestead Act of 1862 (which provided that adult Americans loyal to the United States could claim 16o acres of government land), the invention of barbed wire: all contributed to American settlers' movement west after the Civil War. Indigenous peoples resisted encroachment through many means, including arms. During the 1870s, Jesuits, many of them members not of American but of European provinces, continued to staff missions in the West. The 1870s saw Jesuits from Turin working among the Blackfeet Indians, German Jesuits working with native peoples in the Dakota Territory, and Swiss Jesuits laboring on reservations in Kansas. Some worried they were complicit in the brutal facts of American expansion. Gregorio Gazzoli, S.J. (dates unknown) worked to persuade members of the Coeur d'Alene and Spokane tribes not to join Chief Joseph's (1840-1904) military campaign against the federal government, but he blamed the government

127 Quotes in Ciani, “Across a Wide Ocean," here 81, 8o.

128 Ciani, "Across a Wide Ocean," quote at 107. 
for the uprising. Another Jesuit refused to help negotiate a treaty with the Nez Perce in 1877, explaining, "I have promised to these Indians several times never to speak to them about making their reservation smaller [...]. And I would lose a great deal of my authority, if I were to busy myself with them about such matters." In 1889, a third Jesuit in the region observed that a community of Blackfeet had no interest in his proselytizing. The Blackfeets' leader had explained to him that the priest "should not speak any longer on the matter, that they were starving, that the government should issue rations and provide them with farming implements." "This seemed pretty reasonable," the Jesuit observed. "To speak to a starving people about the way to heaven without doing anything to relieve their pressing necessities is simply provoking."129

The experiences of one Jesuit, Aloysius van der Velden (1848-1925), suggests both the ways in which work with native Americans changed individual Jesuits' views, and the inability of Jesuits to ameliorate the consequences of American expansion. Originally from the Netherlands, Van der Velden was assigned to work among the Northern Cheyenne at a mission in southeastern Montana. The tribe had been forced to move onto a reservation, then found that even there, they were subject to settlers' violence and their slaughter of the buffalo on whom the Cheyenne relied. In the early years of his work in the American West, Van der Velden wrote that he felt "stomach-turning disgust" at the customs of the people he evangelized. He found women of the tribe hostile: "Fury in the full sense of the word." Van der Velden's distaste was part of his instrumentalist view of the people he ostensibly served: "I will merit a better place in heaven here where I am, that I would have ever merited in Europe," he wrote. Blind to the fact that the Cheyenne had neither the opportunity to pursue their traditional occupations nor the means with which to take up sedentary farming, he found them "so lazy, that I doubt whether the devil wants them in hell, for they are too lazy to burn." Disturbed by spiritual practices such as the Cheyenne Sun and Ghost dances, Van der Velden tried to persuade indigenous people to abandon the dances entirely or, at a minimum, to stop taking their children out of boarding schools in order to participate. The Cheyenne resisted efforts to uproot their children from their culture just as Iroquois and Algonquin Indians had centuries earlier. ${ }^{130}$

129 Gerald McKevitt, S.J., "Northwest Indian Evangelization by European Jesuits, 1841-1909," Catholic Historical Review 91, no. 4 (2005): 688-713, quotes at 694, 708.

130 Suzanne H. Schrems, "The Northern Cheyennes and the Fight for Cultural Sovereignty: The Notes of Father Aloysius Van der Velden, S.J.," Montana: The Magazine of Western History 45, no. 2 (1995): 23-29, quotes at 22, 24. 
Gradually, Van der Velden recognized the suffering he witnessed. He also came to understand that he himself was not welcomed by the American government. The combination left him less harshly judgmental of the Cheyenne, and he was saddened when his Jesuit superior - observing that tribe members rejected Van derVelden's evangelizing — moved him to a Crow Reservation. Van der Velden found that he missed the people he had disdained and despaired of. Returned to the Cheyenne, Van der Velden worked with renewed hope, but settlers' violence against Indians continued, and so did the Cheyenne commitment to spiritual practices such as the Ghost dance. Aging and ill, Van der Velden was sent to less arduous postings, and soon died. Jesuits abandoned the mission to the Cheyenne in 1897.

Indian resistance to Jesuit proselytizing, along with growing demand for labor in the network of Jesuit schools and colleges, drained the Jesuits' Western missions of people and energy. The founding of colleges such as Gonzaga in 1887 and Seattle College in 1891, meant that the mission's traditional mottoSumus primo pro Indianis (We are [here] primarily for the Indians) — no longer held. Moreover, as the Society was allowed to return to European countries, fewer Jesuit immigrants came to the United States. Italian Jesuits turned their attention away from the United States and, by 1910, there were fewer than forty, many of those elderly and ill, in the Rocky Mountain and California missions. ${ }^{131}$

Education, Americanism, and Modernism

Jesuit energy in the United States was now unquestionably focused on education. A 1916 list created by the Catholic Educational Association would show that of eighty-four Catholic colleges for men, twenty-six were run by Jesuits; those twenty-six included the majority of schools with more than one thousand students, as well as the majority of those with significant professional and graduate programs. ${ }^{132}$ As had been the case in earlier centuries, Jesuit schools were often part of a large complex of endeavors that included the work of women religious. Now, their numbers growing, Jesuits began to conduct internal missions to English-speaking, non-indigenous Americans. The missions' first proponent was an Austrian immigrant, Francis Xavier Weninger, S.J. (1805-88). Inspired by his work among German-speaking Catholics, Weninger petitioned Roothaan and his successor, Peter Jan Beckx (1795-1887, in office

131 McKevitt, "Northwest Indian Evangelization," 710.

132 Gleason, "First Century," 38-39. 
1853-87), as well as American superiors, to dedicate men to the task of traveling to parishes to preach, catechize, and offer sacraments. ${ }^{133}$

The labors of Arnold Damen (1815-90), a Dutch priest recruited by De Smet during one of his many trips to Europe, suggests the range of possibilities during this era. After completing his Jesuit formation in the United States, Damen served Chicago's German and Irish immigrants through preaching, founding lay organizations and parochial schools, and offering the Spiritual Exercises to interested individuals and groups in missions that fulfilled Weninger's vision of a Jesuit apostolate to American parishes. Damen, who attracted criticism for practices such as charging admission for lectures and selling his books, used his proceeds to pursue his many projects. When the Great Chicago Fire (October 8-10, 1871) spared a Jesuit residence and church, Damen rejoiced that God had offered "a monument of his impeachable mercy towards us." ${ }^{34} \mathrm{He}$ gave missions ranging as far west as Wyoming, and by the time of the Civil War, had three companions in his efforts. In 1870, he founded St. Ignatius College, the predecessor to Loyola University Chicago.

In succeeding decades, a number of American provinces established "mission bands," small groups of Jesuits who traveled to parishes large and small, spending days or weeks in a parish preaching, hearing confessions, and preparing parishioners for first Communion and confirmation. Along with women religious and other male clergy, Jesuits were creating an American Catholic world. Parochial schools at some moments enrolled half of the country's Catholic children. Some non-Catholics - not least members of the Republican Party, who considered non-sectarian public education an essential part of the republic - were appalled. President Ulysses S. Grant (1822-85, in office 1869-77) inveighed against public aid to religious schools and questioned the Catholic Church's tax-exempt status.

Some also cast a skeptical eye on Catholic higher education. In 1893, Charles W. Eliot (1834-1926), Harvard's president and an educational reformer, declined to include any Jesuit or Catholic college on a list of institutions whose graduates would be admitted to Harvard Law School. Eliot denied that he was prejudiced against Catholics and could point to cordial relations with at least one prelate as evidence. But he argued that the Jesuit system of education, which lacked electives and training in the scientific method, did not produce scholars appropriate to the study of law. After protest from Catholic educators, Eliot relented, but in 1899 he published a piece arguing that inflexible curricula

133 Garraghan, Jesuits of the Middle United States; N. John Anderson, S.J., "Parish Missions and the Jesuit Ministry," Woodstock Letters 94, no. 1 (1965): 55-71, here 55-58.

134 Schroth, American Jesuits, 96-99. 
such as he believed the Jesuits used were like "the method followed in Moslem countries, where the Koran prescribes the perfect education."135

Eliot's claims did not go uncontested. A philosophy professor at Woodstock College named Timothy Brosnahan (1865-1915) issued an elegant reply, demonstrating that Jesuit education was not fixed in the seventeenth century but rather had grown to include modern languages, science, and English. Brosnahan also pointed out that Eliot's beloved elective system had only recently been adopted even at Harvard. Attractive as Brosnahan's description of the Jesuit schema was, the reality of Jesuit colleges was often ragged. Jesuits' scholarship and pedagogy were richer in memorization and superficial apologetics than in inquiry or originality. The seven-year structure mandated by the Ratio was an awkward fit with the developing four years of high school/four years of college model of American education. In 1896, Jesuits adopted a fourfour plan, but few students stayed in the combined high schools and colleges long enough to finish. In the end, however, Eliot's doubts about the Jesuit system may have been less threatening than decisions being made within Catholic families: Catholic students were increasingly turning to non-Catholic colleges, valuing the education and useful social connections they offered. ${ }^{136}$

Catholic families' growing interest in secular education highlights an important fact: as powerful and vocal as Jesuits were, they were not the only clergy presenting a vision of the faith in the United States. A second group of clergy believed that the Catholic Church could and should adapt to American circumstances, embrace pluralism and democratic values, and value public education. Proponents of this view, including Archbishop John Ireland of St. Paul (1838-1918) and Cardinal James Gibbons of Baltimore (1834-1921), believed that such a church would serve God and successfully draw converts. These prelates also tended to advocate progressive social views: Ireland was attentive to the needs of immigrants and Gibbons defended the rights of Catholic laborers. Knowing that their Jesuit adversaries possessed channels through which they influenced Roman policy and policymakers, these liberal American prelates sought their own Vatican allies.

A third figure who countered the vision of the Jesuits was not a part of the American hierarchy. Isaac Hecker (1819-88) was a convert to Catholicism who founded the Paulist fathers, an order devoted to the goal of bringing Americans to Catholicism. Through his preaching, public lectures, periodicals, and books, Hecker presented his faith as food for both mind and heart, and he strove to present Catholicism as at home in the democratic United States. "With the

135 Schroth, American Jesuits, 105-7, quote at 107.

136 Schroth, American Jesuits, 107-8. 
free exertion of Reason, with the natural impulses of our instincts, and with the silent influences of our noble institutions," Hecker wrote confidently, "the American people will rise in the strength of its manhood and proclaim itself Catholic."137 Hecker did not find the Jesuits expressive of the kind of Catholicism he felt would flourish in the United States; a visit to Holy Cross College just before his baptism left him praising the priests' "private virtues" but unsettled by what seemed to him their emphasis on "the lowest and the least that the church demands of us," rather than on "something deeper, more eternal and invisible."138 Hecker's vision, so different from the Jesuits', gained admirers not only in the United States but also in France, where some Catholic reformers viewed him as a guide to what the faith must become.

In 1883, Rome summoned American archbishops to discuss the agenda for a forthcoming plenary council. Rome hoped to contain divisions among the prelates, but disagreements over issues ranging from public schools to labor unions to the desirability of democracy continued unabated. Archbishop Ireland gave an interview with the New York Herald in which he lamented "a clique of myopic Roman Catholics [...] to whom America is a bogeyman and whose principal religious aspiration is to imprint on the Catholic Church in the United States all the details of European monarchies and empires."139 Jesuits in the United States, by contrast, warned that praise for the separation of church and state was a step toward the creation of a polity that outlawed religion entirely.

In 1887 , a new site of competition between these divergent visions of the faith was born. Catholic University was established in the District of Columbia near a home for Civil War veterans. The university was chartered by Leo XIII (1810-1903, r.1878-1903), whose call for a "critical encounter with modernity" allowed for the possibility of some good in modernity, but accorded with the Jesuits' worldview far more than the liberals.'140 But its first rector, Bishop John J. Keane (1839-1918), shared the views of Ireland and Gibbons, and so did Kean's successor, Denis J. O'Connell (1849-1927). Catholic University was soon staffed by Paulists (Hecker's order), Dominicans, and Franciscans. Its curriculum did not share the Thomism of Jesuit higher education (which Leo XIII had in 1879 endorsed as the preferred Catholic philosophical tradition), and

\footnotetext{
137 Quoted in Gjerde, Catholicism, 81.

138 Quoted in Anthony J. Kuzniewski, Thy Honored Name: A History of the College of the Holy Cross, 1843-1994 (Washington, DC: Catholic University of America Press, 2017), 5. See also David J. O’Brien, Isaac Hecker: An American Catholic (New York: Paulist Press, 1992).

139 Ciani, "Across a Wide Ocean," 164.

140 Philip Gleason, Contending with Modernity: Catholic Higher Education in the Twentieth Century (New York: Oxford University Press, 1995), 107-8.
} 
its faculty offered a liberal view of the church's proper accommodation with American society. ${ }^{141}$

The struggle over the nature and future of American Catholicism continued through the 189os, even as Jesuits continued to expand their work. That each camp sought support in Rome, as well as the tendency of the conservative group to interpret American events through the lens of Italian developments, meant that the arguments were in every way transatlantic. So too were the Jesuits associated with Woodstock. Two Jesuits who had served at the Maryland theologate, the theologians Camillo Mazzella (1833-19oo) and Salvatore Brandi (1852-1915), returned to Italy, Mazzella to serve as a cardinal and professor at the Gregorian University, and Brandi to serve on the Civiltà cattolica. They worked together to oppose liberal American prelates' initiatives. The first apostolic delegate sent to the United States, Francesco Satolli (1839-1910), also favored the Jesuits' view of the faith. ${ }^{142}$

Liberal prelates feared that their flocks might rebel against—or drift away from - the form of Catholicism that clergy such as Mazella, Brandi, and Satolli promoted. In the United States in the last decades of the nineteenth century, enough immigrant Catholics-including growing numbers of people from Southern and Eastern Europe - participated in labor unions to prompt alarm in Archbishop Ireland and Baltimore's Cardinal Gibbons at word Leo XIII was considering condemning the Knights of Labor as a suspected socialist organization. Gibbons warned that such an act risked "losing the love of the children of the church."143 In the end, doctrinal conservatism proved not to track with tenets of American political conservatism. Rather than condemn the knights, Leo issued Rerum novarum (May 15, 1891), which called on states to protect the welfare of workers and affirmed workers' right to organize. Rerum novarum had been drafted in great measure by an Italian Jesuit and contributor to the Civiltà, Matteo Liberatore (1810-92), who mistrusted the unregulated marketplace. ${ }^{144}$ The encyclical's rejection of unregulated capitalism produced a document that privileged Catholic social order over secular models but that was also, at least in the United States, politically progressive. It hinted at future grounds of reconciliation between battling Jesuit and liberal clergy. But that reconciliation had not yet begun.

\footnotetext{
141 Schroth, American Jesuits, 90-95.

142 Ciani, "Across a Wide Ocean," 40-45.

143 Quoted in John J. O'Brien, George G. Higgins and the Quest for Worker Justice: The Evolution of Catholic Social Thought in America (New York: Sheed \& Ward, 2004), 222.

144 Schroth, American Jesuits, 94; McGreevy, American Jesuits, 159.
} 
As the nineteenth century drew to a close, conservatives had reason for optimism. Mazzella - by now a cardinal leading a congregation that supervised Catholic educational institutions-participated in a successful campaign to remove Bishop Keane from his post at Catholic University. Yet liberal American prelates did not abandon the field. In 1897, Archbishop Ireland wrote to the Vatican's secretary of state to combat what he felt was the Civiltà's jaundiced and damaging view of the "Americanists" — now the term applied to the liberal prelates. O'Connell publicly praised the late Isaac Hecker and what he deemed true "Americanism," a set of ideas that in O'Connell's view did not constitute heresy but rather recognized the dignity of the individual and followed Catholic teachings. ${ }^{145}$

Brandi, another of the Jesuits who had gone from Italy to Woodstock and back, drafted for Leo XIII a document warning against practices it attributed to American clerics, such as creating a national church alienated from Rome and rejecting traditional spiritual direction. That document formed the basis for a papal encyclical Leo XIII issued in 1899, Testem benevolentiae. The encyclical cautioned against diluting doctrine in a quest for popularity, emphasized the importance of ecclesiastical authority, and pointed to the necessity of following Catholic teachings if one wished to be saved. Patriotism was acceptable, the encyclical explained, but democratization of the church was not. Learning of the encyclical before its release, Archbishop Gibbons requested its promulgation be delayed until he might argue against its premise. He insisted that no one in the United States held the "extravagant and absurd doctrine" the pope decried. Gibbons's request was denied. Testem benevolentiae marked the ascendancy of a distinctive Jesuit understanding of the faith — and a distinctive Jesuit characterization of opponents. ${ }^{146}$

The Americanist controversy was part of broader arguments in the church over the extent to which Catholicism should adapt to culture and era. Some conservative Catholics saw rising American geopolitical power-in the wake of the Spanish-American War (1898), for example - as further reason to forestall American influence inside of the global church. That same rising influenceoccurring, not insignificantly, at the expense of Spain-heartened liberal Catholics such as O'Connell, who hoped Jesuits' influence in the Philippines would decline, opening the way for a reformed Catholicism. The Civiltà sided stalwartly with conservatives in what became known as the modernist controversy, as it had done during the arguments over Americanism. Scholar John L. Ciani (1951-94) efficiently summarizes the situation at the turn of the

145 Ciani, "Across a Wide Ocean," 226.

146 Ciani, "Across a Wide Ocean," 240. 
century: "The Civiltà Cattolica and the Society of Jesus seemed only too happy to cooperate with the Vatican by leading attacks against whatever threatened ecclesiastical authority, whatever opened up the church to the modern world, and whatever called into question European domination over the administration of the institutional church."147

\section{A Transformational Century}

In 1903, the church came under the direction of a new pope, Pius X (1835-1914, r.1903-14). Considerable evidence suggested Pius's allegiance to the conservative vision of Catholicism. He placed works considered modernist on the Index in 1903. In 1907, the Holy Office condemned sixty-five propositions it deemed modernist. In September of the same year, Pius issued the encyclical Pascendi dominici gregis, condemning modernism and "evolutionary" principles, or principles that promoted change in Catholic doctrine. In 1910, Pascendi resulted in the creation of a compulsory anti-modernist oath to be taken by Catholic clergy and teachers. Yet in one regard, that which seemed inflexiblewhich had in fact proclaimed itself to be inflexible-proved willing to adapt. Since the establishment of the Kingdom of Italy, Italian Catholics had been instructed not to participate in Italian politics, given the church's claim that the nation stood on illegitimate and anti-Catholic foundations. Pius did not overturn the Non expedit, but he made it known that Catholics' participation in Italian politics was now welcome, as long as its goal was to break the impasse between church and state on terms that preserved the church's dignity and spiritual authority.

The Civiltà supported this new political approach as it had supported the old. Rather than marking a loosening of its insistence on doctrinal orthodoxy, the Civiltà's political moderation was accompanied by the journal's continued, or even increased, opposition to anything it deemed modernist. But something surprising happened. It turned out that the Civiltà could not prove its orthodoxy to the group of ultra-conservative Catholics who insisted that all social and political action must emerge from fealty to the Catholic Church, and who came to be known as integralists. ${ }^{148}$ Jesuits associated with the journal came to see that cooperation with anti-modernist Catholics could never be sufficiently exact and sweeping to satisfy the integralists, and that their efforts at

147 Ciani, "Across a Wide Ocean," 246.

148 Ciani, “Across a Wide Ocean," 332. 
cooperation limited the journal's influence among all other Catholics. It was again time to adapt.

From about 1908 forward, the Civiltà distanced itself from forms of Catholicism that deplored democracy, and it began to gentle its tone. When Benedict XV (1854-1922, r.1914-22) became pope, he affirmed the possibility of civil disagreement among faithful Catholics; the Civiltà supported his stance. The journal also advocated acceptance of Catholic laborers' participation in mixed-faith trade unions. In 1915, Włodzimierz Ledóchowski (1866-1942, in office 1915-42) became the twenty-sixth superior general and made clear that he would not ally the Society with hard-liners; moreover, he would defend it from their attacks. There had long been Jesuits who declined to participate in the Civiltà's once-aggressive rejection of change: the Austrian Josef Andreas Jungmann (1889-1975), for example, had demonstrated that Catholic practices of confession and the Mass itself had evolved over the centuries, and some Spanish Jesuits had not only revived attention to Ignatius's mysticism but also explored the Society's own capacity for adaptation. Now, the Society as a whole began a gradual, notable evolution in thinking.

In the United States itself, there had been signs since at least the late 188os that some influential Jesuits were beginning to advocate careful accommodation to modern developments in the realm of education. True, some Jesuits seemed to want to protect their institutions from change and criticism, attributing families' decisions to send children to secular colleges as products of pride and disloyalty, and seeming to long for some kind of ban on Catholic families sending their children to secular colleges. But others turned their gaze on Catholic institutions' shortcomings. Internal critics of Catholic education were decrying Catholic colleges' continued mixing of ages and their failure to set intellectual standards, the latter stemming both from the need to attract and keep tuition-paying families, and from the lack of intellectually ambitious faculty. Compounding the worries about standards was the growing conviction that strict supervision of collegians would inspire revolt or simple refusal to enroll (and in fact, students at Jesuit Loyola College in Baltimore threatened to leave entirely unless they were no longer herded along to classes with the younger boys). If Catholics were to receive good secondary education - and to receive them at Catholic rather than secular schools-perhaps some changes were needed. ${ }^{149}$

During this era, and inspired in part by competition with Catholic University, Georgetown's president, Joseph Havens Richards (1851-1923), sought to reinvigorate his institution. He intended to turn it into a model university, with

149 Gleason, Contending with Modernity, 22-27. 
renowned research faculty, modern undergraduate curricula, and ambitious graduate training, including in the sciences. Results were mixed, but Richards made clear that Georgetown meant to stake its claim as the center of American Catholic intellectual life. Richards also tried to engineer the move of Woodstock to Georgetown. Other Jesuits were arguing for its incorporation into Fordham, and this interest in bringing Woodstock to a city signaled an important break, on the part of those who possessed it, with the Jesuits' long-standing view that novices should be protected from the wider world. In the end, though, Woodstock remained in Maryland. None of the era's Jesuit superior generals could perceive, amid the rivalries between provinces and between the Jesuits and secular clergy, an uncontroversial way to move it. So Woodstock College continued to offer a Thomistic education and a secluded setting in which to train and protect young men. And although some Jesuits harbored ambitions that institutions such as Fordham and Georgetown become leading institutions of American higher education, Jesuits throughout the extensive system of colleges and universities still did not embrace an understanding of the university — or of themselves — as producers of new knowledge. ${ }^{150}$

There was one realm in which Jesuit scholarship paved new ground during this era, and that was the field of history. As the twentieth century began, Thomas Hughes, S.J. (1849-1939) published a multi-volume History of the Society of Jesus in North America. His narrative detailed the arrival of Jesuits in the colonies through the Society's suppression, and his collected documents included sources from the early seventeenth century through 1838 , reproduced in their original languages and copiously annotated. Gilbert J. Garraghan, S.J. (1871-1942) produced a detailed three-volume narrative history of Midwestern Jesuits during decades he rightly deems "crowded with every sort of ministerial and educational activity."151

Such histories tended to offer an argument, implicit or explicit, that good Catholics could also be good Americans, the same argument Carroll had made in the earliest days of American independence. By the turn of the twentieth century, many in the United States agreed. President Theodore Roosevelt (1858-1919, in office 1901-9) gave the commencement address at Georgetown College, and in 1909, President William Howard Taft (1857-1930, in office 190913) gave a speech praising American clergy, shaking hands with priests as he was photographed for a story in the Washington Post. By 1911, Edward White (1845-1921), a Catholic alumnus of Georgetown College, served as chief justice

150 Schroth, American Jesuits, 108-9.

151 Garraghan, Jesuits of the Middle United States, 1:v. 
of the Supreme Court. More and more, the United States seemed a place where Catholicism flourished.

It was also a nation undergoing rapid and profound change. Immigrants from Europe entered the country in large numbers, their origins (Southeastern and Eastern Europe) worrying native-born Americans, including some whose own parents or grandparents had been mistrusted immigrants. Industrialization widened the gulf between rich and poor, and workers organized in an effort to ameliorate the power of ascendant capitalists. Socialism and communism gained adherents on both sides of the Atlantic, and in the United States, the Social Gospel movement sought to create a just economic and political order within the framework of liberal Protestantism. Now several decades removed from enslavement, African Americans faced harrowing discrimination in the South and would soon begin the Great Migration north and west, where extraordinary challenges remained. Jesuits in the United States-who were themselves increasingly native-born-held varying views about where duty and justice lay in this changing world. The twentieth century would find Jesuits enmeshed in the economic and social controversies that characterized the nation as a whole.

In 1909, Jesuits in the United States created a forum, the journal America, meant to connect to the world as assertively as Woodstock College had remained separate from it. America was intended to offer a Jesuit perspective on the times and to become "a bond of union among Catholics and a factor in civic and social life."152 The journal covered events throughout the world, offered observations about New York, the city in which it was located, and displayed, in historian Raymond Schroth's words, "a steady respect for authority, especially the hierarchy."153 The periodical turned a critical eye on child labor and the factory system. It argued for racially integrated workplaces, while insisting that it did not request integration "in the social or profane sense." 154 It took an interest in educational reforms and, as the First World War began, cautioned against the Wilson administration's pro-British stance.

America's wariness toward the First World War was not the dominant position within the American church; on the contrary, the war found Catholic prelates determined to demonstrate loyalty to the national cause. Cardinal Gibbons endorsed the need for military preparedness, and American archbishops informed President Woodrow Wilson (1856-1924, in office 1913-21),

\footnotetext{
152 Quoted in Schroth, American Jesuits, 116.

153 Schroth, American Jesuits, 116.

154 Charles R. Morris, "The First Fifty Years: The Emergence of a Catholic Voice," America (April 13, 2009).
} 
"We are all true Americans ready as our age, our ability, and our conditions will permit, to do whatsoever is in us to do, for the preservation, the progress and the triumph of our beloved country."155 Jesuits soon signed on: thirty-nine American Jesuits were commissioned as chaplains. Jesuit universities participated in the War Department's short-lived but ambitious Student Army Training Corps (SATC), which was established in 1918 and intended to train students for soldiering as they continued with their courses. Two Jesuits, historian Peter Guilday (1884-1947) and the future founder of Georgetown's School of Foreign Service, Edmund Walsh (1885-1956), served as administrators in SATC's bureaucracy. ${ }^{156}$

After the war, the church in the United States became increasingly confident and centralized, with national organizations such as the National Catholic Welfare Conference and the National Catholic Rural Life Conference drawing together what had once been only loosely associated dioceses. The Catholic Educational Association was a charter member of the Emergency Council on Education, which began during the First World War and became an important voice and arbiter of American higher education. ${ }^{157}$ Catholic scholars of the era founded organizations including the American Catholic Historical Association (1919) and the Catholic Anthropological Conference (1926), while Francis X. Talbot, S.J. (1889-1953) inspired the Catholic Book Club, the Catholic Poetry Society, and the Catholic Theatre Conference. ${ }^{158}$ Catholic laypeople also created organizations, such as the National Councils of Catholic Men and Women. This lay leadership accorded with developments in Europe, such as Pope Pius XI's (1857-1939, r.1922-39) 1931 definition of Catholic Action as "the participation of the laity in the apostolate of the hierarchy."159

The response to Al Smith's (1873-1944) 1928 presidential campaign demonstrated that old prejudices could still be sharpened into political weapons. But some Protestants and Jews, as well as those without religious affiliation, were appalled by the open anti-Catholicism of the campaign against Smith. Catholic leaders favored advance over retreat. Some pursued the creation of The Catholic Hour, a radio program on NBC that led to the emergence of Bishop

\footnotetext{
155 Quoted in James Hennessey, American Catholics: A History of the Roman Catholic Community in the United States (New York: Oxford University Press, 1983), 225.

156 Gleason, Contending with Modernity, 24-25.

157 Gleason, Contending with Modernity, 71-72.

158 Gleason, Contending with Modernity, 150-51.

159 Quoted in Jeremy Bonner, Mary Beth Fraser Connolly, and Christopher Denny, "Introduction," in Empowering the People of God: Catholic Action before and after Vatican II, ed. Jeremy Bonner, Mary Beth Fraser Connolly, and Christopher Denny (New York: Fordham University Press, 2014), 1-17, here 3.
} 
Fulton J. Sheen (1895-1979) as a Catholic guide and celebrity. ${ }^{160}$ Proclaiming a "Catholic Revival," Catholic intellectuals, Jesuits among them, celebrated works of literature by authors including G. K. Chesterton (1874-1936), Hilaire Belloc (1870-1953), and Christopher Dawson (1889-1970), promoting and analyzing them in public lectures and books as well as in college courses.

\section{$23 \quad$ Toward Modernity}

Jesuits had long been skeptical of modern nationalism. But across the course of the nineteenth century, American Jesuits had knit their purposes into the nation's sense of mission, and as the twentieth century dawned, members of the Society began to participate willingly in American imperialism. An important moment came when the superior general replaced Spanish Jesuits in the Philippines with American ones. The distance between Jesuit purposes and national aims - so evident in the polyglot Rocky Mountain mission, for example-faded in this endeavor, and so did the mistrust of national pride that had long characterized the Jesuit ethos. Fully committed to their primary role as Catholic missionaries, American Jesuits also introduced American styles of dress and sports such as boxing. ${ }^{161}$

American Jesuits' education mission was expanding during these decades. Between 1880 and 1954, the number of students enrolled in Jesuit high schools, colleges, and universities swelled from under five thousand to over 120,000. American Jesuits had begun to teach students in other countries, as part of missions, and that added another ten thousand students to the total under their tutelage. Thousands studied in Jesuit law schools alone, and five Jesuit universities developed medical schools. Responding to Ledóchowski's call that deans stop hiring non-Catholics as professors, Jesuit universities set out to train faithful PhDs who could staff these growing institutions. ${ }^{162}$

American Jesuits slowly - very slowly_began to adapt schools to the demands of American parents, children, and accreditation boards. Jesuits separated younger boys from those participating in what were coming to be understood as distinct colleges. Some warmed to the possibility of a "commercial course" meant to appeal to students and parents eager for a more practical education. (It was not always a smooth process; at Fordham, one president began a commercial course, a second abolished it, and a third brought it back.)

160 Gleason, Contending with Modernity, 146-47.

161 McGreevy, American Jesuits, chapter 6 (179-209).

162 Schroth, American Jesuits, 175 . 
In 1915, Jesuit colleges began teaching philosophy in English rather than in Latin, and in the early 1920s they introduced majors and adopted a system of credit hours. Such adjustments were meant to honor Catholic families' desire for upward mobility, and they may have been influenced by the creative adaptations teaching sisters had introduced with less reluctance.

These changes in Jesuit education, significant though they were, occurred amid a general strategic torpor. Evidence comes from the order's own analysis. In 1931-32, the American Society of Jesus commissioned what came to be known as the Macelwane report, which lambasted the facilities and ethos of Jesuit higher education in the United States. James B. Macelwane (1883-1956) was a physicist at St. Louis University; the report he masterminded specifically criticized Jesuit institutions' poor libraries, their lack of rigorous, specialized upper division courses and professors trained to teach them, and their reliance on poorly trained administrators. It urged that the Society only accept men as novices after they had two years of training and observed that scholasticates should collaborate with university graduate programs, so that throughout their formation, young Jesuits understood themselves as scholars in training. The report also offered a broader commentary as its authors warned that the same ethos that caused these problems meant the report itself was unlikely to change them. "The inertia of local traditions," the text reads, "the inbred opposition of Ours to any change, and the prevailing ignorance of conditions among both inferiors and superiors, all call for energetic action, which can only come from a head exercising inter-province power."163

The commission the Macelwane report urged was not created. Novices continued to enter immediately following high school, and theologates including Woodstock maintained their proud distance from universities; as late as 1957, a new theologate was opened not near Fordham, as a number of Jesuits had proposed, but rather at Shrub Oak, in rural Westchester County. American institutions of higher education had begun to form organizations in an effort to raise standards, and Jesuit colleges and universities more than once found themselves on the wrong side of the organizations' judgments. When in 1934 the American Council on Education published a list of sixty-six approved doctoral programs, no programs at Jesuit institutions were included. The next year, Fordham lost accreditation from the Association of American Universities for its graduate school and its oldest college. Despite the MacElwane report's sounding of the alarm, decades would pass before Jesuit institutions significantly reformed their facilities, admission of novices, and scholarly standards in the way the report counseled.

163 Schroth, American Jesuits, $181-83$, quote at 181 . 
That Jesuit colleges and universities were single-sex had also slowly begun to distinguish them from other institutions. Oberlin College was founded as a coeducational institution in 1833, and other small religious colleges followed its example. Midwestern land grant institutions began to admit women in the second half of the nineteenth century, and by 19oo, around seventy percent of American colleges and universities were coeducational, with forty percent of American college students being women. Within Catholic higher education, the founding of Catholic women's colleges, rather than coeducation, was seen as the answer to the desire for Catholic women to attend college. The gendered architecture of the Catholic Church provided the answer; women religious were fully capable of founding and staffing these institutions, and by midcentury there were over one hundred Catholic women's colleges. Nonetheless, the coeducational model slowly gained ground. Loyola University Chicago, Xavier University, Fordham, and Canisius College enrolled women during the First World War, and St. Louis University admitted women to its law school in 1908. Yet, there was still significant opposition, including from Ledóchowski, who in 1928 condemned coeducation in all Jesuit schools. ${ }^{164}$

Founding and staffing American schools remained the central occupation of Jesuits in the United States, but it was not the only one. American Jesuits were now sent on missions overseas, no longer themselves part of a mission territory. The turn had begun in the late nineteenth century, and soon, Jesuits from New York ministered in the Philippines, Micronesia, Nigeria, and Ghana. Jesuits from New England served in Jamaica and Jordan, and in 1932 were commanded by the pope to create a high school in Baghdad. California Jesuits were sent to China, Jesuits from New Orleans to Ceylon (Sri Lanka), and others served in India, British Honduras, and Chile.

Some Jesuits argued for the need to serve the United States itself in ways that went beyond offering traditional education to children and young adults. A few had begun to offer retreats for laypeople in the late nineteenth century, reasoning that the gifts of the Spiritual Exercises should, in some form, be shared beyond the Society. The Jesuit Retreat Center in Parma, Ohio, dates its first lay retreat to 1898 , when a Jesuit novice master invited fourteen laymen to the house (two came). In 19o9, Terence J. Shealy, S.J. (1863-1922), then a lecturer at Fordham Law School, involved New York's Archbishop John Farley (1842-1918) in a plan to offer lay retreats on a more ambitious scale; Mount Manresa, in Staten Island, hosted its first retreat in 1911. By mid-century, Jesuit

164 Susan L. Poulson and Loretta Pierfedeici Higgins, "Gender, Coeducation, and the Transformation of Catholic Identity in American Catholic Higher Education," Catholic Historical Review 89, no. 3 (2003): 489-510, here 490-93. 
retreat houses had been created throughout the United States-a number named after Manresa, Spain, where Ignatius of Loyola wrote the nucleus of his Spiritual Exercises.

Other Jesuits sought to work directly for the country's many vulnerable inhabitants. One Boston Jesuit opposed the founding of Boston College, convinced that what was needed was not another educational institution but rather direct service to the poor. He was the exception in explicitly questioning the Society's focus, but other Jesuits contemplated the challenges posed by industrial capitalism, continuing a line of thought evident since the 1870 and expressed in Rerum novarum. ${ }^{165}$ Three Jesuits teaching at a high school in New York City decided to preach on weekends to inhabitants of Hell's Kitchen. (Like many Protestant reformers, the Jesuits were unsettled by what they saw as disordered, defiant immigrant families.) Jesuits also visited inmates in prisons and the sick in hospitals, venturing into labor that women religious had been carrying out in cities for generations. Jesuits engaging in what might be called a social apostolate sought to ameliorate capitalism's most brutal consequences and to make it accord with Catholic social teachings. Scholar Peter McDonough notes that "the material circumstances in which immigrant Catholics lived and the class origins of many Jesuits encouraged support for welfare programs and distributive policies at the same time that their ethnic and religious identification curbed the appeal of radical options."166

Sympathy for workers was accompanied by hostility toward the political theory some embraced: communism. In fact, Jesuits participated in the efforts of labor unions to purge their ranks of communist influence. America shared this ethos, exploring the brutalities of American factories while warning against communist influence in labor unions at home and worldwide. ${ }^{167}$ This approach accorded with that of labor organizations such as the American Federation of Labor, which also sought to offer workers dignity within capitalism, rather than positing a competing system. Catholics outside the Society also held such a view. Inspired by the 1891 encyclical Rerum novarum as well as by his childhood experience of deprivation, John A. Ryan (1869-1945), not himself a Jesuit, developed proposals to protect the dignity of individuals within an industrializing, capitalist nation. Ryan advocated a minimum wage, an eighthour day, and public ownership of utilities and national resources, while also arguing that private land ownership was an individual right. When he became

\footnotetext{
165 McGreevy, American Jesuits, 168-71.

166 Peter McDonough, Men Astutely Trained: A History of the Jesuits in the American Century (New York: Simon \& Schuster, 2008), 95.

167 Morris, "First Fifty Years."
} 
director of the Social Action Department - part of the National Catholic War Council-Ryan continued to argue for industries' responsibilities to workers and publicized the perils of child labor. ${ }^{168}$

A Wisconsin-born Jesuit on the staff of America, Joseph Husslein (18731952), was similarly inspired by Rerum novarum. In a series of articles for America, Husslein offered a view of the pre-capitalist world as communal and relatively egalitarian and tried to offer a revived communalism that might thrive in an industrial world and specifically in the immigrant-rich, economically unequal United States. Husslein also created a long-running series of publications, which he called "A University in Print," designed to offer a Catholic worldview-aculture, in theincreasingly popularterm of the day-toreaders. ${ }^{169}$

It was a Jesuit whose gaze was turned to foreign affairs more than domestic inequality, however, who most dramatically influenced the US response to socialism and communism. In 1919, Walsh — who had been a priest for only three years-founded the Georgetown School of Foreign Service, the nation's first school for diplomats. Walsh intended that the school create "a trained body of men bred in a spirit of devotion to the institutions and idealism of the United States," a fascinating sublimation of the Jesuit mission itself. In 1922, Walsh was named director of the papal relief mission in Soviet Russia, then experiencing devastating famine. Witnessing starvation, the imprisonment and execution of clergy, and the sacking of churches, Walsh came to see Soviet rule as a successor to the French Revolution's assault on the church. He was horrified at what he saw as its "concomitants-no state, no government, no belief in God, no marriages, no religion or in a word, the total destruction of the present Christian civilization and the substitution of the Communistic state." For the next several decades, Walsh's message to both the American public and policymakers would be that there could be no productive diplomatic relations with the Soviet Union and that the UsSR's assault on religion threatened the entire world. ${ }^{170}$

168 Karl H. Cerny, "Monsignor John A. Ryan and the Social Action Department" (PhD diss., Yale University, 1955); Joseph McShane, "Sufficiently Radical": Catholicism, Progressivism, and the Bishops' Program of 1919 (Washington, DC: Catholic University of America Press, 1986).

169 Gleason, Contending with Modernity, 149.

170 Patrick J. McNamara, "The argument of strength justly and righteously employed': Edmund A. Walsh, Catholic Anticommunism, and American Foreign Policy, 1945-52," U.S. Catholic Historian 2, no. 4 (2004): 58-62, quotes at 59, 61; Marisa P. Trythall, "Russia's misfortune offers humanitarians a splendid opportunity': Jesuits, Communism, and the Russian Famine," Journal of Jesuit Studies 5, no. 1 (2018): 71-96. 
The Crash of 1929 and subsequent global economic collapse made capitalism — and it seemed to many, social order itself - more vulnerable than ever before. Dorothy Day (1897-1980) and Peter Maurin (1877-1949) founded the Catholic Worker Movement in an effort to meet the immediate needs of people suffering from the Depression and to create communities in which people might be empowered, even in difficult circumstances, to be good. "The biggest challenge of the day is: how to bring about a revolution of the heart," Day wrote. Perhaps the nation's best-known Catholic priest, Charles Coughlin (1891-1979), took a different path. Coughlin cultivated a large radio audience; after initially urging his listeners to support FDR's New Deal, he unsuccessfully attempted to found his own political movement, one in which Roosevelt and "Bolshevik" union leaders appeared as enemies, and workers were threatened by elites and, in Coughlin's increasingly brutal language, by Jews. Coughlin's vulgarity may have differentiated himself from American Jesuits, but his hostility to communism and arguably his underlying anti-Semitism did not. Coughlin established relationships with editors of America, and even when the priest fell from favor, the journal never castigated his anti-Semitism. On the contrary, America protested the eventual censoring of Coughlin on grounds that a powerful minority, clearly meant to be read as Jews, had achieved his silencing. ${ }^{171}$

The Depression alarmed Jesuits not only because of the immense suffering it created but also because it seemed likely to provoke struggling people to turn to communism for aid. In 1934, Ledóchowski issued "On the Need of Vigorously Opposing Modern Atheism," in which he called on Jesuits to combat the linked advances of communism and atheism. In the United States, Jesuits uneasy at the communist challenge developed two basic theories of how to proceed. The first came from John LaFarge (1880-1963). In his fifties during the Depression, LaFarge as a young man had been judged by his Jesuit superiors too frail to be a scholar and was put into parish work. In New York, he ministered to people in hospitals, prisons, and the city's workhouse; sent next to Maryland, he met the descendants of people enslaved by Jesuits, for whom the era of bondage felt like a personal memory. ${ }^{172}$ LaFarge was made an assistant editor of America Magazine in the 1920s, and he worked there in various capacities for the next thirty-six years. Convinced that communism would destroy the earthly and spiritual prospects of any whom it attracted, LaFarge developed a strategy for combating it as aggressively as possible. He drew on the martial ethos the

\footnotetext{
171 Charles Gallagher, “'Correct and Christian': American Jesuit Support of Father Charles Coughlin's Anti-Semitism, 1935-38," in Bernauer and Maryks, "Tragic Couple," 295-315.

172 Schroth, American Jesuits, 118-20.
} 
Society had often cultivated in the past, calling for aggressive, multifocal opposition to communists and communist arguments wherever they emerged. At a 1935 meeting of the Missouri-Chicago province, LaFarge proposed a "United Front" that would disparage communist claims to create a benevolent global popular initiative against fascism and "gain control of worthy causes, such as [the] peace [movement], Labor, Adult Education, [and] cooperative movements." Jesuits were to counter intellectual, artistic, social, and political forays of communists with their own efforts, and they would also use the colleges as sites to enlist young men in the battle against communism, the spiritual foe against whom the Jesuits now marshaled. ${ }^{173}$

There was a second theory of Jesuit anti-communism, more centralized than local, and more focused on creating a Catholic vision than on countering communist claims. This, rather than LaFarge's vision, captured the Society's imagination-and Walsh's. Walsh shared LaFarge's goal of turning Americans firmly against communism, but he disapproved of LaFarge's United Front, unwilling to have the Jesuits appear as direct political actors and eager that the Society not become associated in the public mind with Father Coughlin, whose fascism and anti-Semitism offended him. What was needed, Walsh felt, was a positive alternative to communism. An effective proponent of his approach was a Chicago-born Jesuit named Daniel Lord (1888-1955). Lord was a tireless cultural impresario who had turned the fading sodality of Our Lady into a thriving network of charitable and devotional groups, with a magazine, The Queen's Work, that Lord himself edited. (He also wrote pamphlets and music, produced musical pageants, and was during the Depression involved in drafting Hollywood's production code.) Lord's "Plan of Action for the Establishment of a Christian Social Order" articulated a positive Catholic vision meant to render Americans permanently immune to communism's charms. Lord's Establishment of a Christian Social Order was shortened to Ecso and then $\mathrm{XO}$, the term widely used to describe Jesuit social action. ${ }^{174}$

The second model of Jesuit anti-communism found implicit endorsement in Pius XI's 1937 encyclical Divini redemptoris, which advocated an emphasis on justice, the dignity of the human person, and the relief of poverty in the fight against communism. The next year, Ledóchowski announced that he favored an American version of the French Action Populaire system, which

173 Charles R. Gallagher, "Decentering American Jesuit Anti-communism: John LaFarge's United Front Strategy, 1934-39," Journal of Jesuit Studies 5, no. 1 (2018): 97-121, here 103-7, quote at 107.

174 Gallagher, "Decentering American Jesuit Anti-communism," 11. 
created forums for conversation on social issues. LaFarge doubted the wisdom of a transplanted European model — not the first Jesuit to argue that North America required distinctive adaptations - but Ledóchowski formally ordered the creation of "a social center [...] located in the city of New York [...] for $[\ldots]$ the struggle against Communism." ${ }^{175}$

The result was the Institute of Social Order (ISO), which tried to ameliorate the cruelties of capitalism while forestalling any threat of communism. The Iso was founded in 1947 and intended to combine "social philosophy, propaganda, and action." Its first head, John P. Delaney, S.J. (1906-56), was a charismatic figure whose efforts consisted not of social scientific analysis but of a warm pastoral attention to the working-class families he drew into his orbit. Delaney was removed within a few years, and the Iso's second director, Lord, found it difficult to make the Iso a central, or even a significant, part of the American Jesuits' labor and self-conception. Lord also worried that some forms of social analysis and action might alienate benefactors of other Jesuit projects. Provincials he queried tended to express confidence that church teachings properly understood could not offend good Catholics (even good Catholic businessmen), but Lord's Is o nonetheless struggled to be meaningful. Unlike Day's Catholic Workers, it attracted little interest beyond the Society. In the early 1950s, only ten Jesuits worked for the ISo, and that figure soon declined by half. ${ }^{176}$

During these years, the Jesuits also created schools for social work at Fordham, Loyola, and other universities. Allied with the new business and law schools at Jesuit universities, the labor schools sought to gentle American capitalism and to empower Catholics to make their way within it. Jesuits also founded a small set of "labor schools," which offered participants in cities such as Buffalo, Syracuse, and New York training in unionizing as well as technical courses. Jesuits encouraged workers to find dignity and fulfillment in manual labor, and, in the words of an Iso bulletin, to "bring Catholic doctrines and principles to bear" on union work. Workers were to strive for a Catholic form of contentment rather than indulge in a Protestant or secular desire for advancement. In all these endeavors, Jesuits offered St. Joseph and the apostles

\footnotetext{
175 Quoted in Gallagher, "Decentering American Jesuit Anti-communism," 118. See also Philippe Chenaux, "Father Włodzimierz Ledóchowski (1866-1942): Driving Force behind Papal Anti-communism during the Interwar Period," Journal of Jesuit Studies 5, no. 1 (2018): 54-70.

176 McDonough, Men Astutely Trained, chapter 6 (168-213).
} 
as examples of laborers who did God's work. "Give them over and over again Christ the working man as a real man," Delaney instructed. ${ }^{177}$

Like most things in the United States, capitalism was entwined with race. Jesuits had participated in slavery; now Jesuits participated in Jim Crow. Yet as the Jesuits contemplated the economic order, some questioned their complicity in the nation's racial regime, finding Rome's occasional declarations of the unity of humanity insufficient to the urgency and specificity of the American situation. At the Iso, Delaney's successor, Lord, was also interested in racial justice but cautious. Lord was a charismatic showman who racially integrated the performances he produced. But he was unwilling to offend those who supported the existing racial regime. LaFarge also persistently, if cautiously, questioned whether Jesuits were behaving justly given the nation's racial injustice. Before being assigned to America, he helped to establish the Cardinal Gibbons Institute, a vocational school for African American children located in Maryland, the cradle of the American Catholic Church and of Jesuit slaveholding. When LaFarge was made associate editor of America, he brought his interest in racial injustice with him. It was an earnest but constrained understanding. The Gibbons Institute had been the site of arguments between a deeply well-meaning but paternalistic LaFarge and the school's African American educators and trustees. Now, at America, LaFarge published pieces evincing a mixture of condescension and concern; an article about Harlem's 1936 riots blamed white communist agitators but also analyzed African American economic disenfranchisement. In articles and books, LaFarge argued that African Americans could and must find in Catholicism remedies for the spiritual and social suffering LaFarge diagnosed. Scholar David W. Southern has noted both the "limits" of LaFarge's engagement and imagination and his determination to create an "interracial" Catholicism. ${ }^{178}$

Limited though it was, Lord's and LaFarge's discontent with the US racial regime distinguished them from many, and perhaps most, of their brethren. A few universities in the West admitted students of color, but for the most part, Jesuit institutions - theologates, schools, and colleges—remained segregated because American schools and colleges for the most part remained segregated. As with slave ownership in the preceding centuries, Jesuits in this regard adapted to American culture all too well.

177 McDonough, Men Astutely Trained, chapter 9 (277-94); Joseph M. McShane, “'The church is not for the cells and the caves': The Working-Class Spirituality of the Jesuit Labor Priests," U.S. Catholic Historian 9, no. 3 (1990): 289-92, quotes at 290, 292.

178 David W. Southern, John LaFarge and the Limits of Catholic Interracialism, 1911-1963 (Baton Rouge, LA: Louisiana State University Press, 1996). 
The cataclysm of the Second World War left little in the world untouched, including the Society of Jesus. Around twenty million combatants and fortyfive million civilians died. Although Pope Pius XII (1876-1958, r.1939-58) had helped to draft a 1937 encyclical condemning Nazism, the Vatican adopted a policy of neutrality during the Second World War. Pius sought to use diplomacy and to encourage clergy, women religious, and laity to quietly ameliorate suffering and protect victims of the Holocaust. Many scholars and survivors have deplored the church's failure to directly combat or, during the war, even to directly condemn, Nazism. In 2012, the World Holocaust Remembrance Center (Yad Vashem), located in Jerusalem, softened its criticism of Pius XII, recognizing evidence of his efforts to aid Jews. Yet even there, the record is painful; after the war, the pope issued a directive- - which did not mention the Holocaustinstructing Catholics who had harbored Jewish children to drag their feet in response to inquiries from Jewish organizations searching for sheltered children, and to avoid returning baptized children to Jewish caretakers.

Some members of the Society of Jesus more assertively opposed Nazism than Rome did. Forty-three Jesuits died in concentration camps, the majority in the priest barracks at Dachau, and the German provincial general was sentenced to death for his role in a plot on Hitler's life. Yet Jesuits' earlier complicity in Europe's anti-Semitism is undeniable, and in the years immediately preceding the Second World War, Jesuits, not least the superior general, failed to distance themselves from the profound anti-Semitism of the fascist states. When Pius XI asked LaFarge to draft an encyclical opposing racism, anti-Semitism, and fascism together, the request alarmed the Jesuit superior general, Ledóchowski, who feared that Joseph Stalin (1878-1953) might benefit from a papal broadside against Hitler. LaFarge delivered his draft, which he wrote with a fellow priest, to the cautious Ledóchowski, and the document seems not to have reached Pius XI before his 1939 death; scholarly opinions differ as to whether the document might have made a difference, if it had. ${ }^{179}$

The United States' 418,00o casualties were a small part of the war's grotesque total, yet devastating, nonetheless. As in previous wars, American Catholics served in the military and supported the war effort, their determination to

179 Frank J. Coppa, "The Hidden Encyclical of Pius XI against Racism and Anti-Semitism Uncovered: Once Again!," Catholic Historical Review 84, no. 1 (1998): 63-72; Ernest Greco, "Popes, Catholics, and Jews: È questa la maniera di fare storia?," in Catholicism and Historical Narrative: A Catholic Engagement with Historical Scholarship, ed. Kevin Schmiesing (New York: Rowman \& Littlefield, 2014), 189-206. 
fulfill their duty perhaps augmented by a desire to prove, once again, that Catholics were good Americans. By 1945, 246 American Jesuits were serving as chaplains, over one hundred from the New England and New York provinces alone. ${ }^{180}$ The war also caused young men to leave Jesuit universities for the service. Fordham saw its enrollment decline by twenty percent in 1942; two years later, it had only one-third the number of students it had before Pearl Harbor. At the University of Santa Clara, enrollments dropped from 697 in September of 1940 to ninety-one in January of $1943 .{ }^{181}$ Male students who remained at Jesuit institutions were often involved in military training; institutions including Georgetown were selected by the War Department to house Army Specialized Training Programs, and in the face of shrinking tuition revenues, government contracts to train military personnel were valued even by institutions that had recently questioned the wisdom of accepting federal funds. ${ }^{182}$ Jesuit faculty were among those who became chaplains; Martin J. O'Gara, S.J. (d.1946) had taught in Georgetown's religion department before serving as a chaplain; he died in a military plane crash not long after the war's end.

Walsh had since his earliest years as a Jesuit seen communism as the greatest threat to mankind. He agreed that the prime directive during the war was to defeat fascism, yet he remained vigilant against what he considered unnecessary collaboration with or sympathy for the Soviet Union. The Second World War in fact drew one Jesuit into the Soviet Gulag itself, though no one realized it until years later. Walter Ciszek (1904-84) was the American-born child of Polish immigrants. Early in his formation, Ciszek learned that Pope Pius XI was establishing a center in Rome designed to train priests for work in the Soviet Union. Ordained in 1938 after studying Eastern Orthodox Christianity, Ciszek was sent to Poland because of Russia's refusal to accept priests. In 1939, he slipped into Russia, where he was eventually arrested as a spy and sent to the Gulag. Ciszek survived and clandestinely worked as a priest. "I was able to say Mass [...] although in secret," he later wrote, "to hear confessions to baptize, to comfort the sick, and to minister to the dying." ${ }^{183}$ His family and brethren thought he had died, but in 1963, a letter from Ciszek reached home; shortly

\footnotetext{
180 Joseph P. Duffy, "To Love and Serve: World War II Chaplains of the New England Province of Jesuits," New England Province History 5 (2014): 1-94, here 6.

181 Thomas J. Shelley, Fordham: A History of the Jesuit University of New York; 1841-2003 (New York: Fordham University Press, 2016), 311; William P. Leahy, S.J., Adapting to America: Catholics, Jesuits, and Higher Education in the Twentieth Century (Washington, DC: Georgetown University Press, 1991), 131.

182 Leahy, Adapting to America, 133.

183 "Jesuit Father Walter Ciszek: A Life in Service"; https://jesuits.org/news-detail?TN=NEWS -20171013024940 (accessed November 7, 2019).
} 
before President John F. Kennedy's (1917-63, in office 1961-63) assassination, the Jesuit's release from the Soviet Union was negotiated and he returned to the United States. He lived for another twenty years, serving as a counselor, lecturer, and spiritual director at Fordham University and authoring two books.

Ciszek returned to a dramatically changed country. After the war, Catholics, like other Americans, took advantage of a growing economy and the Servicemen's Readjustment Act of 1944, popularly known as the GI Bill, which provided education and housing benefits to returning servicemen, in order to advance themselves; many left ethnic enclaves for suburbia. Catholics had now fought with their fellow Americans in two world wars and they held prominent positions in the public and private sector. The anti-Catholicism that had flared at other points in American history - most recently during the Ku Klux Klan violence following the First World War and in the opposition to Al Smith's 1928 presidential campaign - had ebbed. Immigration restrictions put in place in the 1920 meant that fewer Catholics than in the recent past were immigrants or the children of immigrants, a fact that contributed to the decline in antiCatholic prejudice and also heightened Catholics' confident insistence that there was no tension between being Catholic and being American. That insistence found new support in academic histories. Freshly minted PhDs working under the supervision of famed Catholic historian John Tracy Ellis (1905-92) explored the Americanist controversy of decades earlier and, Gleason has argued, supplied "mid-century Catholic liberalism" with "historical precedent," albeit perhaps without consciously seeking to do so. ${ }^{184}$

An astute observer might have noted signs of unsettling transformations to come. As Catholics grew in confidence and wealth, families became less likely to send their children to Catholic primary and secondary education. Ambitious Catholic adolescents increasingly set their sights on non-Catholic colleges and universities. In cities, once-thriving parishes began slowly to shrink as parishioners moved to suburbs. Catholic colleges themselves also saw an important shift: in the 196os and '7os, changing mores as well as practical considerations encouraged broader inclusion of women in universities' programs. After the Second World War, more Catholic men's colleges had begun to admit women, but tended to keep them physically separated from male students and enrolled in programs outside the colleges of arts and sciences. Now, leaders of Boston College and of Georgetown observed that expanding the pool of applicants to include women would help meet the costs of running ambitious educational institutions, both by bringing in a new category of qualified students and by making the institutions more attractive to qualified male applicants. By 1971,

184 Gleason, Contending with Modernity, 284-85. 
Holy Cross was the only Jesuit post-secondary institution that still did not admit women, and it began to do so that year. ${ }^{185}$

Still, few if any observers would have predicted the extent of the changes to come. In the early 196os, American Jesuits were the Society's largest national group, comprising eight thousand of the thirty-six thousand Jesuits worldwide. Most American Jesuits remained absorbed in the Society's teaching mission, confident that "Ours" — as Jesuits often called the community — could thrive just as they had been doing. The church seemed no more poised for dramatic change than the Society: after the war, Pope Pius XII had issued Humani generis, cautioning against "errors, false opinions, and dangerous tendencies of our day" and had canonized Pius $\mathrm{x}$, foe to modernism.

Within Jesuit seminaries, life continued to be marked by the major holy days and the commemorations of Jesuit saints, and the ringing of bells to divide the day into a cycle of prayer, study, exercise, recreation, and meals. Young men were in the novitiate for two years, then took vows, adding "S.J." to their names and the characteristic square black hat, the biretta, to their wardrobes. Supervision and constraint were important to Jesuit formation: Patrick Howell recalls that as a Jesuit scholastic in the early 196os, he was rarely allowed to travel to see family. ${ }^{186}$ A two-year juniorate found young men reading Greek and Latin texts, after which came three years study of philosophy, usually in a place separate from the novitiates. The seventh year brought regency, which took the men out of the countryside and in most cases into high schools. Four years' study at one of the Jesuit theologates followed; after the third, the man was ordained a priest and said his first Mass. All that remained was a final year of theology and then a year known as tertianship, during which the Jesuit carried out the Spiritual Exercises over a period of thirty days. Then the long period of formation came to an end.

"Jesuits [...] moved in groups," McDonough writes, and they expected change to come gently and incrementally, if it came at all. Formation was characterized by large numbers and considerable rigidity: "The repetitious tempo of a shared life girded religious commitment through habituation and collective movement." It was a setting that allowed small quirks or mannerisms to take on great importance. Francis Edward Peters, author of Ours, recalls a ferocious competitiveness - in sports, in academics, in obedience-among the young men as well as the cultivation of a detachment that could produce a pleasing cosmopolitanism but that, in his case at least, also allowed for disengagement

185 Poulson and Higgins, "Gender, Coeducation," 494.

186 Patrick J. Howell, Great Risks Had to Be Taken: The Jesuit Response to the Second Vatican Council, 1958-2018 (n.p.: Cascade Books, 2019), loc. 620. 
from the devotion meant to lie at the heart of the religious life. Daniel Berrigan (1921-2016), later famous as a protestor of the Vietnam War (1954-75), recalled cold novice masters and marveled at the ignorance of the world that novices enjoyed even as the Second World War approached. Yet Berrigan found spiritual sustenance in his experience that Peters did not. Others did, as well. The novitiate allowed young men "to develop a set of aspirations for service in the church that would grow out of this kind of intimacy with our Lord," one man told an interviewer. "What the noviceship experience was basically about was encountering Jesus," explained another. ${ }^{187}$ Intimacy with the divine and endless, punctilious rules; the period of formation offered all participants the second and some - the first.

Change was more evident at Jesuit colleges and universities. The G.I. bill expanded the possibility of college for a generation of American men, and a profusion of federal programs, including the College Housing Act, the National Defense Education Act, and the Higher Education Act of 1965 sent money toward public and private colleges and universities. The post-war years found Catholics of just about all ethnicities attending college at a higher rate than other American Christians (except Scandinavian Protestants, who equaled them). ${ }^{188}$ Jesuit educators, along with other Catholic leaders in higher education, expanded freshman classes and created graduate programs, seeking to educate Americans within an atmosphere of faith, to prepare Catholic leaders, and to raise the standing of Catholic educational institutions. As they sought success in American higher education, and the federal funding that was necessary to it, Jesuit institutions created lay advisory boards and separated the office of rector from that of president. By 1954, twenty-one of twenty-seven Jesuit institutions of higher learning had created lay advisory boards, and in 1955, John Carroll University chose a non-cleric as vice-president of development, a significant first step toward the creation of lay administrations. ${ }^{189}$

These reforms were part of a concerted effort to improve the quality of Jesuit colleges and universities. Jesuit presidents raised faculty salaries, and at the most elite Jesuit institutions, including Boston College, Fordham, and Georgetown, pay rose to levels comparable with those at prestigious secular institutions. Those institutions gained in stature, as did Notre Dame, fulfilling a long-standing interest in creating visible centers of Catholic intellectual life in the United States. Yet the very proliferation of institutions-a function of the localism that competed with Jesuits' professed cosmopolitanism-also

187 McDonough, Men Astutely Trained, 143-46, quotes at 146, 143.

188 Leahy, Adapting to America, 127.

189 Leahy, Adapting to America, 104-5. 
ensured that many would remain, at least by external standards, mediocre, and that Jesuits would not create select, powerful doctoral programs but rather a profusion of programs in competition with each other. ${ }^{190}$

The post-war period also saw Jesuit colleges and universities grapple with (or refuse to grapple with) America's racial regime. Santa Clara University in California was celebrated in 1908 by an alumnus who recalled that students "were of all ages and nationalities and opposite creeds." The University of San Francisco, a Jesuit institution, admitted African Americans beginning in the ${ }^{1920 s}{ }^{191}$ In much of the rest of the country, however, Jesuit institutions refused to admit African Americans. When progressive Jesuits questioned segregationist policies, they were initially thwarted by brethren who actively favored segregation or simply did not want the Society to risk alienating patrons.

At St. Louis University, a small set of Jesuits argued in the mid-1940s that the university must be integrated. The Second World War had helped to discredit overt racism, both by revealing the horrific consequences of Nazism and by revealing (once again) the essential contributions of African American service people and citizens. Catholic colleges including Notre Dame and its sister school, St. Mary's, began to integrate their student bodies, and in Missouri, the Jesuits' provincial superior, Peter A. Brooks (1893-1948), appointed a committee to contemplate integration at St. Louis University. That committee did not effect change, but the institution's president began tentatively to inquire whether integration would be acceptable to local Catholics and alumni. A St. Louis University faculty member, the Jesuit Claude H. Heithaus (1898-1976), decided that an assertive campaign in favor of integration was needed. Heithaus was an archaeologist and the director of the university's public relations. In 1944, he preached a sermon expressing contrition for past wrongs against African Americans and urging the congregation to avoid repeating them. In a published piece drawn from his remarks, Heithaus stated that African Americans must be welcome at the school. Although it seemed initially that the campaign had succeeded - Life magazine even did a story on the first integrated Catholic university-St. Louis University's administration soon insisted that extracurricular events remain whites only. A protesting Heithaus wrote, in another public essay, that the St. Louis administration's capitulation to the tradition of segregation was like a Christian missionary who, settled among cannibals, began to eat people in order to attract "little cannibal students and big cannibal money." He added, for good measure, that cannibalism was less harmful

190 Leahy, Adapting to America, 103, 139-40.

191 McKevitt, Brokers of Culture, 11, 1, quote at 1; Schroth, American Jesuits, 191. 
than racism, because it only harmed corpses. Heithaus was condemned by his superior and eventually expelled from the university. ${ }^{192}$

Heithaus was not the only Jesuit of the era thwarted in efforts to move the Society into more direct engagement with issues of social justice. George H. Dunne (1906-98) had served in the California Jesuits' mission in China; once back in the United States, he discussed racial segregation, urban poverty, and worker exploitation during Spiritual Exercises he offered to theology students at the California province's theologate. Dunne was chastised by superiors but undaunted. After next being sent to St. Louis University, he supported Heithaus's integration campaign and vigorously condemned segregation. Dunne was removed from the university and sent to California, but still was not silenced; in an article he wrote for the Catholic lay magazine Commonweal, he deemed segregation a sin..$^{193}$

Amid this landscape of institutional inertia and individual courage, there was one unexpected instance of change. Two successive presidents of Spring Hill — the Jesuit college in Alabama that had openly favored the Confederacywere troubled by segregation. In 1949, the college began to include African Americans in some programs, and it voluntarily integrated its student body before the 1954 Supreme Court case, Brown v. Board of Education. Martin Luther King (1929-68) nodded to the college's action in his "Letter from the Birmingham Jail," a fact the college continues to celebrate. Other Jesuit institutions desegregated later, as secular colleges and universities did.

\section{Controversy and Transformation}

The Second World War and the rise of the Soviet Union promoted a fusion of piety and American nationalism. Americans battling first the Axis powers and then international communism understood themselves to be combating godlessness and nihilism, not simply opposing a rival power or political schema. It was a view that accorded in no small measure with American Jesuits' understanding of the moment. That sense of mission and crisis elevated two quite different Jesuits to prominence: John Courtney Murray (1904-67), who called for a liberalization of the church's approach to religious diversity, and Walsh,

192 Gleason, Contending with Modernity, 235-41; Schroth, American Jesuits, 126-31.

193 Gleason, Contending with Modernity, 238-39; Schroth, American Jesuits, 128-29; George Harold Dunne, "The Sin of Segregation: The Immorality of Racial Segregation," Catholic Interracial Council of the Bishop Foery Foundation, 1945. 
who embraced domestic political conservatism and a powerful national security regime.

Walsh, long a foe of communism, argued that in order to capitalize on its geopolitical ascendance after the war, the United States must become "a city mounted on [a] foundation of moral values, adorned with dignity of human personality and rendered cohesive by acceptance of universal law." Walsh's exhortations were also more practical; he supported President Harry S. Truman's (1884-1972, in office 1945-53) plan of peacetime conscription. Some prominent Catholics, including Dennis J. Dougherty (1865-1951), cardinal of Philadelphia, opposed the plan as potentially destructive to American morals and provocative of war. Walsh, however, believed the existence of the Soviet Union constituted an emergency that legitimated the draft. Strength was needed as well as moral superiority, and that strength included atomic weaponry - even, Walsh insisted, atomic weaponry deployed preemptively. The deaths of Soviet civilians would be a painful consequence, but not one that undermined the legitimacy of the goal: preventing Soviet triumph over the United States. ${ }^{194}$

Walsh's positions drew fierce criticism, including from fellow Catholics. Jesuits also debated the proper response to a form of anti-communism rapidly gaining power: Joseph McCarthy's (1908-57) unfounded accusationslaunched against government workers, academics, artists, and others-of communist sympathies and even treason. The man who would become the infamous Senator McCarthy was educated at Marquette University and considered himself a faithful Catholic; a story, since judged apocryphal, was often repeated that Walsh himself suggested that McCarthy take up the cause of anti-communism in order to ensure his reelection. During the first two years of McCarthy's campaign against communists within the government, America gently suggested the senator was overreaching in pursuit of a worthy aim. But during the presidential campaign of 1952, McCarthy's insinuation that Democrat Adlai Stevenson (1900-65) had committed treason provoked the editor of America, Robert Hartnett, S.J. (1904-87), to turn criticism into outright condemnation. McCarthy responded that as an "ardent Catholic," he demanded an apology; when Hartnett refused, McCarthy attempted to persuade Hartnett's Jesuit superior to discipline him. That did not happen, and Hartnett, convinced McCarthy was harming the rule of law, continued to criticize his crusade. The magazine's stance provoked anger in some readers (and in some non-readers: one Catholic wrote to explain he could not cancel his subscription since he did not have one, but he hoped that others would). Others

194 McNamara, "Argument of strength justly and righteously employed," quote at 65-66. 
supported the magazine's stance. As Hartnett's editorials continued, a Catholic newspaper, The Tablet, assailed the magazine and some Jesuits also objected to his stance. Divisions over McCarthy spread to Georgetown, Santa Clara, and other Jesuit institutions. So intense was the disagreement that some New York communities agreed not to discuss the issue. Convinced that the magazine was engaging in controversy among Catholics in a way that did not accord with Ignatian expectations, America's superiors ordered Hartnett to cease his commentaries on McCarthy. Hartnett's appeal, in which he argued that such a silencing would inevitably become publicly known and would tarnish the reputation of the church in the United States, succeeded in convincing his superiors to allow him to comment on McCarthy if the good of the church required it. But the superior general in Rome, Jean-Baptiste Janssens (18891964, in office 1946-64), stepped in and ordered Hartnett to say no more on the subject. 195

The post-war era found a second Jesuit making arguments that shared Walsh's confidence in American ideals — and his ambition — but that were dramatically different in tone, audience, and effect. That Jesuit was John Courtney Murray (1904-67). Murray, a New York native educated at Boston College, believed that the Second World War had demonstrated the urgent need for cooperation among Catholics, Protestants, and Jews. Although the horrors of Nazism and fascism had discredited the anti-Semitism in which the Civiltà cattolica - and the church writ large — had dealt in recent decades, Courtney's ecumenism was not an immediately popular position: he encountered resistance both from Catholic leaders who feared a dilution of Catholic doctrine and from Protestants who believed that Catholic calls for cooperation emerged from reluctant strategy rather than sincere belief. When Murray next began to develop and share arguments that the United States' separation of church and state was a positive good, rather than simply something to be endured (a view Carroll had settled on a century and a half earlier, but which had fallen into disrepute) the Redemptorist priest Francis J. Connell (1888-1967) publicly contested Murray and privately reported his views to Rome's Holy Office. Murray continued to advance his case, including in a speech at Catholic University in 1954 during which he criticized a Vatican official. That official, Cardinal Alfredo Ottaviani (1890-1979), initiated a complaint against Murray, and within a few months, the Holy Office found four "erroneous doctrinal propositions" in Murray's thought. This was a continuation of an old argument, and for the moment, the more conservative view won the day: Rome considered pluralist

195 McDonough, Men Astutely Trained, 379-83. 
democracies at best imperfect waystations on the path to a Catholic confessional state. Murray was essentially silenced. ${ }^{196}$

Eight years later, preparations began for the Second Vatican Council. Vatican II, as it became known, met from 1962 to 1965 and resulted in changes in the liturgy, a new emphasis on the dignity of the laity, and calls for renewal and reform of religious life. The council also addressed the church's relationship with governments and other faiths. Murray had not initially been invited to participate, but when it became clear that subjects on which he had written would figure in the council's discussions, Cardinal Francis Spellman (1889-1967) of New York informed the Vatican secretary of state that bishops and theologians had expressed concern over Murray's exclusion, and recommended that he be invited to contribute. The intervention was successful, and Murray joined other Jesuits including Augustin Bea (1881-1968), Henri de Lubac (1896-1991), and Gustave Weigel (1906-64) as prominent participants in the council.

Murray prepared a memorandum for US bishops. Totalitarian states did not support religious liberty, he noted - an argument even the most conservative Catholics would not have gainsaid - and observed that the Catholic Church would have no credibility in arguing for the rights of Catholics in such states if it did not make a more general stand for religious liberty. Murray presented his case as compatible with John XXIII's (1881-1963, r.1958-63) Pacem in terris (April 11, 1963), an encyclical in which, Murray argued, the pope bade farewell to "the day of centralized, personal and paternal rule." Murray also made his case more publicly, writing in America that "the Anglo-American tradition of politics, law, and jurisprudence" would be useful to the council, and that the principles embedded in the American founding documents-individual rights and governments' obligation to protect them-were entirely compatible with the teachings of both Pius XII and John XXIII. Centuries of absolutism in Europe had obscured the fact that government was incapable of providing spiritual guidance, but the United States had preserved that principle and now it could be spread more widely. It was time, Murray insisted, to replace the confessional state as the ideal polity. Spain was the past. The United States was the future. ${ }^{197}$

As deliberations progressed, Murray crafted arguments for use during conciliar debate. His argument for religious freedom was significantly edited, its references to history and sociology trimmed. But its central claims, that the

196 Joseph A. Komonchak, "The American Contribution to Dignitatis humanae: The Role of John Courtney Murray, S.J.," U.S. Catholic Historian, special issue, "Dignitatis humanae: The Declaration of Religious Liberty, on Its Fortieth Anniversary," 24, no. 1 (2006): 2-5.

197 Komonchak, "American Contribution to Dignitatis humanae," 7-10. 
era of the Christian prince, and even the era of longing for a Christian prince, had ended and that religion would thrive in democracies whose governments arrogated no spiritual power to themselves, prevailed.

Participants in the council recognized that relations among members of different faiths were a matter of culture and theology as well as law. The council's decree on ecumenism asserted: "The restoration of unity among all Christians is one of the principal concerns of the Second Vatican Council." Under the guidance of the Jesuit Augustin Bea, the council repudiated the idea (never a church doctrine) that Jews, rather than humanity as a whole, bore responsibility for Christ's crucifixion, and it called for Jews to be understood not as a "race" but as "the chosen people of the Old Testament." Recent history had revealed the horrific consequences of anti-Semitism, not least Catholics' participation in it. But was the church also willing to repudiate its old confidence that all people were better off Christian than not? Since the Second World War, colonized peoples had sought self-determination using both peaceful and violent means; missionaries, including Jesuits, were sometimes attacked or expelled. The question had now been posed of whether missionary work was itself a form of imperialism. Karl Rahner (1904-84), a German Jesuit theologian, declared that Vatican II marked the end of the church as "an export firm, exporting to the whole world a European religion along with other elements of this supposedly superior culture and civilization." No longer did Rome claim "to know what is best everywhere in the world for the service of the Kingdom of God." The Society of Jesus had always sought congruencies in other cultures and had often been accused of too great flexibility in its proselytizing. Rahner's position, explicitly disavowing European claims to superior civilization, went beyond strategy to humility.

Vatican II; anti-colonial and anti-war movements in the United States and abroad; the 1965 Immigration Act's abolition of national origins quotas; Humanae vitae (July 25, 1968), which in its refusal to change church policy on contraception alienated some clergy and lay Catholics from the judgment of the church; growing acceptance of extramarital sex and homosexuality, the rise of liberation theology; the ongoing integration of American Catholics into the civil, political, and social life of the nation: the events of the 196os and 1970s proved transformative, often in unpredictable ways. 
While Vatican II was changing the church and cultural, political, and technological transformations were remaking the world, a new superior general was reshaping the Society. Pedro Arrupe (1907-91, in office 1965-83) was the first Basque to lead the Society since Ignatius himself. The multilingual Arrupe had been in Hiroshima when the United States dropped an atomic bomb on the city; his cosmopolitanism and deep consciousness of suffering shaped his leadership of the Society. The Society must be a force for justice on earth, Arrupe believed. As the Thirty-Second General Congregation, convened in 1974, stated it: "Our faith in Jesus Christ and our mission to proclaim the Gospel demand of us a commitment to promote justice and enter into solidarity with the voiceless and the powerless." (In 1970, Arrupe wrote to an aged Claude Heithaus, expressing gratitude for his calls for racial justice decades earlier.)

The general congregation that chose Arrupe also eagerly responded to the Second Vatican Council's call for religious orders to reform their training in accord with both their original purposes and the needs of modernity. Jesuits set out to reform the process of formation and indeed much of community life. Patrick Howell, S.J. posits that although the Society had appeared healthy in terms of numbers, with a few notable exceptions "its spirituality was stunted, its vision parochial, and its intellectual life predictably safe."198 Recalling his own novitiate, Howell observed that "the Ignatian dynamic of experiments [...], when the novice would shed the safe cocoon of the novitiate, had been lost." ${ }^{199}$ Reforms included abandoning the cassock for clerical shirts and pants, reducing the custodial nature of Jesuit formation, and ending or reducing practices such as silence during meals, changes that affected the ethos as well as the daily life of the American Society.

Howell also recalls a change he experienced as a young scholastic in the 196os: conventional "preached retreats" began to include smaller, improvisational gatherings and individual guidance. Companions and spiritual directors began to encourage Jesuits in formation to attend individually to moments or experiences in which they felt themselves moving toward God (consolation) or away (desolation); some used images and even film clips to "help reveal the divine involvement in human experience." Jesuits understood themselves to be using technology and psychology to return to the spirit of the original Exercises, which Ignatius had intended to be intense labors between an individual Jesuit and a director. Howell writes that "multiple innovations with

198 Patrick J. Howell, "The 'New' Jesuits: The Response to the Society of Jesus to Vatican II," Conversations on Jesuit Higher Education 42, no. 4 (2012); https://epublications.marquette .edu/conversations/vol42/issi/4 (accessed November 7, 2019).

199 Howell, Great Risks, loc. 491. 
the Spiritual Exercises brought the Gospels alive and fostered one's personal encounter with Christ."200

It was a fertile but profoundly unsettling time. Some, especially among the older Jesuits, believed the changes risked weakening or even destroying the Society; others celebrated them as invigorating and anti-authoritarian. Still others left the order behind. The number of Jesuits worldwide declined by between 811 and 1,037 each year during the 196os and '7os, the drop due to a combination of declining vocations, deaths, and departures from religious life. ${ }^{201}$

Jesuits who entered or chose to stay often looked forward to an expanded social ministry and embraced the need to work peacefully with and to learn from other religious traditions, an ethos Arrupe described in 1978 using the term inculturation. American provinces that in the past had understood themselves to be sending missionaries, now considered themselves to have partners - or "twins" - overseas. Rahner spoke at Jesuits' Weston theologate, offering a vision of a church humbly engaged with other religions and with all peoples of the world. ${ }^{202}$ This effort to listen to voices from other parts of the globe brought controversy when some Jesuits participated in the movement known as liberation theology. Arrupe cautioned against Marxist analysis, suggesting it was difficult to disentangle practical Marxist-inflected analysis from a subordination of all human endeavors within the realm of economics. Yet Arrupe also advocated practical collaboration with Marxists and cautioned against an anti-communism that was "nothing but means for concealing injustice."203

The new determination to remake the Society so that its members felt part of the world rather than separate from it had practical as well as spiritual and political consequences. Novitiates that had been carefully placed in rural settings were-decades after the possibility was first discussed-transplanted to cities: Oregon's Sheridan novitiate moved to Portland, the philosophate at Shrub Oak to Fordham, and the Weston philosophate and theologate to Boston

$200 \quad$ Howell, Great Risks, loc. 1385.

201 Thomas P. Gaunt, S.J., "The Changing Jesuit Geography," February 1, 2011; http://nineteen sixty-four.blogspot.com/2011/o2/changing-jesuit-geography.html (accessed November 7, 2019).

202 John W. O'Malley, S.J. Jesuits: A History from Ignatius to the Present (Laham, MD: Rowman \& Littlefield, 2014), e-book, loc. 8०\%; “Our Universal Vocation," Jesuits Worldwide; https:// jesuits.org/worldwide (accessed December 12, 2019); Howell, Great Risk, loc. 649.

203 Pedro Arrupe, "Marxism and Catechesis" (1977), Portal to Jesuit Studies; https://jesuit portal.bc.edu/research/documents/1977_arrupemarxism (accessed November 7, 2019). Originally published in Justice with Faith Today: Selected Letters and Addresses; II, ed. Jerome Aixala (St. Louis, MO: Institute of Jesuit Sources, 1980), 253-67. 
and Cambridge. Woodstock, so long and famously a world apart, moved to Union Theological Seminary in Manhattan. (Howell observes, "often enough some fundamentalist group or schismatic Catholic sect bought the former Jesuit properties," perhaps seeking the kind of separation the Jesuits now rejected. ${ }^{204}$ )

It was not just the theologates that were changing. The 196os also saw Jesuit colleges and universities creating academic senates and instituting far more robust faculty governance in decisions about curriculum and tenure. Lay advisory boards and lay trustees were also growing in authority. St. Louis University created a powerful board of trustees dominated by laymen and women in 1967. President Paul Reinert, S.J. (1910-2001) argued assertively that Jesuit higher education depended on the full participation of laypeople, whose skills and finances could do for them what "the members of the board of such institutions as Princeton, the University of Chicago, etc." had done for them. ${ }^{205}$ A writer in America wrote that boards with laypeople "more accurately reflect the sharing of responsibilities that ought to characterize the People of God."206 There was another, more immediate reason to work toward shared governance: the concern that federal and state aid might be jeopardized if Catholic higher education was under the exclusive control of clergy and women religious. In 1963, the president of the Jesuit Educational Association, Edward Rooney, S.J. (c.19oo-76), wrote that non-Catholics were already contributing to Catholic higher education and that openness was in keeping with the era's "Ecumenical Movement." ${ }^{207}$ Leaders at schools such as St. Louis, Georgetown, and Fordham became more willing to hire non-Catholic candidates with impressive credentials and research agendas. The changes evoked consternation and, in some cases, including Fordham, provoked financial crises, as new expenditures exceeded revenues. Yet the transformation continued, and Jesuit universities became home to many faculty whose purposes and publications were largely indistinguishable from those at other institutions.

In 1967, leaders in Catholic higher education created a significant declaration of principle: the Land O'Lakes Statement. Responding to the Second Vatican Council, the International Federation of Catholic Universities had recommended that regional conferences contemplate the future of Catholic higher education. At a Wisconsin site owned by Notre Dame, leaders in Catholic

\footnotetext{
204 Howell, Great Risks, loc. 1632.

205 Leahy, Adapting to America, 110.

206 Quoted in Kathleen Mahoney, Catholic Higher Education in Protestant America: The Jesuits and Harvard in the Age of the University (Baltimore: Johns Hopkins University Press, 2004), 246.

207 Quoted in Leahy, Adapting to America, 109.
} 
higher education, including a number of Jesuits, gathered and drafted a statement asserting that each institution must possess the "institutional autonomy and academic freedom [that] are essential conditions of life and growth and indeed of survival for Catholic universities as for all universities." The colleges and universities were also to remain institutions "in which Catholicism is perceptibly present and effectively operative." The Catholic university, the statement continued, "serves as the critical reflective intelligence of its society" and of the church, and the church would benefit from the university's unfettered evaluation and good counsel. ${ }^{208}$

The expansion and growing scholarly ambition of Jesuit higher education in the United States took place against a backdrop of increasing competition for Jesuits' time. Jesuits' "preferential option for the poor" meant that the long-standing emphasis on providing education in exchange for tuition became less dominant (though still central) in their work and understanding of themselves. During Arrupe's generalship, American Jesuits continued to work in education more than in other realms, but they placed a greater emphasis on educating underprivileged children and developed more ambitious scholarship programs. The number of Jesuits who worked in social ministry, while still small, rose significantly. ${ }^{209}$ In 1980, the Society began the Jesuit Refugee Service, whose mission is "to accompany, serve and advocate for the rights of refugees and other forcibly displaced persons."

The history of the Gesù parish in Philadelphia suggests some of the changes that have occurred in the late twentieth century. The church of the Gesù was constructed after the Civil War and modeled on the Gesù in Rome; gone were the days in which Jesuits such as Carroll had favored architectural styles that blended with the brick fronts of their federal-style American neighbors. As immigrants entered the United States and moved into the North Philadelphia area, the parish grew — at one point boasting twenty thousand members - and its associated school flourished. A college was founded, and in 1927, now known as St. Joseph's University, it moved to an expansive new campus. But as Catholic families left urban areas such as that surrounding the Gesù church, the parish shrank. In 1993, the parish was disestablished. The school, which had been known as St. Joseph's Preparatory, became an independent Catholic school run by Jesuits and Servants of the Immaculate Heart of Mary, and it took over what had been the Gesù church building. Now known as Gesu School, it offers priority in admission to children from moderate- and low-income families, and

\footnotetext{
208 Land O' Lakes Statement, July 23, 1967, 1, 2, 5; http://archives.nd.edu/episodes/visitors/lol/ idea.htm (accessed December 12, 2019).

209 McDonough, Men Astutely Trained, 331.
} 
the vast majority of its students are non-Catholic. Around one-third of Gesu families have an annual income below $\$ 30$,ooo. The school builds its programs on the Jesuit ethos of care for the whole person, offering extracurriculars and character formation as well as classroom teaching.

\section{Change Accelerates}

During the turbulence of the 196os and '7os, as the Society involved itself in issues of earthly justice and wellbeing, two Jesuits came to national attention in the United States because of their direct interventions in political questions. Robert Drinan (1920-2007), a Jesuit and lawyer educated at Boston College, Georgetown, and the Gregorian University in Rome, was elected to Congress in 1970 as an anti-war candidate. Drinan called for Richard Nixon's (1913-94, in office 1969-1974) impeachment after the secret bombing of Cambodia came to light and served as a delegate to the 1972 Democratic National Convention. His support for legal abortion - despite his personal opposition to the practicedrew criticism throughout his career. In 1980, when John Paul II (1920-2005, r.1978-2005) required clergy withdraw from elected office, Drinan ended his political labors.

Drinan's fame was eclipsed by a second Jesuit known for political activism outside of formal institutions: Daniel Berrigan. Berrigan initially seemed bound for life as a Jesuit teacher and poet; in 1957, after studies that included time at Woodstock College, he was appointed a professor at Le Moyne College, and the same year he won a national prize for a volume of poetry. Berrigan was drawn to liturgical reform - offering the Mass in English and facing the congregation long before Vatican II - and also to work with poor people. A posting in France introduced him to criticism of colonialism in Vietnam, and he and his brother, the Josephite priest Philip Berrigan (1923-2002), founded the Catholic Peace Fellowship. Subsequent years found Berrigan increasingly involved in antiwar alliances, both with other Catholics - including Dorothy Day and Thomas Merton (1915-68) — and with people of other faiths. A residence at Cornell left him intensely critical of academia as well as American foreign policy. In 1968, Berrigan agreed, after some reluctance, to join his brother in publicly burning draft cards at the Selective Service Office in Catonsville, Maryland. He spent time in hiding before serving a two-year prison sentence. The draft action brought Berrigan international admiration. Yet it was criticized not only by those who supported the war but also by Day and Merton, who questioned whether the destruction of property might not lead away from non-violence. (Berrigan answered that some property should not exist.) 
Berrigan at many points found himself separated literally and figuratively from his brethren. His anti-war activities, which displeased many conservative Catholics, provoked his superiors to send him for three months to Latin America. The trip seems to have been intended to move Berrigan away from overt political engagement; witnessing the poverty and authoritarian governments of Latin America, however, only deepened his conviction that he must work to promote earthly justice. At another moment, after his release from prison, Berrigan returned to his Jesuit residence to find his things in the hallway; he was told to find an apartment and bill the province. Yet Berrigan remained a Jesuit, and Arrupe visited him in prison during a trip to the United States. Later in life, he wrote that he considered leaving the Society (his brother left the priesthood to marry) but chose to remain. In the mid-1970s, he moved into a Jesuit community in Manhattan, and in his 1987 autobiography To Dwell in Peace, he referred to himself as "only of late years, folded in a Jesuit community at last." Berrigan remained in that community until it closed in 2009, and died in 2016, at the age of ninety-four, in a Jesuit care facility. His opposition to what he considered elements of a culture of death-nuclear weapons, the death penalty, abortion-never waned.

Berrigan was an extraordinary figure, representative of no one but himself. Yet his criticism of the isolation he had experienced during his formation accorded with the Society's reimagining of itself after Vatican II. Young Jesuits at Woodstock College, for so long proudly a world apart, now lived in New York City, alongside students at the Union Theological Seminary and the Jewish Theological Seminary. Students now lived in apartments rather than dormitories and were given allowances and checking accounts, rather than, as had been the custom, relying on superiors for all money.

The theory of Jesuit formation was changing; so, with equal or greater consequence, was the mathematics of it. A defining fact of Jesuits' recent history is the ongoing and dramatic decline in their numbers. In the United States and Europe, the number of men and women entering formation began to drop in the 196os and continued to do so for decades, only stabilizing - at much lower levels - in the second decade of the new century. The number of Jesuit scholastics in the United States had neared eight hundred in 1966; in 2016, the number of men at an equivalent stage of the reformed training period was sixty-six. ${ }^{210}$ Jesuits also continued to leave religious life in significant numbers, as they had begun to do in the 196os. Between 1987 and 2017, the number of

210 Georges Alsankary and Thomas Gaunt, S.J., "Jesuit Global Demographics in 2018," December 20, 2018; http://nineteensixty-four.blogspot.com/2018/12/jesuit-global-demo graphics-in-2018.html (accessed November 7, 2019); Howell, Great Risks, loc. 625. 
Jesuits in North America declined from 5,578 to 2,446. This is part of the larger story of declining religious vocations that has transformed both the landscape of American Catholicism and the experience of life in religious community. In 1965 , there were around forty-nine thousand seminarians; in 2002, there were 4,700. The number of seminaries itself dropped by more than half during the same period. Priests' average age was rising as their numbers were declining, and the same was true for sisters. ${ }^{211}$

The Society of Jesus remains the largest Catholic order, with over fifteen thousand Jesuits in 2019. It is organized into seventy-six provinces and independent regions grouped into six geographic conferences, known as assistancies. The number of Jesuits has grown in Africa and South Asia since 1987, declined slightly in the Asia Pacific region, declined significantly in Latin America, and plunged in Europe and North America. In the United States, the number of Jesuits (including priests and scholastics) dropped from about eight thousand in the mid-196os to around 5,6oo in 1982, and to around 2,10o in 2018. The number of men beginning formation now stands at around twenty per year. The average age of all Jesuits in the United States-including scholastics-is over sixty, and even the men entering formation are older than in the past. ${ }^{212}$

By the early 1970s, there were not enough young Jesuits to justify the remaining five theologates. As the cost of supporting the institutions became unsustainable, Arrupe and American Jesuits pondered which to close. Arrupe chose Woodstock, and its library was transferred to Georgetown University, where it remained under the direction of the Society and formed part of the Woodstock Theological Center until the center's closure in 2013; the library is now overseen by Georgetown. The Chicago theologate's closure was announced in 1980. Only Berkley and Weston College in Cambridge remained, each located near a thriving Jesuit university. Decades later, the theologates joined with those universities-Boston College in the east and Santa Clara in the west. Santa Clara University's Jesuit School of Theology, in Berkeley, California, offers graduate degrees as well as ecclesiastical degrees, and promotes its integration with other cultural and educational institutions in the region; the Boston College School of Theology and Ministry also offers both graduate and ecclesiastical degrees, welcomes a wide variety of students, and integrates theological studies into nursing and social work programs.

\footnotetext{
211 Alsankary and Gaunt, "Jesuit Global Demographics in 2018."

212 Gaunt, "Changing Jesuit Geography"; Gaunt, "By the Numbers: Jesuit Demography," January 9, 2015; http://nineteensixty-four.blogspot.com/2015/o1/by-numbers-jesuit-demo graphy.html (accessed November 7, 2019); and Alsankary and Gaunt, "Jesuit Global Demographics in 2018."
} 
As the Society turned to ecumenical work, care of refugees, and advocacy on behalf of the exploited and disenfranchised, Arrupe found both supporters and critics. The Thirty-Second General Congregation, which Arrupe convened in 1974, made clear he had broad and deep support from the delegates, but Jesuits were entering a period of controversy with the papacy. Paul John Paul II questioned the direction of the Society, including what he perceived to be Jesuits' significant involvement in liberation theology. When Arrupe was disabled by a stroke in 1981, he named Vincent O'Keefe, S.J. (1920-2012) vicar general. O'Keefe, an American, had served as an assistant, then as a general assistant and as counselor to Arrupe. John Paul rejected the choice of O'Keefe, instead appointing a "personal delegate," the Italian Jesuit Paolo Dezza (190199), to govern the Society during Arrupe's incapacitation. It was an extraordinary decision that caused enormous anxiety. All agreed it was prompted by the pope's mistrust of Jesuits' perceived doctrinal liberalism and their social and political engagement. Some predicted Jesuits would protest the pope's actions; other observers wondered whether a new suppression approached. Both predictions went unfulfilled. Jesuit leaders, including O'Keefe, reminded Jesuits of their vow of obedience, and John Paul II restored the Society's ability to choose a successor to Arrupe within a year. ${ }^{213}$ Jesuits selected Peter-Hans Kolvenbach (1928-2016, in office 1983-2008) as superior general while also offering Arrupe himself, incapacitated still, a sustained and thunderous ovation. ${ }^{214}$

That placid resolution to the governance crisis did not portend smooth sailing ahead. About twenty Jesuits and their supporters protested the promulgation of Humanae vitae in the Basilica of St. Peter's, in what they called a "pray in."215 More broadly, John Paul II's charismatic, centralizing papacy, with its vigorous commitment to traditional church teachings on gender and its disapproval of liberation theology, never matched the spirit of the post-Vatican II Society. Benedict XVI (1927-, r.2005-13) who succeeded John Paul in 2005, did not engage in direct conflict with the Jesuits, but his ethos as a conservative theologian did not easily accord with the Society's. When addressing the 2008 general congregation, Benedict encouraged Jesuits to "find the fullest sense of your fourth vow," obedience to the pope, and reminded them:

In the attempt to build bridges of understanding and dialogue with those who do not belong to the church or who have difficulty in accepting its positions and messages, you must loyally take charge of the church's

213 James Martin, S.J., "RIP Vincent O'Keefe, S.J.," America (July 24, 2012).

214 O'Malley, Jesuits, loc. 84\%.

215 Howells, Great Risks, loc. 1384. 
fundamental right to remain faithful to its mandate and adhere completely to the Word of God as well as to the Magisterium's charge of conserving the truth and unity of Catholic doctrine in its entirety.

Nor did American Jesuits rest easily within a national polity moving to the right. Although many Catholics remained Democrats, some-including prelates-publicly allied with evangelical Christians in ways that aligned with Republican Party positions. Jesuits, for their part, shared with many Republicans an opposition to abortion, but their emphasis on the alleviation of poverty, their rejection of the death penalty, and their sympathy for antiauthoritarian movements in Latin America meant that they would not enter in any meaningful way into a Republican-inflected alliance of Catholics and evangelical Protestants.

At the level of the individual, the Society's engagement in social justice has distanced some Jesuits from the church and given others a reason to stay. Since the dramatic events of the 196os and ' 70 , "many Jesuits," McDonough writes, "have lived in tacit dissent." They find small communities-McDonough calls them countercultures - within the Society to which to adhere, whether they be religious traditionalism, social justice, "the cultivation of a gay lifestyle, [or] involvement with non-Western religions." 216

In practical terms, most Jesuits now live with few or no brethren-a situation akin to that of missionaries in the Pimería Alta or early New France, but utterly different from the "long black lines" that characterized Jesuit American life through much of the nineteenth and twentieth centuries. Jesuit colleges and universities are now staffed in great measure by non-Jesuits, including non-Catholics. Current and former Jesuits interviewed about their lives discuss not only the loneliness that can result from such conditions but also doubts about their vocation: If laypeople and women perform these labors so well, what need is there for a Jesuit?

The Catholic Church in the United States is itself both a large and a vulnerable institution. About twenty-one percent of Americans, or about one in five adults, identify as Catholics; they are spread throughout the country (though the population is shifting to the Southwest from the Northeast and Midwest, as it once shifted from the Upper South to the Northeast). Catholics are divided more or less equally between the two major political parties, and they are racially and ethnically diverse, thanks in no small measure to immigration since the 1964 act. Six in ten are white, about one-third are Latino, and smaller

216 Peter McDonough and Eugene C. Bianchi, Passionate Uncertainty: Inside the American Jesuits (Berkeley: University of California Press, 2002), loc. 31, 37. 
percentages identify as black non-Hispanic, Asian non-Hispanic, or other. There are wealthy Catholics, poor Catholics, and everything in between. In short, Catholics are a presence in every facet of American life.

At the same time, Catholicism has seen more attrition due to changed religious beliefs than any other faith; there are more than six adults who have left the church for every convert to it. Its share of the population is dropping, from twenty-four percent in 2007 to its current twenty-one. A large number of American Catholics support significant change in the central teachings of the church: Pew reports that in one way or another, six in ten support an end to the celibate male priesthood. The church globally and in the United States has also been corroded by sexual abuse, particularly of children. The first public accounting of sexual abuse among clergy in the United States came in the mid1980 s, when three priests warned a committee of the US bishops' conference that victims of clerical abuse existed and should be treated respectfully and honestly. That same year, the National Catholic Reporter published a story and editorial on sex abuse, and three years later, the Survivors Network of Those Abused by Priests (SNAP) was founded. But sexual abuse continued, and so did prelates' failure to report allegations to the police; in innumerable cases, no one took any action at all to limit offenders' ability to harm.

In 2002, when a judge ordered Boston's Cardinal Bernard Francis Law (1931-2017) to turn over ten thousand pages of church records and the Boston Globe began an investigative series on the subject, the depth and breadth of the problem began to become clear. In subsequent years, archdioceses were revealed to have kept known pedophiles in their parishes with access to children, dioceses declared bankruptcy over payments to victims of sexual abuse, and Pope John Paul II called American cardinals to Rome to discuss the crisis. In 2011, the Oregon province of the Society (Oregon, Washington, Idaho, Montana, and Alaska) set aside $\$ 166.1$ million to settle over five hundred clergy sex abuse cases.

Jesuits, now led by Superior General Arturo Sosa (1948-, in office 2016-) find themselves part of three dramatic stories in contemporary Catholicism: a reckoning with the legacy of slaveholding and colonialism, the intensifying scandal of sexual abuse, and the papacy of Francis (1936-, r.2013-). In 2016, Jesuits' central and southern province began a project with St. Louis University designed to unearth and share the history of Jesuit slaveholding in the province. In 2017, Georgetown College hosted a liturgy of "Remembrance, Contrition, 
and Hope." In attendance were Jesuit leaders from the North American provinces, Georgetown administrators, and descendants of the people Maryland's Jesuits had first enslaved and then sold. "This isn't just a Maryland issue," stated the president of the Jesuit Conference of Canada and the United States. "In a sense, all Jesuits in the United States are descendants of those Jesuits who made the decisions to hold slaves and, in this case, sell slaves. We don't look at it as their sin; we look at it as our sin." Georgetown renamed buildings so that they honor the enslaved rather than slaveholders, and it has offered preferential admissions to descendants of those once held in bondage. Colonialism as well as slavery demands a reckoning. In 2017, Jesuits in South Dakota returned 525 acres of land, given to the Society in the 188 os, to the Rosebud Sioux.

American Jesuits' efforts to confront injustices within their own tradition has occurred during a period of increased visibility for the Society, visibility brought on by the papacy of Francis. In 2013, Pope Benedict XVI became the first pope in over six hundred years to resign. He cited diminishing physical and mental faculties; some observers also noted the toll exacted by the Catholic sex abuse scandal and the leak—by Benedict's own butler—of documents revealing infighting and corruption among the members of the papal curia. When the papal conclave chose Jorge Mario Bergoglio, archbishop of Buenos Aires, to succeed Benedict, some Jesuits felt disoriented. "We never imagined that a Jesuit could become pope. It was an impossible thing," Antonio Spadaro, S.J., a friend of the pope and editor of the Civiltà cattolica said. "We Jesuits are supposed to be at the service of the pope, not to be a pope."217

Francis's commitment to social justice and his efforts to adapt some elements of the church's presentation even as he maintained its doctrines brought a Jesuit sensibility to the office. He also declined to live in the traditional papal apartments, preferring plainer quarters in a Vatican guest house, and his creation of councils and committees strikes many observers as emerging from the Jesuit tradition. Francis's environmentalism is also consonant with American Jesuits' ethos; in response to Laudato si (May 24, 2015), Jesuit schools and universities throughout the country further augmented their engagement with sustainability.

Francis has drawn interest and affection from people outside as well as inside the church, but he has also provoked intense criticism in the United States. Although he has not changed central church teachings, including those relating to sex and gender, his shift in tone and emphasis has unsettled American

217 David Gibson, "To Understand Pope Francis, Look to the Jesuits," National Catholic Reporter (March 12, 2014); https://www.ncronline.org/news/vatican/understand-pope -francis-look-jesuits (accessed November 7, 2019). 
Catholics who saw in John Paul II and Benedict not only spiritual guides but also politically kindred — and conservative-leaders. Francis's presentation of Catholicism accords less easily with the fiscal and social conservatism that had in recent decades united many Catholics with evangelical Protestants in support of the Republican Party, and some American Catholics have felt betrayed. In the face of criticism, Spadaro, the editor of the Civiltà cattolica, has defended Francis's papacy with the same vigor earlier editors defended conservative prelates such as Pius IX and $\mathrm{X}$.

Francis's papacy cannot escape entanglement with the ongoing sexual abuse crisis, which intensified in 2018. Nor can Jesuits in the United States. In August 2018, a Pennsylvania grand jury report detailed years of sexual abuse and cover-ups committed by Catholic clergy. The report reinvigorated the soulsearching that evidence of sexual abuse had provoked in the previous decade. Jesuits in the United States confronted more directly and publicly than before their role in the sexual abuse that has corroded the Catholic Church for generations, if not longer. All of the American provinces released the names of Jesuits who had been credibly accused of sexual abuse since the 1950s. There were hundreds. The priests - most of them dead — had served in high schools, universities, and on the journal America. Fordham University issued a statement identifying and condemning nine Jesuit priests with connections to the university or preparatory school, who had been credibly accused of sexual assault. ${ }^{218}$ One Jesuit, Neil McLaughlin, was believed to have abused children for decades, with accusations coming from five different states. Jesuits were revealed to have sent known abusers to retire on Gonzaga University's campus; making that story even more horrific was the fact that the abuse of children and women committed by at least twenty such priests occurred mainly in Alaskan native villages and on Indian lands in the Pacific Northwest, and superiors in some if not all cases knew of it as it occurred. ${ }^{219}$

Francis's approval ratings among polled American Catholics dropped in the wake of the grand jury report and subsequent revelations of ongoing misconduct by prelates in the United States, Australia, and other countries. There is a growing impatience for reform and uncertainty about what that should and can mean. Many observers feel the magnitude of the crisis threatens to unravel the already loosened ties of many American Catholics to the church. Howell

218 Courtney Brogle, "Jesuit Sexual Abuse Scandal Shakes University," Fordham Observer (January 22, 2019); https://fordhamobserver.com/37437/news/jesuit-sexual-abuse-scandal -shakes-university/ (accessed November 7, 2019).

219 "Jesuits Sent Abusive Priests to Retire on Gonzaga's Campus," Emily Schwing, Aarn Sankin and Michael Corey, for Reveal, from the Center for Investigative Reporting, December 17, 2018. 
calls the scandal "a moment of humiliation, a moment of pruning." Howell is hopeful that if Jesuits accept that "carrying the crisis now is our primary ministry and not a distraction to our ministry," the clergy may be returned to the vulnerability and humility that can nurture a purified church. ${ }^{220}$

In 2019, there are around 2,100 Jesuits in the United States. The provinces now number five, soon to drop to four. There are sixty-six Jesuit parishes and twenty-two retreat centers, the latter of which host retreats for men, women, and children, some centered on elements of the liturgical calendar, others on addiction and recovery, still others on themes of the centers' own devising. Jesuits conduct considerable outreach through webpages, social media, and podcasts, as well as through the evolution of print efforts such as America and the Civiltà cattolica, which have developed ambitious digital presences. But as in the earliest days of their mission to North America, Jesuits in the United States are few in number, almost always living singly or in small groups, their lives and purposes distinct from those of the surrounding culture and not always consonant with the ethos of the church they serve. It is not clear what the future holds; throughout the long history of Jesuits in the colonies and the United States, it never has been.

\section{Bibliography}

Abé, Takao. The Jesuit Mission to New France: A New Interpretation in the Light of the Earlier Jesuit Experience in Japan. Leiden: Brill, 2011.

Anderson, Emma. The Death and Afterlife of the North American Martyrs. Cambridge, MA: Harvard University Press, 2013.

Anderson, Fred. Crucible of War: The Seven Years' War and the Fate of Empire in British North America, 1754-1766. New York: Alfred A. Knopf, 2000.

Anderson, N. John, S.J. "Parish Missions and the Jesuit Ministry." Woodstock Letters 94, no. 1 (1965):55-71.

Axtell, James. Invasion Within: The Contest of Cultures in Colonial North America. New York: Oxford University Press, 1986.

Bayne, Brandon L. "A Passionate Pacification: Sacrifice and Suffering in the Jesuit Missions of Northwestern New Spain, 1594-1767." PhD diss., Harvard Divinity School, 2012.

Bonner, Jeremy, Mary Beth Fraser Connolly, and Christopher Denny, eds. Empowering the People of God: Catholic Action before and after Vatican II. New York: Fordham University Press, 2014.

220 Howell, Great Risks, loc. $3672-73$. 
Bossy, John. The English Catholic Community, 1570-1850. New York: Oxford University Press, 1976.

Buckley, Cornelius. Nicolas Point, S.J.: His Life and Northwest Indian Chronicles. Chicago: Loyola University Press, 1989.

Buckley, Cornelius. Stephen Larigaudelle Dubuisson, S.J. (1786-1864), and the Reform of the American Jesuits. New York: University Press of America, 2013.

Burns, Robert I., S.J. The Jesuits and the Indian Wars of the Northwest. New Haven: Yale University Press, 1966.

Cerny, Karl H. "Monsignor John A. Ryan and the Social Action Department." PhD diss., Yale University, 1955 .

Chenaux, Philippe. "Father Włodzimierz Ledóchowski (1866-1942): Driving Force behind Papal Anti-communism during the Interwar Period." Journal of Jesuit Studies 5, no. 1 (2018): 54-70.

Ciani, John L. "Across a Wide Ocean: Salvatore Maria Brandi, S.J., and the Civiltà cattolica from Americanism to Modernism, 1891-1914." PhD diss., University of Virginia, 1992.

Clossey, Luke. Salvation and Globalization in the Early Jesuit Missions. New York: Cambridge University Press, 2008.

Connolly, John. "Father John McElroy, S.J.: 'First' Catholic Chaplain of the United States Army." Clogher Record 20, no. 3 (2011): 535-40.

Coppa, Frank J. "The Hidden Encyclical of Pius XI against Racism and Anti-Semitism Uncovered: Once Again!" Catholic Historical Review 84, no. 1 (1998): 63-72.

Curran, Robert Emmett. The Bicentennial History of Georgetown University: From Academy to University, 1789-1889. Washington, DC: Catholic University of America Press, 1993.

Curran, Robert Emmett. "Jesuit Colleges and the Civil War." Conversations on Jesuit Higher Education 45 (2014): 1-13.

Curran, Robert Emmett. Papist Devils: Catholics in British America, 1574-1783. Washington, DC: Catholic University of America Press, 2014.

Curran, Robert Emmett. Shaping American Catholicism: Maryland and New York, 18051915. Washington, DC: Catholic University of America Press, 2012.

Dahl, David Lebovitch. "The Anti-Semitism of the Italian Catholics and Nationalism: 'The Jew' and 'the Honest Italy' in the rhetoric of La Civiltà cattolica during the Risorgimento." Modern Italy 17, no. 1 (2012): 1-14.

Dahl, David Lebovitch. "The Anti-Semitism of La Civiltà cattolica Revisited." In "The Tragic Couple": Encounters between Jews and Jesuits, edited by James Bernauer and Robert A. Maryks, 217-31. Leiden: Brill, 2014.

De Smet, Pierre-Jean. Life, Letters, and Travels of Father Pierre-Jean de Smet, S.J., 1801-1873. New York: F. P. Harper, 1904. 
Duffy, Joseph P. "To Love and Serve: World War II Chaplains of the New England Province of Jesuits." New England Province History 5 (2014): 1-94.

Fisher, Linford. The Indian Great Awakening: Religion and the Shaping of Native Cultures in Early America. New York: Oxford University Press, 2012.

Gallagher, Charles R. "Correct and Christian': American Jesuit Support of Father Charles Coughlin's Anti-Semitism, 1935-38." In "The Tragic Couple”: Encounters between Jews and Jesuits, edited by James Bernauer and Robert A. Maryks, 295-315. Leiden: Brill, 2014.

Gallagher, Charles R. "Decentering American Jesuit Anti-communism: John LaFarge's United Front Strategy, 1934-39." Journal of Jesuit Studies 5, no. 1 (2018): 97-121.

Gjerde, Jon. Catholicism and the Shaping of Nineteenth-Century America. Edited by S. Deborah Kang. New York: Cambridge University Press, 2011.

Gleason, Philip. "American Catholic Higher Education: A Historical Perspective." In The Shape of Catholic Higher Education, edited by Robert Hassenger, 15-53. Chicago: University of Chicago Press, 1967.

Gleason, Philip. Contending with Modernity: Catholic Higher Education in the Twentieth Century. New York: Oxford University Press, 1995.

Gleason, Philip. "The First Century of Jesuit Higher Education in America." U.S. Catholic Historian 25, no. 2 (2007): 37-52.

Greco, Ernest. "Popes, Catholics, and Jews." In Catholicism and Historical Narrative: A Catholic Engagement with Historical Scholarship, edited by Kevin Schmiesing, 189-206. New York: Rowman \& Littlefield, 2014.

Greer, Allan. "Introduction." In The Jesuit Relations: Natives and Missionaries in Seventeenth-Century North America, edited by Allan Greer, 1-19. Boston: Bedford/ St. Martin's, 2000.

Greer, Allan. Mohawk Saint: Catherine Tekakwitha and the Jesuits. New York: Oxford University Press, 2006.

Hanley, Thomas O'Brien, ed. The John Carroll Papers. Notre Dame, IN: University of Notre Dame Press, 1976.

Hayne, David M. "Charlevoix, Pierre-François-Xavier De." In Dictionary of Canadian Biography. Vol. 3. Toronto: University of Toronto/Université Laval, 2003-); http:// www.biographi.ca/en/bio/charlevoix_pierre_francois_xavier_de_3E.html (accessed November 7,2019 ).

Hennessey, James. American Catholics: A History of the Roman Catholic Community in the United States. New York: Oxford University Press, 1983.

Houliston, Victor. Catholic Resistance in Elizabethan England: Robert Persons's Jesuit Polemic, 1580-1610. Aldershot: Ashgate, 2007.

Howell, Patrick J. Great Risks Had to Be Taken: The Jesuit Response to the Second Vatican Council, 1958-2018. n.p.: Cascade Books, 2019. 
Howell, Patrick J. “The 'New' Jesuits: The Response to the Society of Jesus to Vatican II." Conversations on Jesuit Higher Education 42, no. 4 (2012); https://epublications .marquette.edu/conversations/vol42/iss1/4 (accessed November 7, 2019).

Kino, Eusebio Francisco. Kino's Biography of Francisco Javier Saeta, S.J. St. Louis, MO: St. Louis University, 1971.

Komonchak, Joseph A. "The American Contribution to Dignitatis humanae: The Role of John Courtney Murray, S.J." U.S. Catholic Historian, special issue, "Dignitatis humanae: The Declaration of Religious Liberty, on Its Fortieth Anniversary," 24, no. 1 (2006): 2-5.

Kuzniewski, Anthony J. "Francis Dzierozynski and the Jesuit Restoration in the United States." Catholic Historical Review 78, no. 1 (1992): 51-73.

Kuzniewski, Anthony J. Thy Honored Name: A History of the College of the Holy Cross, 1843-1994. Washington, DC: Catholic University of America Press, 2017.

Lappas, Thomas J. "A Victim of His Own Love: Sébastien Racle, Native Americans, and Religious Politics in Eighteenth-Century New France." PhD diss., Indiana University, 2003 .

Leahy, William P., S.J. Adapting to America: Catholics, Jesuits, and Higher Education in the Twentieth Century. Washington, DC: Georgetown University Press, 1991.

Marie, Blanche. "The Catholic Church in Colonial Pennsylvania." Pennsylvania History 3, no. 4 (1936): 240-52.

Martin, James, S.J. “Reviving the Sacred Heart.” America Magazine (June 15, 2012).

Martin, James, S.J. “RIP Vincent O’Keefe, S.J.” America (July 24, 2012).

Maxwell, Kenneth. "The Spark: Pombal, the Amazon, and the Jesuits." Portuguese Studies 17 (2001): 168-83.

McCoog, Thomas M., S.J. "Construing Martyrdom in the English Catholic Community, 1582-1602." In Catholics and the "Protestant Nation": Religious Politics and Identity in Early Modern England, edited by Ethan Shagan, 95-127. Manchester: Manchester University Press, 2005.

McDonough, Peter. Men Astutely Trained: A History of the Jesuits in the American Century. New York: Simon \& Schuster, 2008.

McGreevy, John. American Jesuits and the World: How an Embattled Religious Order Made Modern Catholicism Global. Princeton: Princeton University Press, 2016.

McGuinness, Margaret. Neighbors and Missionaries: A History of the Sisters of Our Lady of Christian Doctrine. New York: Fordham University Press, 2012.

McGuinness, Margaret. "Why Relationships Matter: Sisters, Bishops, and the History of Catholicism in the United States." Catholic Historical Review 110, no. 2 (2014): 219-42.

McKevitt, Gerald, S.J. "The Art of Conversion: Jesuits and Flatheads in NineteenthCentury Montana." U.S. Catholic Historian 12, no. 4 (1994): 49-64. 
McKevitt, Gerald, S.J. Brokers of Culture: Italian Jesuits in the American West, 1848-1919. Stanford, CA: Stanford University Press, 2007.

McKevitt, Gerald, S.J. "Northwest Indian Evangelization by European Jesuits, 1841-19o9." Catholic Historical Review 91, no. 4 (2005): 688-713.

McNamara, Patrick J. “The argument of strength justly and righteously employed': Edmund A. Walsh, Catholic Anticommunism, and American Foreign Policy, 1945-52." U.S. Catholic Historian 2, no. 4 (2004): 58-62.

McShane, Joseph M. “The church is not for the cells and the caves': The Working-Class Spirituality of the Jesuit Labor Priests." U.S. Catholic Historian 9, no. 3 (1990): 289-92. McShane, Joseph M. "Sufficiently Radical": Catholicism, Progressivism, and the Bishops' Program of 1919. Washington, DC: Catholic University of America Press, 1986.

McShea, Bronwen. Apostles of Empire: The Jesuits and New France. Lincoln, NE: University of Nebraska Press, 2019.

Meehan, John, S.J., and Jacques Monet, S.J. "The Restoration in Canada: An Enduring Patrimony." In Jesuit Survival and Restoration: A Global History, 1773-1900, edited by Robert A. Maryks and Jonathan Wright, 386-98. Leiden: Brill, 2015.

Mills, Kenneth, and Anthony Grafton, eds. Conversion: Old Worlds and New. Rochester, NY: University of Rochester Press, 2003.

Mörner, Magnus. "The Expulsion of the Jesuits from Spain and Spanish America in 1767 in Light of Eighteenth-Century Regalism." Americas 23, no. 2 (2004): 156-64.

Morris, Charles R. "The First Fifty Years: The Emergence of a Catholic Voice." America (April 13, 2009).

Morrissey, Robert. Empire by Collaboration: Indians, Colonists, and Governments in Colonial Illinois Country. Philadelphia: University of Pennsylvania Press, 2015.

Morrissey, Robert. "Kaskaskia Social Network: Kinship and Assimilation in the French-Illinois Borderlands, 1695-1735." William and Mary Quarterly 70, no. 1 (2013): 103-46.

Murphy, Thomas, S.J. Jesuit Slaveholding in Maryland, 1717-1838. New York: Routledge, 2001.

Nelson, Eric. The Jesuits and the Monarchy: Catholic Reform and Political Authority in France (1590-1615). New York: Routledge, 2005.

O'Brien, David J. Isaac Hecker: An American Catholic. New York: Paulist Press, 1992.

O'Brien, John J. George G. Higgins and the Quest for Worker Justice: The Evolution of Catholic Social Thought in America. New York: Sheed \& Ward, 2004.

O’Brien, William P., S.J. “Claude La Colombière (1641-82), Marguerite-Marie Alacoque (1647-9o), and Devotion to the Sacred Heart." In A Companion to Jesuit Mysticism, edited by Robert A. Maryks, 166-92. Leiden: Brill, 2017.

O’Donnell, Catherine. Elizabeth Seton: American Saint. Ithaca, NY: Cornell University Press, 2018. 
O’Donnell, Catherine. "John Carroll and the Origins of an American Catholic Church, 1783-1815." William and Mary Quarterly 68, no. 1 (2011): 101-26.

O'Malley, John W., S.J. "Some Distinctive Characteristics of Jesuit Spirituality in the Sixteenth Century." In Jesuit Spirituality: A Now and Future Resource, edited by John W. O'Malley, S.J., Vincent T. O'Keefe, S.J., and John W. Padberg, S.J. Chicago: Loyola University Press, 1990.

Papenfuse, Eric. The Evils of Necessity: Robert Goodloe Harper and the Moral Dilemma of Slavery. Philadelphia: American Philosophical Society, 1997.

Pasquier, Michael. Fathers on the Frontier: French Missionaries and the Roman Catholic Priesthood in the United States, 1789-1870. New York: Oxford University Press, 2010.

Pasquier, Michael. "Though their skin remains brown, I hope their souls will soon be white': Slavery, French Missionaries, and the Roman Catholic Priesthood in the American South, 1789-1865." Church History 77, no. 2 (2008): 337-70.

Polzer, Charles W., Thomas H. Naylor, Thomas E. Sheridan, and Diana Hadley, eds. Jesuit Missions of Northern Mexico. New York: Taylor \& Francis, 1991.

Poulson, Susan L., and Loretta Pierfedeici Higgins. "Gender, Coeducation, and the Transformation of Catholic Identity in American Catholic Higher Education." Catholic Historical Review 89, no. 3 (2003): 489-510.

Pyne, Tricia. "The Maryland Catholic Community, 16o9-1775: A Study in Culture, Region, and Church." PhD diss., Catholic University of America, 1996.

Pyne, Tricia. "Ritual and Practice in the Maryland Catholic Community, 1634-1776." U.S. Catholic Historian 26, no. 2 (2008): 17-46.

Pyne, Tricia. "The Politics of Identity in Eighteenth-Century British America: Catholic Perceptions of Their Role in Colonial Society." U.S. Catholic Historian 15, no. 2 (1997): 1-14.

Radding, Cynthia. Wandering Peoples: Colonialism, Ethnic Spaces, and Ecological Frontiers in Northwestern Mexico, 1700-1850. Durham, NC: Duke University Press, 1997.

Reff, Daniel T. Disease, Depopulation, and Culture Change in Northwestern New Spain, 1518-1764. Salt Lake City: University of Utah Press, 1991.

Richter, Daniel. "Iroquois versus Iroquois: Jesuit Missions and Christianity in Village Politics, 1642-1686." Ethnohistory 32, no. 1 (1985): 1-16.

Richter, Daniel. The Ordeal of the Longhouse: The Peoples of the Iroquois League in the Era of European Colonization. Chapel Hill, NC: University of North Carolina Press, 1992.

Romero, Jacqueline. "By the labors of our hands': An Analysis of Labor, Gender, and the Sisters of Charity in Kentucky and Ohio, 1812-1852." PhD diss., Arizona State University, 2019.

Ronda, James P. “We are well as we are': An Indian Critique of Seventeenth-Century Christian Missions." William and Mary Quarterly 34, no. 1 (1977): 66-82. 
Schrems, Suzanne H. "The Northern Cheyennes and the Fight for Cultural Sovereignty: The Notes of Father Aloysius Van der Velden, S.J." Montana: The Magazine of Western History 45, no. 2 (1995): 23-29.

Schroth, Raymond. "Death and Resurrection: The Suppression of the Jesuits in North America." American Catholic Studies 128, no. 1 (2017): 51-66.

Scorza, Kathleen. "False Emissaries: The Jesuits among the Piscataways in Early Colonial Maryland, 1634-1648." MA thesis, Wellesley College, 2007.

Shelley, Thomas J. Fordham: A History of the Jesuit University of New York; 1841-2003. New York: Fordham University Press, 2016.

Sommerville, Johann P. "Papalist Political Thought and the Controversy over the Jacobean Oath of Allegiance." In Catholics and the "Protestant Nation": Religious Politics and Identity in Early Modern England, edited by Ethan Shagan, 162-84. Manchester: Manchester University Press, 2005.

Southern, David W. John LaFarge and the Limits of Catholic Interracialism, 1911-1963. Baton Rouge, LA: Louisiana State University Press, 1996.

Sutto, Antoinette. "Lord Baltimore, the Society of Jesus, and Caroline Absolutism in Maryland, 1630-1645." Journal of British Studies 48, no. 3 (2009): 631-52.

Trythall, Marisa P. "Russia's misfortune offers humanitarians a splendid opportunity': Jesuits, Communism, and the Russian Famine." Journal of Jesuit Studies 5, no. 1 (2018): 71-96.

White, Andrew, S.J. "A Brief Relation of the Voyage unto Maryland by Father Andrew White, 1634." In Narratives of Early Maryland, 1633-1684, edited by Clayton Colman Hall, 29-45. New York: Charles Scribner's Sons, 1910.

Yacovazzi, Cassandra L. Escaped Nuns: True Womanhood and the Campaign against Convents in Antebellum America. New York: Oxford University Press, 2018. 